\title{
Die Bedeutung \\ der Landschaftsstruktur für die Bienendiversität und Bestäubung auf unterschiedlichen räumlichen Skalen
}

\author{
Dissertation \\ zur Erlangung des Doktorgrades \\ der Fakultät für Agrarwissenschaften \\ der Georg-August-Universität Göttingen
}

vorgelegt von

Christof Bürger

geboren in Hildesheim

Göttingen, Juli 2004 
1. Referent: Prof. Dr. Teja Tscharntke

2. Korreferent: Prof. Dr. Stefan Vidal

Tag der mündlichen Prüfung: 15. Juli 2004 


\section{Inhaltsverzeichnis}

DIE BEDEUTUNG DER LANDSCHAFTSSTRUKTUR FÜR DIE

BIENENDIVERSITÄT UND BESTÄUBUNG AUF UNTERSCHIEDLICHEN

RÄUMLICHEN SKALEN. EIN ÜBERBLICK

Einleitung

$\begin{array}{ll}\text { Fragestellungen } & 8\end{array}$

Untersuchungsregion, Landschaftsausschnitte und Flächenauswahl 10

$\begin{array}{ll}\text { Habitatkartierung } & 10\end{array}$

Bestäubergruppen und Fruchtansatz $\quad 12$

$\begin{array}{ll}\text { Ergebnisse } & 12\end{array}$

$\begin{array}{ll}\text { Schlussfolgerungen } & 14\end{array}$

$\begin{array}{ll}\text { Literatur } & 15\end{array}$

IST DIE BESTÄUBUNG IN ZUKUNFT NOCH GESICHERT? 19

Wild- und Honigbienen werden weniger $\quad 19$

Imkereikataster im Jahr 2002 erstellt $\quad 20$

Zukunftsszenarien für 2022 - Bestäubungslücke wächst 21

Bienenstände sind nicht gleichmässig verteilt $\quad 24$

Imkerschaft stärken, Wildbienen fördern $\quad 24$

SPECIES RICHNESS OF TRAP-NESTING BEES AND WASPS ON FALLOWS

AND OILSEED RAPE FIELDS IN A GRADIENT OF LANDSCAPES COMPLEXITY

$\begin{array}{ll}\text { Abstract } & 25\end{array}$

$\begin{array}{ll}\text { Introduction } & 26\end{array}$

$\begin{array}{ll}\text { Material and Methods } & 27\end{array}$

$\begin{array}{lr}\text { Results } & 29\end{array}$

$\begin{array}{ll}\text { Discussion } & 33\end{array}$

$\begin{array}{ll}\text { Acknoledgements } & 34\end{array}$ 
Abstract

Introduction

Material and methods

Results

Discussion

Acknoledgements

References

POSSIBLE EFFECTS OF LANDSCAPE CONTEXT AND POLLINATOR DENSITIES ON YIELD OF OILSEED RAPE

Abstract

Introduction

Material and methods

Results

Discussion

Acknowledgements

References

WIND AND BEE POLLINATION OF OILSEED RAPE IN SIMPLE AND COMPLEX LANDSCAPES

Abstract

Introduction 79

Material and methods

Results

Discussion 86

Acknoledgements 88

References 88 
SUMMARY 91

ZUSAMMENFASSUNG 94

DANKSAGUNG 97

PUBLIKATIONEN 98

LEBENSLAUF 99 


\section{Die Bedeutung der Landschaftsstruktur für die Bienendiversität und Bestäubung auf unterschiedlichen räumlichen Skalen. Ein Überblick}

\section{EINLEITUNG}

In geschichtlicher Zeit haben immer wieder tiefgreifende Landschaftswandel und Strukturveränderungen stattgefunden. In den letzten Jahrzehnten konnte die Zerstörung und Fragmentierung zusammenhängender Lebensräume durch menschliche Aktivitäten in einem bis dahin nicht beobachteten und mit natürlichen Prozessen nicht vergleichbaren Ausmaß festgestellt werden (Antrop 2000).

Die Folgen von Habitatfragmentierung und veränderter Landschaftsstruktur für die Artenvielfalt und Stabilität von Ökosystemen sind ein aktueller Gegenstand ökologischer Forschung (z.B. Kleyer et al. 1996, Hanski 1999, Schlatter 2000). Die Landschaftsstruktur und die Fragmentierung geeigneter Habitate stellen wichtige Parameter dar, um Landschaften auf ihre ökologische Bedeutung hin zu untersuchen und Aussagen über ihre ökologische Funktionalität erhalten zu können (Kaveira \& Wennergren 1995, Gustafson 1998). Wichtige ökologische Funktionen wie die Bestäubung von Pflanzen oder die Regulation von Schädlingen durch ihre Gegenspieler können durch die Zerstörung naturnaher Lebensräume verloren gehen (Rathcke \& Jules 1993, Steffan-Dewenter \& Tscharntke 1999, Thies \& Tscharntke 1999). Dabei kommt es mit zunehmender Fragmentierung eines Lebensraumes zu immer kleineren Einzelpopulationen, die langfristig nicht überleben können (Bierregard et al. 1992, Hanski 1997). Die Verkleinerung von Populationen gefährdet insbesondere Arten höher trophischer Ebenen, Arten mit spezialisierten Nahrungs- oder Habitatansprüchen, Arten mit geringer Ausbreitungsfähigkeit, seltene Arten und Arten mit hoher Populationsvariabilität (Kruess \& Tscharntke 1994).

Eine Landschaft besitzt durch die Zusammensetzung und Anordnung einzelner Landschaftselemente ein eigenes, charakteristisches Gefüge, über das sie identifiziert und beschrieben werden kann (Hulshoff 1995, Li \& Archer 1997). Bei der Bewertung der Funktionalität einer Landschaft wird von der Struktur der Landschaft auf die Ökosystemfunktion geschlossen. Die Methoden der modernen Informationsverarbeitung, vor allem der Einsatz der Geographischen Inforationssysteme stellen ein wichtiges Hilfsmittel 
dar, um vergleichbare Indizes landschaftlicher Strukturveränderungen sowohl in räumlicher als auch zeitlicher Hinsicht zu gewinnen.

In den letzten Jahren erfolgte eine intensive Beschäftigung mit Landschaftsstrukturparametern. Geo-Informations-Systeme und die zunehmend verfügbaren Fernerkundungsdaten, beispielsweise aus Landsat-TM Bildern oder ATKIS-Daten, bieten eine Vielzahl von Möglichkeiten, um Landschaften und ihre Struktur in größeren Dimensionen zu erfassen (Walz 1998). Somit können Parameter wie Landschaftsdiversität und -heterogenität einfacher und vor allen standardisiert erhoben und bewertet werden.

Jedoch besteht noch großer Forschungsbedarf im Bezug auf die Erfassung der Landschaftsstruktur und den Einsatz unterschiedlicher Parameter, da einerseits oftmals unterschiedliche Datengrundlagen benutzt werden (Raster- oder Vektordaten unterschiedlicher Auflösung) und andererseits noch unklar ist, welche Landschaftsstrukturparameter für ökologische Systeme relevant sind (Blaschke 1999, Blaschke \& Petch 1999). So ist die räumliche Heterogenität nicht statisch, sondern dynamisch zu sehen; Landschaften können demnach als „shifting mosaics“ bezeichnet werden (Borman \& Likens 1979), während Ökosysteme durch Dynamik, Störung und Wandel charakterisiert sind (Huston 1979). Vor allem der Betrachtungsmaßstab ist ein bedeutender Aspekt der Heterogenität (Wiens 1989). So können bei höherer Auflösung kleinere Objekte erfasst und detailliert beschrieben und berücksichtig werden, die bei kleiner werdenden Maßstäben jedoch einer Generalisierung unterliegen. So beeinflussen zwei Faktoren die Kennzeichnung der Heterogenität: 1. Datenformat und Auflösung (Vektor- oder Rasterdaten; kleinste, kartierte Einheit; Pixel Größe) und 2. bei vorhandenem Kartenmaterial die Aktualität der Daten. Aber nicht nur Objekte in Form von Flächen können mit GeoInformationsSystemen analysiert werden, sondern auch „Punktdaten“, die leicht zu erheben sind. Aus solchen Daten lassen sich mit relativ geringem Aufwand Modelle erstellen und räumliche Muster generieren (Davis et al. 2000).

Umweltgerechte Landnutzung erfordert neben der Produktion von Nahrungsmitteln auch den Schutz und die Entwicklung von Umweltgütern. Die Nachhaltigkeit der Landnutzung orientiert sich dabei nicht nur an dem Erhalt der Biodiversität sondern auch an der Intaktheit ökologischer Funktionen. Bestäubung ist eine wichtige, kostenlos bereitgestellte Ökosystemfunktion von großer ökonomischer und ökologischer Bedeutung (Allen-Wardell et al. 1998, Kearns et al. 1998). Der Erhalt dieser Natur-Leistung hängt von einer ausreichenden Diversität und Dichte von Bestäubern, d.h. wildlebender Bienen sowie der Verteilung imkerlich genutzter Honigbienenvölker ab. Die Zerstörung naturnaher Lebensräume hat auf 
Landschaftsebene zu einem gravierenden Rückgang der Wildbienen geführt (Westrich 1989). Gleichzeitig nimmt seit geraumer Zeit die Zahl der von Imkern gehaltenen Völker ab (Bienefeld 1996). Als Hauptursachen gelten ein zu geringes Nahrungsangebot in intensiv landwirtschaftlich genutzten Regionen und Völkerverluste durch verstärkt auftretende Bienenkrankheiten. Die flächendeckende Gewährleistung einer ausreichenden Bestäubung ist damit gefährdet. Dieser Sachverhalt wird in Kapitel 2 dieser Arbeit berücksichtigt.

Bisherige Forschungsergebnisse zeigen, dass isolierte Pflanzenpopulationen einen verminderten Fruchtansatz erzielen (Steffan-Dewenter \& Tscharntke 1999) und dass in reich strukturierten Landschaften eine erhöhte Wildbienenabundanz und- diversität auftritt (SteffanDewenter et al. 2001). In wieweit die umgebende Landschaft in Agrarräumen einen Einfluss auf Wildbienenlebensgemeinschaften hat, wurde in Kapitel 3 und 4 untersucht.

Bestäubung besitzt aber auch einen großen ökonomischen Einfluss. Viele der Kulturpflanzen (Raps, Obstbäume etc.) sind auf Bestäubung durch Insekten angewiesen. Studien konnten belegen, dass in vielen Fällen ein höher Frucht- bzw. Samenansatz bei höherer Abundanz blütenbesuchender Insekten erzielt wird und dass Kulturpflanzen in strukturarmen Landschaften einen verminderten Fruchtansatz erzielen (z.B. Kremen et al. 2002). Folglich sind Aussagen zum Vorkommen von Bestäubern in Abhängigkeit von der Landschaftsstruktur sowie die Abschätzung möglicher Ertragsverluste in der Landwirtschaft von großer praktischer Relevanz. In den Kapiteln 5+6 wurde dieser Themenkomplex auf den Fruchtansatz von Raps (Brassica napus L.) hin untersucht.

\section{FRAGESTELLUNGEN}

In der vorliegenden Arbeit sollte der Frage nachgegangen werden, ob und inwieweit die Bestäubung als "Gratisleistung der Natur" in ausgeräumten Agrarlandschaften noch gewährleistet ist und wie diese für die Zukunft gesichert werden kann. Zur Umsetzung dieser Fragestellung wurden ökologische Freilanddaten in ein Geoinformationssystem (GIS) integriert und diese mit Daten zur Landnutzung des Amtlichen TopographischKartographischen Informationssystems (ATKIS) und Daten einer Biotopkartierung verknüpft. Weiterhin wurden Daten eines selbst erstellten Imkereikatasters mit in die Auswertung einbezogen.

Für den Landkreis Göttingen wurde die räumliche Verteilung der Artenvielfalt und Abundanz von Wildbienen und Honigbienen und der regionale Rückgang bei den Bestäubungsleistungen in einem Landschaftsstrukturgradient untersucht. Folgende Teilziele wurden verfolgt: 
(A) Erfassung der Landnutzung in einem Gradienten von strukturarmen bis strukturreichen Landschaftsausschnitten; (B) Aufbau eines GIS-gestützten dynamischen Imkereikatasters für den Landkreis Göttingen (1) zur Erfassung der Honigbienendichten im Hinblick auf Bestäubungseffekte und (2) zur praxisrelevanten Verbesserung der Krankheitsbekämpfung und der Trachtausnutzung für diesen landwirtschaftlichen Erwerbszweig. (Kapitel 2); (C) Erfassung von Wildbienenlebensgemeinschaften in unterschiedlich strukturierten Agrarlandschaften (Kapitel 3+4); (D) Erfassung der Bestäubung von Winterraps (Brassica napus L.) (Kapitel 5+6); (E) Abschätzung des Bestäubungspotentials in agrarisch genutzten Räumen des Landkreises Göttingen.

Zum Erreichen dieser Teilziele wurden folgende Fragestellungen bearbeitet:

\section{Imkereikataster (Kapitel 2)}

- Welche Verteilungsmuster sind bei den imkerlichen Bienenständen zu erkennen?

- Kann im Landkreis Göttingen durch Honigbienen eine ausreichende Bestäubung auf Dauer gewährleistet werden (Szenario: Entwicklung in 20 Jahren)?

\section{Lokale Wildbienen- und Honigbienenabundanzen in Abhängigkeit von der umgebenden Landschaft (Kapitel 3+4)}

- Welchen Einfluss haben lokale (Habitat) und regionale Faktoren (Landschaftskontext) auf die Diversität und Abundanz von Wildbienen?

- Auf welchen räumlichen Skalen lassen sich diese Muster erklären?

\section{Fruchtansatz in unterschiedlich strukturierten Landschaften (Kapitel 5+6)}

- Kann die Bestäubung und damit der Ernteerfolg in Bezug auf die Anbauprodukte und den Honigertrag durch eine bessere Verteilung der Bienenstände gesteigert werden?

- Besteht ein erhöhter Fruchtansatz an Raps in solchen Gegenden, in denen eine hohe Bestäuberdichte vorhanden ist?

- Durch welche Faktoren wird das Bestäubungssystem im Raps beeinflusst (Wind - und Insektenbestäubung)? 


\section{UNTERSUCHUNGSREGION， LANDSCHAFTSAUSSCHNITTE UND FLÄCHENAUSWAHL}

Das Untersuchungsgebiet erstreckte sich über den gesamten Landkreis Göttingen. Es wurden 18 Teiluntersuchungsgebiete ausgewählt, die einen Radius von maximal $3 \mathrm{~km}$ aufweisen (Abb. 1). Diese Untersuchungsflächen deckten einen Gradienten von strukturarmen bzw. ausgeräumten bis strukturreichen Landschaftsausschnitten ab. Als Landschaftsmittelpunkt fungierte eine Ackerbrache im Zentrum jeder Untersuchungslandschaft. Als weitere Untersuchungsflächen wurden für das Jahr 2001 und 2002 Rapsfelder in unmittelbarer Nähe (Entfernung $<250 \mathrm{~m}$ ) zur Ackerbrache ausgewählt. In Radien von 250 bis 3000m um die jeweiligen Standorte wurden Indizes zur Landschaftsstruktur erhoben.

\section{HABITATKARTIERUNG}

\section{Erfassung und Quantifizierung der Landschaftsstruktur}

Mit Hilfe von Geo-Informationssystemen können Parameter der Landschaftsstruktur effizient quantifiziert werden (Riitters et al. 1995, Walz 1998, Gasper \& Menz 1999, Bürger 2000, Conradi 2000, PATCH Analyst 2000). Somit können vorhandene landschaftsökologische Daten in Relation zu berechneten Landschaftsparametern gesetzt und neue Aspekte und Aussagen im Bereich der Landschaftsökologie erschlossen werden.

Neben der Erfassung der Landnutzung (Biotoptypenkartierung) innerhalb der einzelnen Untersuchungsgebiete wurden Parameter zur Habitatdiversität und der Landschaftsstruktur bestimmt. Insgesamt wurden 27 verschiedene Biotoptypen in der Kartierung ausgewiesen (in Anlehnung an Drachenfels 1994; Abb. 2), die in annuelle und perennierende Habitate unterteilt wurden. 


\section{Übersicht Untersuchungsgebiet LK Göttingen}

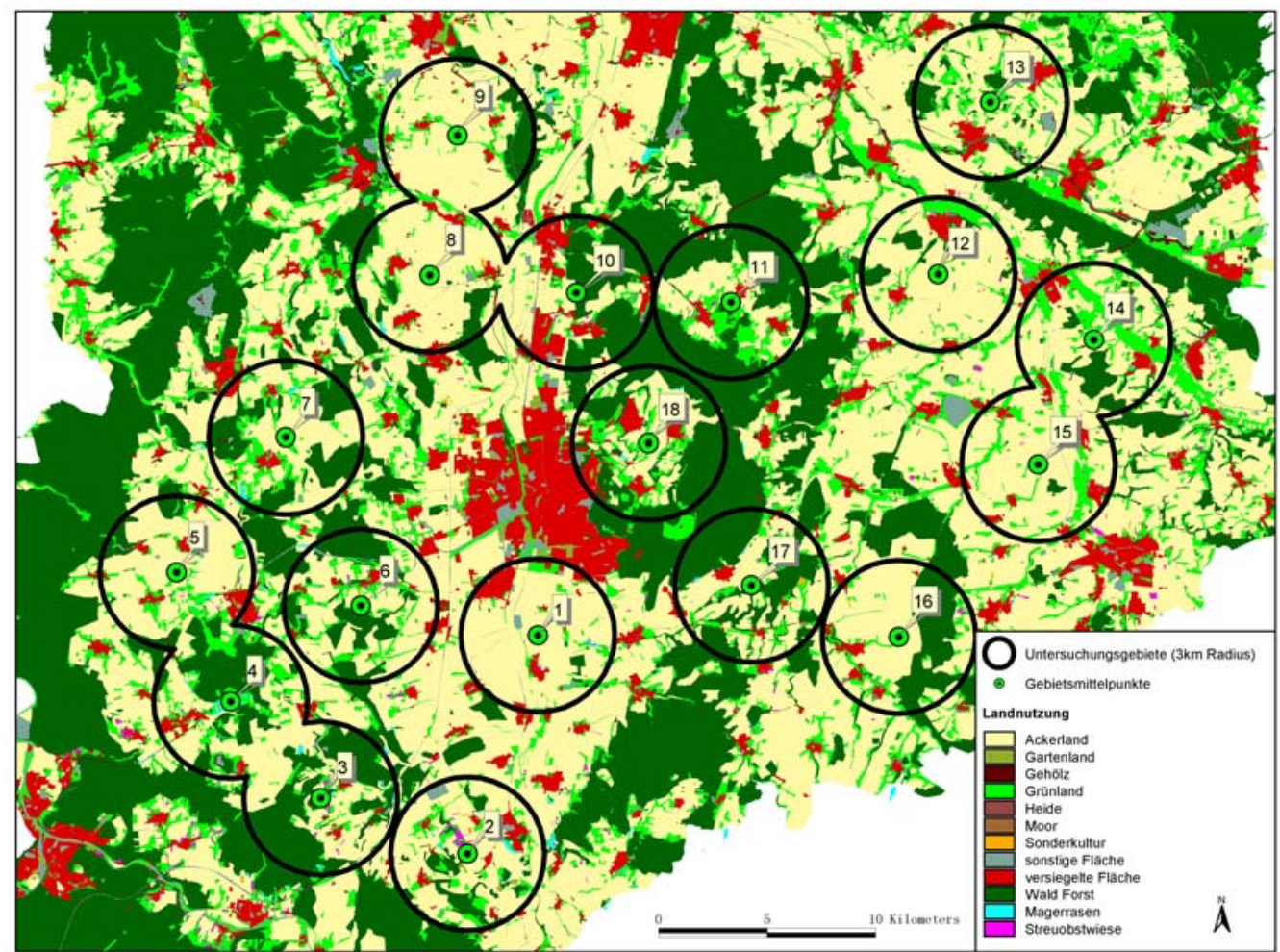

Abb. 1: Untersuchungsregion im Landkreis Göttingen mit 18 unterschiedlich strukturierten Landschaften

\section{Biotopkartierung}

(Bsp.:Landschaft 01 Reinshof / sdl. von Göttingen)
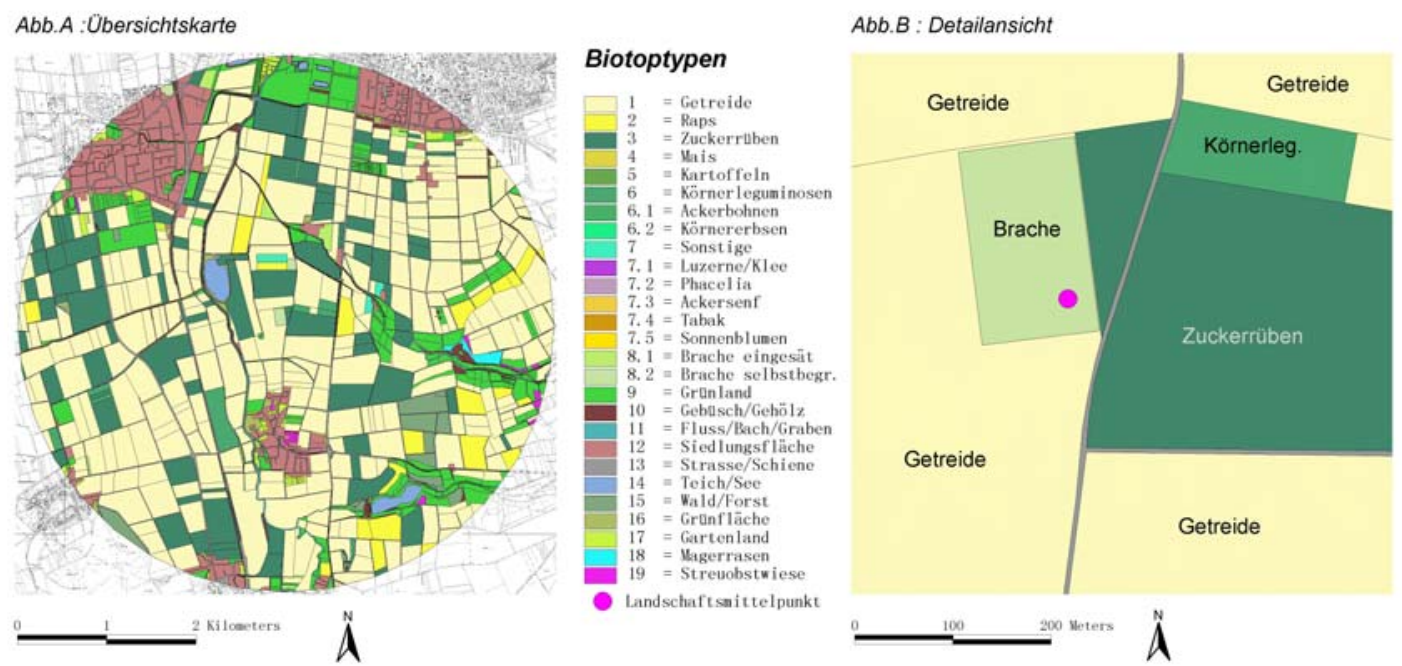

Abb. 2: Karte zur Biotopkartierung, durchgeführt im Jahr 2001 und 2002 in 18 unterschiedlich strukturierten Landschaften im Untersuchungsgebiet Landkreis Göttingen, beispielhaft für die Untersuchungslandschaft 01 „Reinshof“ (2001) 


\section{BESTÄUBERGRUPPEN UND FRUCHTANSATZ}

\section{Bestäubergruppen}

Neben den solitären Wildbienen und Hummeln sind die Honigbienen die wichtigsten Bestäuber von Kultur- und Wildpflanzen. Um diese möglichst flächendeckend erfassen zu können, wurde im Landkreis Göttingen ein Imkereikataster erstellt. Aufgrund dieser Datenlage konnte die potentielle Bestäubung für den Landkreis Göttingen abgeschätzt werden (Kapitel 2).

Für Wildbienen ist nicht nur das Blütenangebot und die Verfügbarkeit von Nahrungsressourcen wichtig, sondern auch das Vorhandensein von geeigneten Nistplätzen (Westrich 1989, Gathmann 1998). Um die Artendiversität auf den Untersuchungsflächen ermitteln zu können, wurden Nisthilfen für Wildbienen (Gathmann 1998, Tscharntke et al. 1998) im Zentrum der 18 Landschaftsausschnitte aufgestellt. Neben der Erfassung des Artenspektrums, der Schlupfrate und des Geschlechterverhältnisses, können so zusätzlich Aussagen über Parasitierung und damit Angaben über natürliche Gegenspieler gemacht werden. Diese Daten wurden durch Transektbegehungen auf den Untersuchungsflächen (Raps) vervollständigt (Kapitel 3+4).

\section{Blütenbesucher und Fruchtansatz}

Ergebnisse älterer Studien deuten darauf hin, dass eine erhöhte Abundanz an blütenbesuchenden Bienen zu einer Ertragssteigerung bzw. zu einem erhöhten Fruchtansatz bei Raps führen kann (Langridge (1975). In der vorliegenden Arbeit wurden Feldversuche mit Winterraps (Brassica napus L.) durchgeführt, um die Effektivität der Bestäubung in den unterschiedlich strukturierten Landschaften $\mathrm{zu}$ quantifizieren, (1) unabhängig von der Bewirtschaftungsweise, Bodenqualität und Rapssorte und (2) unter realen Bewirtschaftungsbedingungen (Kapitel 5+6).

\section{ERGEBNISSE}

Bei der Verteilung der bestehenden Honigbienenstände ist die vornehmlich geklumpte Lage in Siedlungsnähe auffällig, da nur wenige Imker ihre Bienen direkt in der Agrarlandschaft halten. Daraus resultiert schon jetzt eine Unterversorgung mit Honigbienen in manchen Regionen das Landkreises Göttingen. Mitgliederschwund und eine Überalterung der 
Imkervereine werden bei den derzeitigen Verhältnissen zu einer weiteren Abnahme an Bienenständen führen. Die Folge wäre ein drastischer Rückgang an Honigbienenvölkern innerhalb der nächsten 20 Jahre. Die beiden entwickelten Szenarien zeigten deutlich eine Verringerung der potentiell bestäubten Agrarfläche auf ca. $60 \%$. Somit wären $40 \%$ der Agrarfläche Göttingens mit Honigbienen unterversorgt (Kapitel 2).

Die Landschaftsstruktur der Umgebung hatte einen signifikanten Einfluss auf die Abundanz und Artenzahl von blütenbesuchenden Wildbienen. Diese stiegen mit zunehmender Landschaftsdiversität bzw. mit einem erhöhten Anteil an naturnahen Habitaten um die untersuchten Habitate an. Hier war die Habitatzusammensetzung wichtig, entsprechend den Aktionsradien der unterschiedlichen Bestäubergilden. Solitäre Wildbienen wurden stärker von der näheren Umgebung beeinflusst als die sozialen Honigbienen, die Landschaftsmuster auf größeren räumlichen Skalen wahrnahmen.

Die Landschaftsstruktur spielte hierbei nur eine untergeordnete Rolle. Kleinstrukturierung und Fragmentierung von Landschaften schienen keinen großen Einfluss auf die Zusammensetzung von Wildbienenlebensgemeinschaften zu haben. Dabei sprachen die drei Bestäubergilden (solitäre Wildbienen, Hummeln und Honigbienen) unterschiedlich auf räumliche Skalen an. Solitäre Wildbienen traten sehr lokal auf (Skala bis 500m), Hummeln und Honigbienen konnten auf größeren Skalen verfolgt werden (Hummeln bis 1000m; Honigbienen $>3000 \mathrm{~m}$ ). In dieser Arbeit konnte nachgewiesen werden, dass wertvolle Habitate wie Brache, Grünland, Hecke, Streuobstwiese und Magerrasen und deren erhöhter Anteil an der Gesamtlandschaft sich positiv auf blütenbesuchende Wildbienen auswirken. Die Abundanz von blütenbesuchenden Bienen auf Winterraps (Brassica napus L.) in unterschiedlich strukturierten Landschaften war von dem Anteil naturnaher Habitate abhängig. Wildbienen und Honigbienen sprachen beide auf einen erhöhten Anteil naturnaher Habitate beim Blütenbesuch bei Raps an. Jedoch hatte diese erhöhte Abundanz keinen messbaren Effekt auf den Fruchtansatz bei Raps. Lediglich eine erhöhte Abundanz an Honigbienen resultierte in einen erhöhten Fruchtansatz, was aber zu keiner signifikanten Ertragssteigerung $\left(\mathrm{g} / \mathrm{m}^{2}\right)$ führte.

Bei den Untersuchungen an Winterraps (Brassica napus L.) zeigte sich, dass die umgebende Landschaft mit ihrer Landschafsstruktur keinen direkt messbaren Einfluss auf den Fruchtansatz hat. Lediglich der Anteil an Rapsfeldern in näherer Umgebung führte zu einem erhöhten Ertrag. Vor allem die Windbestäubung scheint für den Fruchtansatz bei Raps ausschlaggebend zu sein. Dennoch konnte nachgewiesen werden, dass eine erhöhte Abundanz an Honigbienen eine effizientere Bestäubung bedingen und somit eine Kombination aus 
Windbestäubung und Insektenbestäubung zu einem erhöhten Fruchtansatz führen sollten (Kapitel 5+6).

\section{SCHLUSSFOLGERUNGEN}

Viele Kultur- und Wildpflanzen sind auf Bestäubung zur Frucht- und Samenproduktion angewiesen. Die gegenwärtige Sicherheit der Bestäubung durch Honigbienen stellt sich im Landkreis Göttingen als kritisch dar. Viele Imkervereine sind durch Überalterung ihrer Mitglieder bei gleichzeitig rückläufigen Mitgliederzahlen gekennzeichnet. Das in dieser Arbeit aufgezeigte Beispiel des Landkreises Göttingen belegt, dass ein weiterer Rückgang an Bestäubern, vor allem der Honigbiene vermieden werden sollte. Bei der Verteilung der bestehenden Bienenstände war die vornehmlich geklumpte Lage in Siedlungsnähe auffällig, da nur wenige Imker ihre Bienen direkt in der Agrarlandschaft hielten. Zeitmangel und eine schnellere Erreichbarkeit der Bienenstände und bessere Trachtverhältnisse in Ortsnähe sind mögliche Ursachen. In vielen Landschaftsabschnitten sind keine oder nur noch wenige Honigbienen vorhanden, so dass solche unterversorgten Landschaften von einem weiteren Rückgang massiv betroffen wären und eine Bestäubung der Wild- und Kulturpflanzen dann vermehrt durch Wildbienen gewährleistet werden müsste. Die Honigbiene nutzt eine Vielzahl an Blühpflanzen als Trachtquelle. Sie kann nicht durch Wildbienen ersetzt werden, da auch diese durch die Intensivierung der Landwirtschaft dezimiert werden. Ob die Haltung der Honigbienen auch in Zukunft noch flächendeckend gewährleistet ist, scheint unter den derzeitigen Bedingungen fraglich, da die Intensivierung der Landwirtschaft, veränderte Trachtsituationen und die derzeit verstärkt auftretenden Krankheiten zu einem weiteren Rückgang führen werden.

Neben den Honigbienen sind solitäre Wildbienen eine weitere wichtige Bestäubergilde. Die Untersuchungen dieser Arbeit zeigten eine Abhängigkeit von blütenbesuchenden Wildbienen und Honigbienen von der umgebenden Landschaft auf unterschiedlichen räumlichen Skalen. So hat die Zerstörung naturnaher Habitate auf kleinen räumlichen Skalen einen weitaus größeren Einfluss auf die lokale solitäre Wildbienenfauna als auf die Abundanz sozialer Bienen. Folglich hängt eine lokale Wildbienenlebens-gemeinschaft unmittelbar von der umgebenden Landschaft ab.

Diese lokalen landschaftsbeeinflussten Effekte konnten nicht im Zusammenhang mit dem Fruchtansatz an Winterraps (Brassica napus L.) gefunden werden. Raps, als Selbstbestäuber, 
profitiert von einer effektiven Windbestäubung, die vermutlich durch einen erhöhten Anteil an Rapsflächen in näherer Umgebung noch gesteigert werden kann. Dennoch konnte durch blütenbesuchende Insekten ein positiver Trend hin zu einem höheren Fruchtansatz festgestellt werden. Demnach wäre es auch aus ökonomischer Sicht relevant, eine optimierte Bestäubung durch Wind- und Insektenbestäubung zu erzielen. Positive Folgen wären hierbei eine kürzere Blühperiode, ein gleichmäßigeres Abreifen der Früchte und somit weniger Ernteverluste.

In dieser Arbeit konnte somit die Bedeutung von Habitatkomposition und Landschaftsstruktur auf kleinen räumlichen Skalen auf lokale Bienendiversitäten und -abundanzen nachgewiesen werden. Generell unterliegen Agrarlandschaften starken Störungen durch intensive Landwirtschaft, wodurch die lokalen Wildbienen zunehmend gefährdet sind. Ein Landschaftsmanagement zum Schutz dieser für die Bestäubung von Kultur- und Wildpflanzen so wichtigen Insektengruppe könnte zum Erhalt wichtiger ökologischer Funktionen beitragen.

\section{LITERATUR}

Allen-Wardell, G.,Bernhardt, P., Bitner, R., Burquez, A., Buchmann, S., Cane, J., Cox, P.A., Dalton, V., Feinsinger, P., Ingram, M., Inouye, D., Jones, C.E., Kennedy, K., Kevan, P., Koopowitz, H., Medellin, R., Medellin-Morales, S., Nabhan, G.P., Pavlik, B., Tepedino, V., Torchio, P., Walker, S. (1998): The potential consequences of pollinator declines on the conservation of biodiversity and stability of food crop fields. Conservation Biology 12: 1-11.

Antrop, M. (2000): Background concepts for integrated landscape analysis. Agriculture, Ecosystems and Environment 77: 17-28.

Bienefeld, K. (1996): Die Bedeutung der Bienenhaltung in Deutschland. Deutsches Bienenjournal 5:14-18.

Bierregard R., Lovejoy, T., Kapos, V., Dos Santos, A. \& R. Hutchings (1992): The biological dynamics of tropical rainforest fragments. Bio-Science 42: 859-866.

Blaschke T. (1999): Quantifizierung von Fragmentierung, Konnektivität und Biotopverbund mit GIS. Veröffentlicht in: J.STROBL und T. BLASCHKE: Angewandte Geographische Informationsverarbeitung. Beiträge zum AGIT-Symposium Salzburg 1999. 
Blaschke, T. and Petch, J. (1999): Landscape structure and scale: comparative studies on some landscape indices in Germany and the UK. In: Maudsley, M. and Marshall, J. (eds.), Heterogeneity in landscape ecology: pattern and scale. IALE UK, Bristol, 7584.

Borman, F.H., Likens, G.E. (1979): Pattern and process in a forested ecosystem. New York: Springer Verlag.

Bürger, C. (2000): GIS-gestützte Landschaftsstrukturanalyse und die Verbreitungsmuster von Wildbienen-Lebensgemeinschaften. Diplomarbeit, angefertigt am Geographischen Institut der Universität Göttingen (unveröffentlicht).

Conradi, M. (2000): Schritte auf dem Weg zu einer ökologischen differenzierten, artzentrierten GIS-Analyse. Veröffentlicht in: J.STROBL / T.BLASCHKE / G. GRIESEBNER: Angewandte Geographische Informationsverarbeitung XII. Beiträge zum AGIT-Symposium Salzburg 2000: 72-81.

Davis, J., Howe, R., Davis, G. (2000): A multi-scale spatial analysis for point data. Landscape Ecology 15: 99-144.

Drachenfels, O. (1994): Kartierschlüssel für Biotoptypen in Niedersachsen, Stand September 1994. Niedersächsiches Landesamt für Ökologie, Hannover.

Gasper, P. \& Menz, G. (1999): Landschaftsmaße zur Bestimmung der räumlichen Strukturen in klassifizierten Satellitenbildern. Publ. Der Dt. Gesellschaft für Photogrammetrie 7: 333-340.

Gathmann, A. (1998): Bienen, Wespen und ihre Gegenspieler in der Agrarlandschaft: Artenreichtum und Interaktionen in Nisthilfen, Aktionsradien und Habitatbewertung. Dissertation an den Mathematisch-Naturwissenschaftlichen Fakultäten der GeorgAugust-Universität zu Göttingen. Cuvillier Verlag Göttingen.

Gustafson, E.J. (1998): Quantifying landscape spatial pattern: What is the state of the art? Ecosystems 1:143-156.

Hanski, I. (1999): Habitat connectivity, habitat continuity and metapopulations in dynamic landscapes. Oikos 87: 209-219.

Hanski, I. (1997): Habitat destruction and metapopulation dynamics. In: Pickett, S. et al. (eds.), The ecological basis of conservation. Heterogeneity, ecosystems, and biodiversity. Chapman \& Hall, New York u.a., 217-227. 
Hulshoff, R. (1995): Landscape indices describing a Dutch landscape. Landscape Ecology 10: 101-111.

Huston, M.A. (1979): A general hypothesis of species diversity. American Naturalist 113: 81101.

Kaveira, P. , Wennergren, U. (1995): Connecting landscape patterns to ecosystem and population processes, Nature 373: 299-302.

Kearns, C.A., Inouye, D.W. \& Waser, N.M. (1998): Endangered mutualisms: the conversation of plant-pollinator interactions. Annual Review of Ecology and Systematics 2: 83-112.

Kleyer, M., Kaule, G., Settele, J. (1996): Landscape fragmentation and landscape planning, with a focus of Germany. Kluwer academic Publishers: 138-151.

Kremen, C., Williams, N.M., Thorp, R.W.(2002): Crop pollination from native bees at risk from agricultural intensification. Proceedings of the National Academy of Science of the United States of America 99 (26): 16812-16816.

Kruess, A. and Tscharntke, T. (1994): Habitat fragmentation, species loss, and biological control. Science 264: 1581-1584.

Langridge, D. F. \& R. D. Goodman (1975): A study on pollination of oilseed rape (Brassica campestris). Australian Journal of Experimental Agriculture and Animal Husbandry 15(73): 285-288.

Li, B.-L. and Archer S. (1997): Weighted mean patch size: a robust index for quantifying landscape structure. Ecological modeling 102: 353-361.

PATCH-Analyst (2000): Utility for spatial analysis and attribute modelling of landscape patches. Version 2.2. Sustainable Forest Management Network (NCE) and Centre for Northern Forest Ecosystem Research (OMNR).

Rathcke, B. J., and E. S. Jules. (1993): Habitat fragmentation and plant-pollinator interactions. Current Science 65: 273-77.

Riitters, K., O’Neill, R.V., Hunsacker, C.T:, Wickham, J.D., Yankee, D.H:, Timmins, S.P., Jones, K.B. \& Jackson, B.L. (1995): A factor analysis of landscape pattern and structure metrics. Landscape Ecology 10: 23-39.

Schlatter, C. \& Duelli, P. (2000): Mit Landschaftsstrukturen Biodiversität schätzen? Mitt. Dtsch. Ges. Allg. Angew. Ent. 12: 375-378. 
Steffan-Dewenter, I., Münzenberg, U., Tscharntke, T. (2001): Pollination, seed-set und seed predation on a landscape scale. Proceedings of the Royal Society London, Series B 268: 1685-1690.

Steffan-Dewenter, I. \& Tscharntke, T. (1997): Bee diversity and seed set in fragmented habitats. Acta Horticulturae 437: 231-234.

Thies, C. \& Tscharntke, T. (1999): Landscape structure and biological control in agroecosystems. Science 285: 893-895.

Tscharntke, T. , Gathmann A. and Steffan-Dewenter, I. (1998): Bioindication using trapnesting bees and wasps and their natural enemies: community structure and interactions. Journal of Applied Ecology 35: 708-719.

Walz, U. (1998): Ableitung von Indikatoren zur Landschaftsstruktur aus Fernerkundungsdaten und anderen Flächeninformationssystemen. Veröffentlicht in: J.Strobl \& F.Dollinger (1998): Angewandte Geographische Informationsverarbeitung. Beiträge zum AGIT-Symposium Salzburg 1998. Heidelberg

Westrich, P. (1989): Die Wildbienen Baden-Württenbergs (2 Bde.), Ulmer Stuttgart.

Wiens, J.A. (1989): Spatial scaling in ecology. Funct. Ecol. 3: 385-397 


\section{Ist die Bestäubung in Zukunft noch gesichert?}

\section{Wissenschaftler errechnen, wie sich die Bestäubungssituation bei rückläufigen Imkerzahlen entwickeln könnte}

Schon jetzt herrscht in vielen Regionen Deutschlands ein Mangel an Bienen. Größere Teile der Agrarlandschaft werden nicht ausreichend von Bestäubern besucht. Wie entwickelt sich diese Situation, wenn die Zahl der Imker und Bienenvölker - dem aktuellen Trend folgend weiter rückläufig bleibt? Wissenschaftler der Universität Göttingen entwickelten ein Zukunftsszenario, in dem sie am Beispiel des Landkreises Göttingen ermittelten, wie die Situation dort in etwa 20 Jahren aussehen könnte.

Die Vielfalt in der Pflanzen- und Tierwelt ist eine wichtige Voraussetzung zur Erhaltung eines funktionsfähigen Naturhaushaltes. Das gilt auch für die Bestäubung und den damit verbundenen Frucht- und Samensatz der Wild- und Kulturpflanzen. Hierfür ist eine ausreichende Vielfalt und Dichte von Bestäubern nötig. Dazu tragen Artenvielfalt und Individuenzahlen der wildlebenden Bienen ebenso bei wie die gleichmäßige Verteilung imkerlich genutzter Honigbienenvölker. Ohne Bestäubung ist die Arterhaltung vieler Pflanzen und damit auch das Überleben vieler Tier- und Insektenarten gefährdet.

\section{WILD- UND HONIGBIENEN WERDEN WENIGER}

Die Zerstörung naturnaher Lebensräume hat in den letzten Jahrzehnten zu einem gravierenden Rückgang der Wildbienen geführt. Gleichzeitig nahm in dieser Zeit auch die Zahl der von Imkern gehaltenen Bienenvölker ab. Hierfür können mehrere Gründe angebracht werden. Als Hauptursache ist der Mitgliederrückgang in den Imkervereinen selbst zu nennen, hervorgerufen durch Überalterung und fehlenden Nachwuchs. Mit den Imkern verschwinden auch die Bienen. 1988 bewirtschafteten in Niedersachsen 8.500 Imker mehr als 91.000 Bienenvölker, im Jahr 2000 waren es immer noch 8.500 Imker, die aber nur noch 75.000 Bienenvölker betreuten (Informationen des Landesverbandes Hannoverscher Imker e.V.). Dies bedeutet eine Abnahme an Völkern von ca. 20\% in nur zwölf Jahren (Weitere Angaben zu Mitgliederzahlen der alten Bundesländer s. Tab.1). Ein weiteres großes Problem ist die Zunahme von Bienenkrankheiten und Parasiten. Hierbei hat vor allem die Varroamilbe eine hohe Bedeutung. Extreme Ausfälle, vermutlich bedingt durch die Varroa, führten im Winter 2002/2003 zu einem bundesweitem Völkerverlust von über 30\%, in manchen Regionen sogar über $50 \%$. 
Tabelle.1: Mitgliederzahlen des Deutschen Imkerbundes (D.I.B.) und Zahl der gehaltenen Bienenvölker in den alten Bundesländern 1989 und 2000

\begin{tabular}{lccccc}
\hline \hline Landesverband & \multicolumn{2}{c}{ Anzahl Imker } & & \multicolumn{2}{c}{ Anzahl Bienenvölker } \\
& Stand 1989 & Stand 2000 & & Stand 1989 & Stand 2000 \\
\cline { 1 - 3 } \cline { 5 - 6 } Baden & 7.811 & 7.564 & & 108.157 & 81.831 \\
Bayern & 27.941 & 25.046 & & 403.118 & 287.585 \\
Berlin & 543 & 518 & & 3.300 & 2.754 \\
Hamburg & 465 & 329 & & 3.619 & 1.916 \\
Hannover & 6.527 & 5.622 & & 63.622 & 47.529 \\
Hessen & 8.070 & 7.220 & & 80.659 & 57.299 \\
Nassau & 586 & 486 & & 5.443 & 3.830 \\
Rheinland & 6.520 & 5.629 & & 52.276 & 42.295 \\
Rheinland-Pfalz & 1.791 & 1.863 & & 17.875 & 13.139 \\
Saarland & 1.553 & 1.400 & & 19.124 & 9.335 \\
Schleswig-Holstein & 3.439 & 2.920 & & 36.042 & 25.589 \\
Weser-Ems & 2.463 & 2.688 & & 23.786 & 22.497 \\
Westfalen-Lippe & 6.617 & 6.007 & & 52.345 & 41.946 \\
Württemberg & 10.421 & 9.127 & & 127.271 & 95.689 \\
\multicolumn{1}{c}{ Gesamt } & 84.747 & 76.419 & & 996.637 & 733.234
\end{tabular}

Anmerkung: Die Zahl der D.I.B.-Imker ging in dieser Zeit im Bundesdurchschnitt um 10\%, die Anzahl der Bienenvölker um 26\% zurück.

\section{IMKEREIKATASTER IM JAHR 2002 ERSTELLT}

Die Trachtsituation hat sich verändert: Massentrachten im Frühjahr, wenige Trachtquellen im Sommer und Spätsommer. Flurbereinigung, Zerstörung naturnaher Habitate und Insektizideinsatz sind Begeleiterscheinungen einer Intensivierung der Landwirtschaft. All diese Faktoren führen dazu, dass die Zahl der Bestäuber rückläufig ist. So kommt zwangsläufig die Frage auf, ob eine flächendeckende Bestäubung bei gleichbleibendem Negativtrend überhaupt noch gewährleistet ist.

Um dieser Frage nachzugehen, wurde erstmalig für das Land Niedersachsen im Landkreis Göttingen unter Mitarbeit des Bieneninstituts Celle und den ortsansässigen Imkereivereinen ein Imkereikataster initiiert, dass der Erfassung der Honigbienenstandorte dienen sollte. Hierzu wurden im Jahr 2002 die Bienenstandorte aller Imker durch Befragung der Vereinsvorsitzenden ermittelt, in dieses Imkereikataster aufgenommen und durch weitere Standortdaten erweitert, so dass nach Schätzung ca. 90\% aller Bienenstandorte erfasst werden konnten. Freie Imker, die nicht in Vereinen organisiert sind, konnten demnach nur unvollständig in das Kataster integriert werden. Insgesamt wurden somit 255 Bienenstandorte im Jahr 2002 für den Landkreis Göttingen erfasst, deren Lagen vornehmlich durch Orts- bzw. 
Siedlungsnähe gekennzeichnet waren. Die Befragung umfasste zusätzlich noch Daten zur Haltung, Zucht, Krankheitsauftreten und Honigertrag der Bienenstände.

Zur Abschätzung, inwieweit sich die Bestäubersituation in den nächsten zwei Jahrzehnten entwickeln könnte, wurde ein Fallbeispiel für den Landkreis Göttingen auf Basis der erfassten Standorte entwickelt.

\section{ZUKUNFTSSZENARIEN FÜR 2022 - BESTÄUBUNGSLÜCKE WÄCHST}

Dem wurden zwei Szenarien mit unterschiedlich starkem Mitgliederschwund bzw. Verlust an Bienenstandorten zu Grunde gelegt. Hintergrund für die Szenarien ist der Sammelradius der Honigbiene, der nach Ergebnissen unserer Arbeitsgruppe normalerweise eine Distanz von ein bis zwei Kilometern umfasst. So wurde in beiden Szenarien ein Sammelradius von 1,5 Kilometern um jeden Bienenstandort gelegt, so dass Flächen ausgewiesen werden konnten, die potenziell von den Honigbienen bestäubt werden. Die gesamte Agrarfläche des Landkreises Göttingen beträgt $627 \mathrm{~km}^{2}$. Im Jahr 2002 waren in unserem Modell $70 \%$ der Agrarfläche durch Honigbienen der 255 Bienenstandorte abgedeckt. Folglich sind schon jetzt $30 \%$ der Agrarfläche des Landkreises Göttingen mit Honigbienen als Bestäuber unterversorgt! (Abb. 1a)

Dem ersten Szenario wurde entsprechend dem bundesweiten Trend im Mitgliederschwund von jährlich 1,4\% zugrunde gelegt. Demzufolge würden die Mitgliederzahlen für die Imkereivereine des Landkreises Göttingen von 231 im Jahr 2002 auf 174 Mitglieder im Jahr 2022 sinken (Verlust ca. 25\%). Bei einem ähnlichen Schwund an Bienenständen würden hierbei im selben Zeitraum 63 Bienenstände verloren gehen. Parallel würde auch die potenziell bestäubte Agrarfläche abnehmen. In diesem Fall würde die bestäubte Fläche von $436 \mathrm{~km}^{2}$ (2002) auf $387 \mathrm{~km}^{2}$ sinken. Somit wäre in diesem Szenario die Bestäubung durch Honigbienen im Jahr 2022 auf ca. 38\% der Agrarfläche des Landkreises Göttingen nicht gesichert (Abb. 1b).

Im zweiten Szenario wurde ein jährlicher Mitgliederschwund bzw. Verlust an Bienenständen von $2 \%$ angenommen. Vermehrt auftretende Bienenkrankheiten und Völkerverluste, wie sie beispielsweise im Frühjahr 2003 aufgetreten sind, stützen die Annahme eines erhöhten Verlustes an Honigbienen. Die angenommene Entwicklung wäre gleichbedeutend mit einem Mitgliederschwund von 231 auf 154 Mitglieder (Verlust: 77 Mitglieder) und würde dadurch 
erheblich höher als der im Szenario I angenommene Rückgang liegen. Gleichbedeutend würde die Zahl der Bienenstände von 255 auf 170 sinken (Verlust 85 Standorte). Der Rückgang potenziell bestäubter Agrarfläche läge somit deutlich über dem im Szenario I dargestellten Flächenverlust. So würden hierbei nur noch ca. 44\% der gesamten Agrarfläche des Landkreises Göttingen durch Honigbienen beflogen (Abb. 1c).

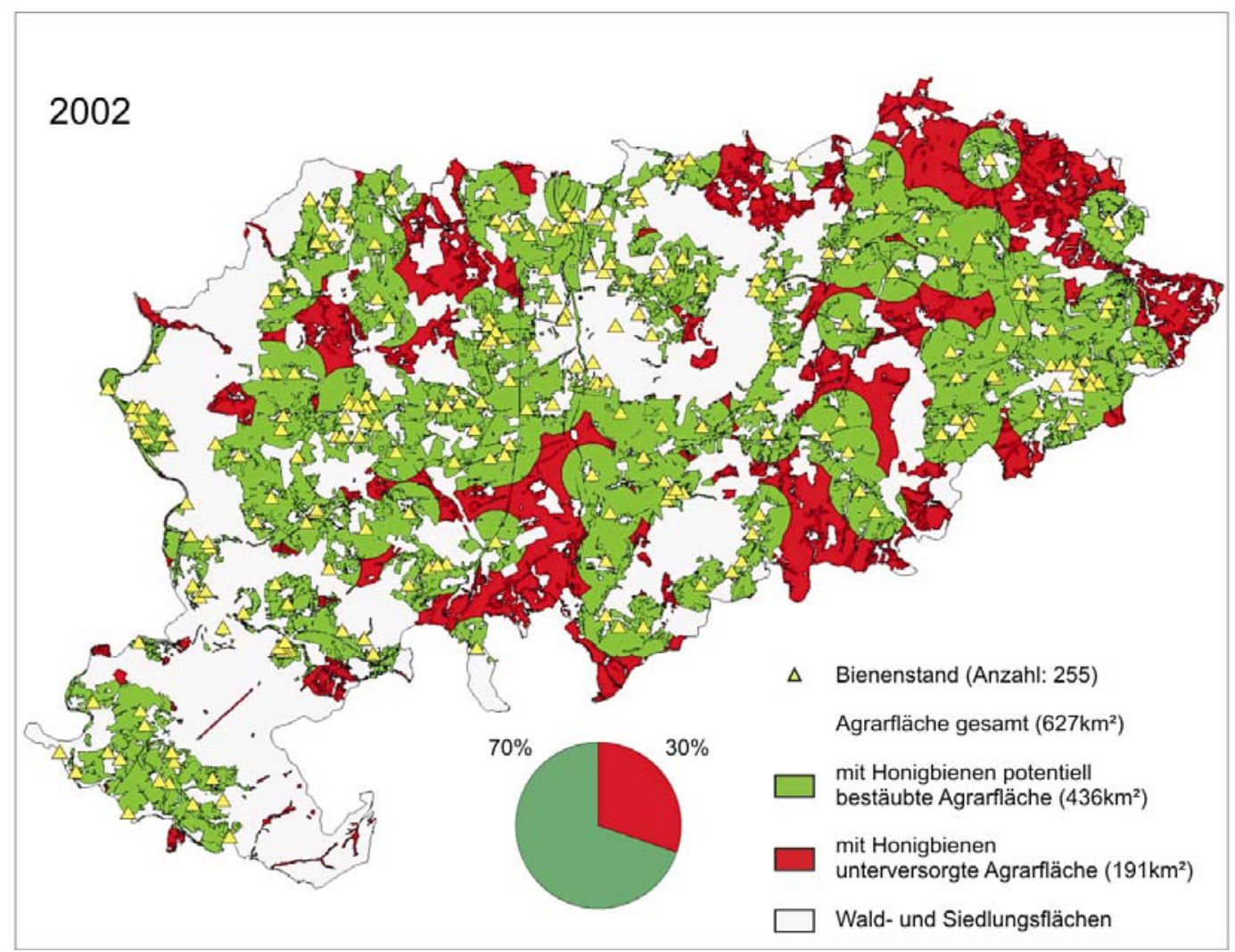

Abb. 1a: Honigbienenstände und potentiell bestäubte Agrarfläche im Landkreis Göttingen, Stand 2002 


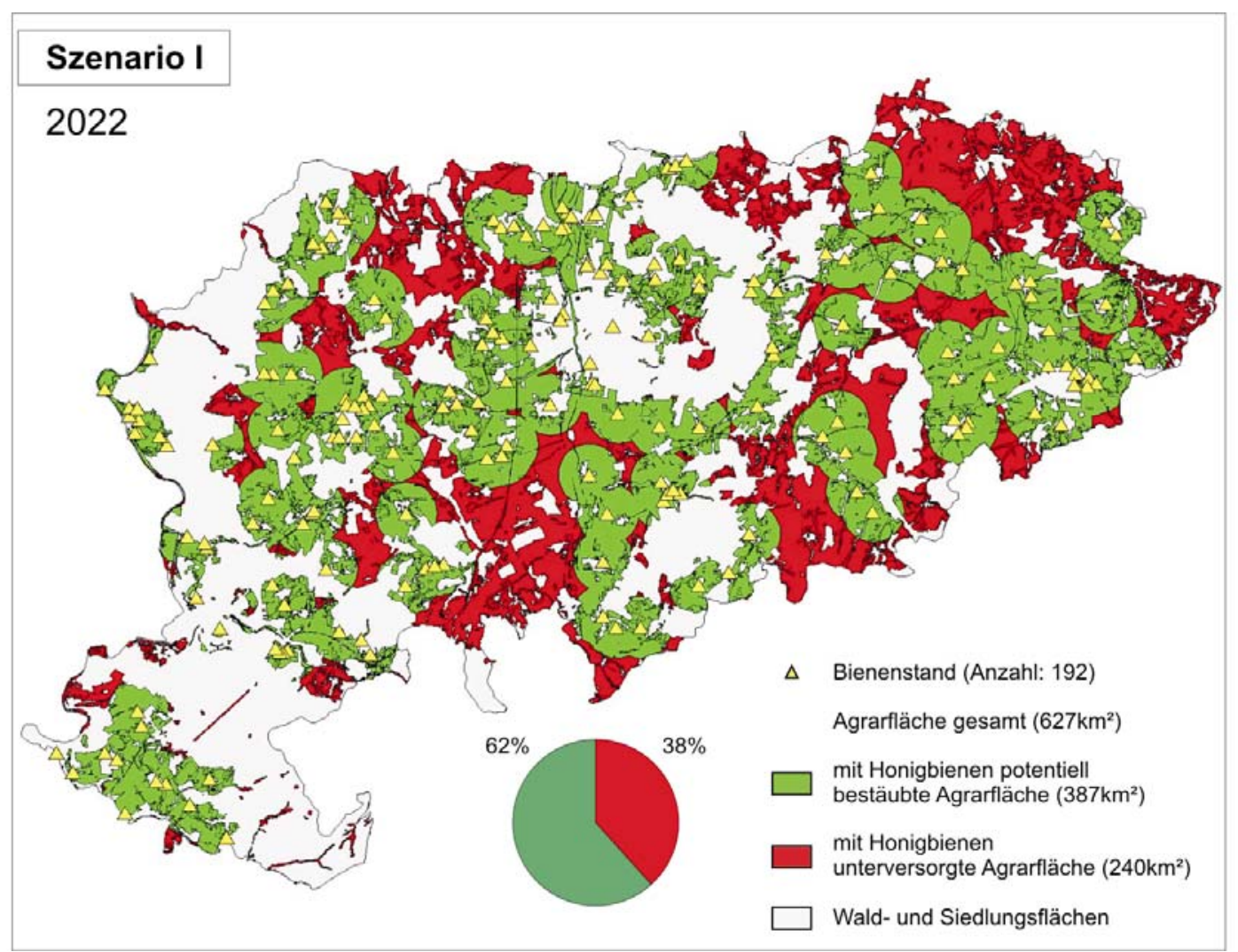

Abb. 1b: Honigbienenstände und potentiell bestäubte Agrarfläche im Landkreis Göttingen unter Berücksichtigung eines Ständeverlustes von jährlich 1,4\% in einem Zeitraum von 20 Jahren (Szenario 1)

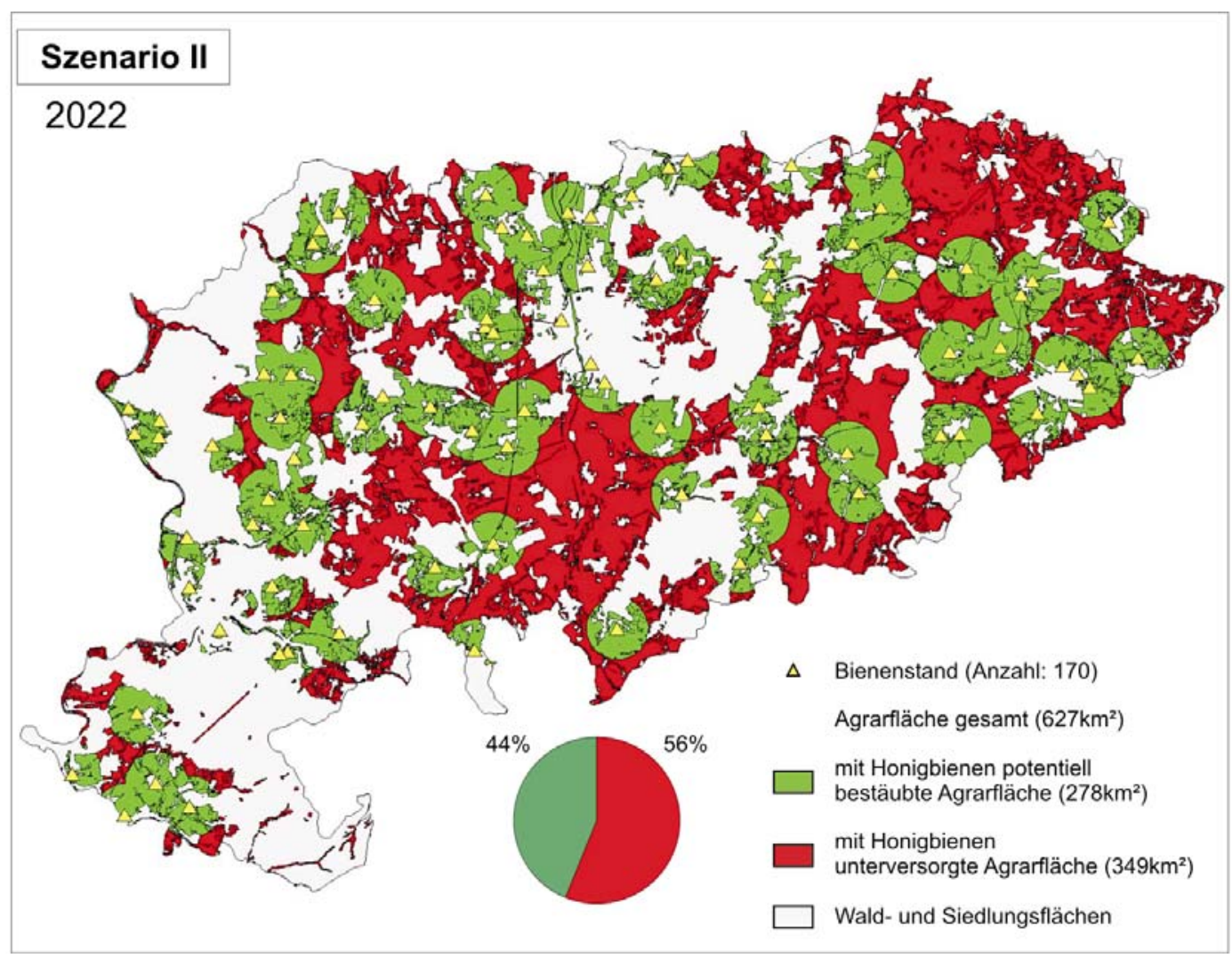

Abb. 1c: Honigbienenstände und potentiell bestäubte Agrarfläche im Landkreis Göttingen unter Berücksichtigung eines Ständeverlustes von jährlich $2 \%$ in einem Zeitraum von 20 Jahren (Szenario 2) 


\section{BIENENSTÄNDE SIND NICHT GLEICHMÄSSIG VERTEILT}

Die gegenwärtige Bestäubungssituation durch Honigbienen stellt sich als kritisch dar. Viele Imkervereine sind durch Überalterung ihrer Mitglieder bei gleichzeitig rückläufigen Mitgliederzahlen gekennzeichnet, da nur wenige neue und jüngere Mitglieder für das Hobby „Imkerei“ gewonnen werden können. Das hier aufgezeigte Beispiel des Landkreises Göttingen belegt, dass ein weiterer Rückgang an Bestäubern vermieden werden sollte.

Bei der Verteilung der bestehenden Bienenstände ist die vornehmlich geklumpte Lage in Siedlungsnähe auffällig. Dadurch ergibt sich auch der erheblich höhere Flächenverlust im zweiten Szenario bei einem Wegfall von Honigbienen ganzer Ortschaften (nicht linearer Zusammenhang). Nur wenige Imker halten ihre Bienen direkt in der Agrarlandschaft. Zeitmangel und eine schnellere Erreichbarkeit der Bienenstände scheinen die Ursache hierfür zu sein. Dies wurde auch bei der Auswertung der Fragebögen deutlich, denn nur wenige der teilnehmenden Imker wanderten Trachtquellen direkt an.

Daher sind in vielen Teilen des Landkreises keine oder nur noch wenige Honigbienen vorhanden, so dass solche unterversorgten Landschaften von einem weiteren Rückgang massiv betroffen wären und eine Bestäubung der Wild- und Kulturpflanzen dann vermehrt durch Wildbienen gewährleistet werden müsste. Viele Kultur- und Wildpflanzen sind auf Bestäubung zur Frucht- und Samenproduktion angewiesen. Die Honigbiene aber, die ca. 80\% aller Blühpflanzen als Trachtquelle nutzt, kann nicht durch Wildbienen ersetzt werden, da auch diese durch die Intensivierung der Landwirtschaft dezimiert werden.

\section{IMKERSCHAFT STÄRKEN, WILDBIENEN FÖRDERN}

$\mathrm{Ob}$ die Haltung der Honigbienen auch in Zukunft noch flächendeckend gewährleistet ist, scheint unter den derzeitigen Bedingungen fraglich. Zur Klärung dieser komplexen Frage soll das Imkereikataster für den Landkreis Göttingen fortgeführt werden, um die zeitliche wie räumliche Dynamik in der Verteilung der Bienenstände erfassen zu können.

Dennoch muss an dieser Stelle ein Umdenken stattfinden, einerseits zur Stärkung der Imkerschaft und andererseits zur Förderung der heimischen Wildbienenfauna durch ökologisch angepasste Landnutzung. 


\section{Species richness of trap-nesting bees and wasps on fallows and oilseed rape fields in a gradient of landscapes complexity}

\section{ABSTRACT}

Human activities in ecosystems often reduce species diversity, alter species composition and increase the risk of species extinction. In this study we analysed the effects of landscape context and the influence of the percentage of semi-natural habitats at twelve spatial scales (radius of the surrounding landscape: 250 - 3000m) on species composition of wild bee communities in 18 landscapes sectors representing a gradient of structurally poor to structurally rich landscapes. Each landscape sector contained a fallow and a rapecrop field as study sites. Wild bee communities were recorded using traps made of reed. Altogether, 3237 reed nests containing 13726 brood cells of eight solitary bee species (Hymenoptera: Apidae), four sphecid wasp species (Hymenoptera: Sphecidae), six eumenid wasp species (Hymenoptera: Eumeninae) and one spider wasp species (Hymenoptera: Pompilidae) were found in the 18 landscapes. We suspected, (1) the local abundance and diversity of bees differ between fallow and rapecrop field and (2) an increasing proportion of the semi-natural habitats in the surrounding landscape has a positive effect on species diversity. In contrast to our expectations, we found no differences in bee diversity and bee abundance between the two different study sites. Furthermore, an increasing percentage of semi-natural habitats had no measurable effect on species composition at any spatial scale. However, an increasing proportion of rapecrop fields (within a radius of 500-750m) reduced the number of brood cells per nest, but enhanced number of nests of the solitary wild bee Osmia rufa (Hymenoptera: Apidae). In conclusion, mass resources provided in oilseed rape fields may enhance populations of social bees but not solitary bees. There is a need for experimental studies that take into account the real complexity of the surrounding landscape in intensively used agricultural landscape to explain the structure of wild bee communities.

\section{Key words}

Bees; wasps; community structure; species diversity; landscape ecology; spatial scales;. 


\section{INTRODUCTION}

Within the last decades human activity has resulted in increasing destruction and fragmentation of natural habitats. Human interventions in ecosystems often reduce species diversity, alter species composition and increase the risk of species extinction (Bierregard et al. 1992, Antrop 2000, Matthies et al. 2004). The effects of habitat fragmentation and change of landscape context on a variety of species and ecosystems are a current topic of ecological research (Saunders et al. 1991, Kleyer et al. 1996, Hanski 1999, Harrison \& Bruna 1999). Landscape ecology examines relationships between landscape complexity, ecological processes and species diversity (Gustafson 1998). Landscape patterns are quantified by a great variety of landscape indices or parameters using Geographical Information Systems (e.g. Walz 1999), however most of them are inter-correlated and difficult to interpret in relation to ecological functions. Ecological processes are measured by response variables (process rates), such as dispersal success, survival probability of populations or species diversity. Some studies have examined the dependence of vertebrates or plants on the characteristics of the surrounding landscape (e.g. Weibull et al. 2003), but this has been rarely examined for insects (e.g. Steffan-Dewenter 2002).

In fact, the intensification of agricultural land use and destruction of natural habitats cause not only species loss (Saunders et al. 1991, De la Pena et al. 2003) but also the disruption of important ecological functions such as pollination of plants or pest control of plants or insects by their natural antagonists (Rathcke \& Jules 1993, Allen-Wardell et al. 1998, SteffanDewenter \& Tscharntke 1999, Thies \& Tscharntke 1999, Menalled et al. 1999, Cunningham 2000).

Previous research results show that structurally rich landscapes contain a higher abundance and diversity of wild bees (Steffan-Dewenter et al. 2002). These structurally rich landscapes are characterised by a high habitat diversity offering sufficient food resources and nesting sites for bees (Gathmann \& Tscharntke 1999). Due to the intensification of agriculture, many important habitats have been destroyed and therefore endanger many specialised species of wild bees.

Wild bees visiting numerous wild and crop plant species (Free 1993, Steffan-Dewenter et al. 2001, 2002). Trap-nesting bees and wasps can be used as a sensitive indicators of habitat quality or environmental change (Tscharntke et al. 1998). With regard to solitary wild bees, traps can be used to estimate their potential pollination benefit. In this study we examined 
communities of trap-nesting bees and wasps in 18 independent landscapes to measure the effect of (1) local habitat type and (2) the surrounding landscape composition on species richness and species composition.

In the first step, we analysed the two different habitat types (a) fallows as perennial habitats with natural vegetation and (b) intensively used oilseed rape fields as annual habitats and their effects on species composition of trap-nesting bees and wasps. We hypothesised, that this local factor of habitat type has an effect of species richness and abundance. We assumed a higher species richness and abundance on fallows (Steffan-Dewenter \& Tscharntke 2001).

In the second step, we focused on regional factors using different spatial scales $(250-3000 \mathrm{~m})$ to identify the spatial scale on which bees and wasps interact with the surrounding landscape (Keitt et al. 1997). Previous studies have shown that the percentage of semi-natural habitats could have a positive effect on the species composition and abundance of wild bee communities (Steffan-Dewenter et al. 2001). Quantifying landscapes, we focused on two different landscape parameters: (1) proportion of different habitat types as a landscape composition metric (percentage of semi-natural habitats and percentage of rapecrop fields) and MPAR (Mean-Perimeter-Area-Ratio) as a measure for landscape fragmentation.

We expected that a combined effect of local (habitat type) and regional (landscape context) parameters influenced the composition of species communities of trap-nesting bees and wasps. Additionally, we expected that the availability of food resources would be an important factor for determining wild bee communities.

\section{MATERIAL AND METHODS}

\section{Study region and study sites}

The study was conducted in 2001 in the agricultural landscapes of southern Lower Saxony around the city of Göttingen (Germany) in a region spanning $45 \mathrm{~km}$ east-west and $35 \mathrm{~km}$ south-north. We selected 18 study sites that vary from structurally simple to structurally rich landscapes. The mean distance between the 18 independent study sites was $6019 \mathrm{~m} \pm 620 \mathrm{~m}$ (range from $5160 \mathrm{~m}$ to $7075 \mathrm{~m}$ ). Each landscape contained a fallow and a rape crop field as study habitats in the centre of each landscape. The distance between the study fields in each landscape was less than $200 \mathrm{~m}$. 


\section{Quantifying landscape context}

For each of the 18 landscapes, different landscape metrics were calculated in twelve circular sectors (Ø 250m, Ø 500m, Ø 750m, Ø 1000m, Ø 1250m, Ø 1500m, Ø1750m, Ø 2000m, Ø $2250 \mathrm{~m}, \varnothing 2500 \mathrm{~m}, \varnothing 2750 \mathrm{~m}, \varnothing 3000 \mathrm{~m})$ using the Geographic Information System ARC $\backslash$ View 3.2 (ESRI Geoinformatik, Hannover, Germany). These circular sectors represented a nested set of landscape sectors at twelve spatial scales. To evaluate the landuse, we used official digital maps (Deutsche Grundkarte DGK 5, Landesvermessung und Geobasisinformation, Hannover, Germany) to record the landuse of the 18 landscapes with a respective area of 28 $\mathrm{km}^{2}$. We subdivided the land use in 27 habitat types which where grouped into annual and perennial habitats types. We differed these habitat types into: (01.) grain, (02.) rapecrop fields, (03.) sugar beets, (04.) corn, (05.) potatoes, (06.) legumes ((06.1) sow beans, (06.2) peas), (07.) other crops (07.1 - 07.5: alfalfa, Phacelia, wild mustard, tobacco, sunflowers), (08.1) sown fallow, (08.2) fallow with vegetation, (09) grassland, (10) hedgerows, (11) flowing water, (12) streets, (13) settlement, (14) water, (15) forests, (16) urban park area, (17) garden land, (18) orchard meadows and (19) calcareous grasslands. Within each landscape we calculated the percentage area occupied by each habitat type. In this study we reduced the annual habitat types to one category, arable land. Hedgerows, fallows, grassland (grassland, orchard meadows and calcareous grasslands) and garden land were cumulatively defined as semi-natural habitats. Additionally, we calculated for each landscape level the MPAR (Mean Perimeter-Area-Ratio) as a measure of landscape complexity using the ARC $\backslash$ View -Extension PATCH Analyst 2.2.

\section{Bee and wasp assemblages}

Bee and wasp assemblages were record using trap-nests made of common reed. Traps consisted of 150-180, 15-20cm long, internodes of common reed Phragmites australis (Cav.) Trin., put into plastic tubes of $10.5 \mathrm{~cm}$ diameter. A range of reed diameters from 2 to $10 \mathrm{~mm}$ was used (Tscharntke et al. 1998). Altogether, four about $1.5 \mathrm{~m}$ long posts were equipped with four of such reed-filled tubes and exposed in each landscape. Two wooden posts were placed in the center of each study field, one fallow and one rape crop field, in the centre of each landscape. The traps were set up in the field in April and gathered in October. In the laboratory, reed nests were opened and examined for species identification and mortality due to parasitism and predation. After hibernation, adults were recorded and could be identified to the species level. 


\section{Statistical analysis}

The statistical analyses of the data were performed using Statgraphics plus 5.1 (Statgraphics 2001). All data were tested for normality and transformed where necessary. Arcsine-square root transformation was used to achieve normal distribution for percentages (Sokal and Rohlf 1995). We used ANOVA analysis (with Tukey HSD intervals) to compare the results of the different habitat types. The effect of landscape context on bee and wasp assemblages was assessed using simple linear regressions. We analysed each of the twelve nested landscape sectors separately and tested the species richness and abundance of all trap-nesting bees and wasps.

\section{RESULTS}

\section{Landscape context}

Landscape context was characterized by calculating the proportion of arable land (annual habitats), natural habitats and proportion of rapecrop area. MPAR was calculated as a measure of landscape context at twelve spatial scales. At small spatial scales, the dominant habitat type was cropland. For example, the mean percentage of annual habitats in radius of $1500 \mathrm{~m}$ was $54.17 \pm 21.44$ in 2001 . The proportion of semi-natural habitats and the proportion of annual habitat types were significantly correlated at all spatial scales (linear regressions: $p<0.05$ ). Due to this close intercorrelation, we focused our analysis on the proportion of semi-natural habitats. Furthermore, we found no relationship between the proportions of the semi-natural habitats and the proportion of rapecrop fields with MPAR over all scales.

Table 1: Habitat composition in the landscape sectors in Southern Lower Saxony, Germany.

\begin{tabular}{lccc}
\hline \hline Habitat type & Area( \%) & Minimum (\%) & Maximum (\%) \\
\hline Arable land & $54.17 \pm 21.44$ & 15 & 83 \\
Rape crop area & $7.61 \pm 4.15$ & 2.0 & 16.0 \\
Semi natural habitats & $18.5 \pm 10.29$ & 4 & 38 \\
MPAR* & $0.139 \pm 0.028$ & 0.086 & 0.176
\end{tabular}

Note: Means \pm 1 SD, minimum and maximum are given for 18 study sites (landuse data form 2001. Results are given for $1500 \mathrm{~m}$ radius)* MPAR: Mean-Perimeter-Area-Ratio 


\section{Community structure}

Totally, 3237 reed nests were found in the 18 different landscapes. Altogether, we analysed 13726 brood cells including 12862 brood cells of 8 solitary bee species (Hymenoptera: Apidae), 356 brood cells of 4 sphecid wasp species (Hymenoptera: Sphecidae), 281 brood cells of 6 eumenid wasp species (Hymenoptera: Eumeninae), 8 brood cells of one spider wasp specie (Hymenoptera: Pompilidae). Altogether, 2165 brood cells were attacked by 8 natural enemies. Natural enemies include many parasitoids, e.g. ichneumonid and chalcid wasps, but also predators and drosophilid flies (Table 2). The mean rate of parasitism was $15.8 \%$.

\section{Species-habitat type relationship}

Between fallows and rapecrop fields, we found no significant differences with regard to species richness $(\mathrm{N}=34 ; \mathrm{F}=0.05 ; \mathrm{P}>0.832)$, number of nests $(\mathrm{N}=34 ; \mathrm{F}=0.01 ; \mathrm{P}>0.939)$ and number of brood cells $(\mathrm{N}=34 ; \mathrm{F}=0.22 ; \mathrm{P}>0.642)$. Due to these results, data of fallows and oilseed rape fields were pooled.

\section{Species-landscape connectivity}

The percentage of semi-natural habitats and the MPAR as a landscape metric had no effect on the local abundance of species on any spatial scale $(p>0.05$ : example given for $750 \mathrm{~m}$ spatial scale, Figure 1+2). In contrast, we found a negative relationship between the number of brood cells per nest in relation to the proportion of rapecrop fields at the $750 \mathrm{~m}$ scale (Figure 3 ). Additionally, the percentage of rapecrop fields had an positive effect on the number of nests of Osmia rufa (Figure 4). However, we didn't find other significant relationships between the results of the examined species assemblages and the calculated landscape metrics at any spatial scale. 
Table 2: Trap-nesting bees, wasps and their natural enemies from 18 study sites

\begin{tabular}{|c|c|c|c|c|c|c|}
\hline Family & Genus & Species & $\begin{array}{l}\text { Number of } \\
\text { brood cells }\end{array}$ & $\begin{array}{l}\text { Colonised } \\
\text { sites (of } 18 \text { ) }\end{array}$ & $\begin{array}{l}\text { Percentage } \\
\text { parasitised } \\
\text { brood cells }\end{array}$ & Natural enemies \\
\hline \multirow[t]{13}{*}{ Apidae } & \multirow[t]{4}{*}{ Osmia } & rufa (Linnaeaus 1758) & 11899 & 18 & 17 & Cacoxenus indagator (Loew 1858; Diptera, Drosophilidae), \\
\hline & & leaiana (/Kirby 1802) & 142 & 3 & 5.6 & Monodontomerus spp. (Torymidae) \\
\hline & & brevicornis (Fabricius 1798) & 299 & 5 & 4.4 & Megatoma undata (Linnaeus 1758; Erotylidae) \\
\hline & & sp. & 216 & 7 & 1.9 & \\
\hline & \multirow[t]{2}{*}{ Hylaeus } & \multirow[t]{2}{*}{ communis (Nylander 1852) } & 42 & 4 & 7.1 & Gasteruption assectator (Linnae 1758; Hymenoptera Gasteruptionidae) \\
\hline & & & 84 & 10 & 1.2 & Coelopencyrtus arenarius (Erdös 1957; Hymenoptera, Encyrtidae) \\
\hline & \multirow[t]{3}{*}{ Megachile } & lapponica (Thompson 1872) & 6 & 1 & - & - \\
\hline & & versicolor (Smith 1844) & 40 & 1 & - & - \\
\hline & & sp. & 57 & 4 & 19.3 & Mellitobia acasta (Walker 1839; Hyenoptera, Eulophidae) \\
\hline & \multirow[t]{2}{*}{ Heriades } & truncorum (Linnaeus 1758) & 28 & 2 & - & - \\
\hline & & sp. & 30 & 4 & - & - \\
\hline & \multirow[t]{2}{*}{ Chelostoma } & rapunculi (Lepeletier 1841) & 12 & 2 & - & - \\
\hline & & sp. & 7 & 1 & - & - \\
\hline \multirow[t]{4}{*}{ Sphecidae } & \multirow[t]{3}{*}{ Trypoxylon } & figulus (Linnaeus 1758) & 152 & 4 & 8.6 & Chrysis cyanea (Linnaeus 1758; Hymenoptera, Chrysididae) \\
\hline & & medium (de Baeument 1945) & 12 & 2 & 8.3 & Megatoma undata (Linnaeus 1758; Erotylidae) \\
\hline & & $\begin{array}{l}\text { clavicerum (Lepeletier \& Serville } \\
1825)\end{array}$ & 102 & 5 & 4.9 & Megatoma undata (Linnaeus 1758; Erotylidae) \\
\hline & Passaloecus & $\begin{array}{l}\text { sp. } \\
\text { corniger (Shuckard 1837). }\end{array}$ & 90 & 10 & 9.5 & Chrysis cyanea (Linnaeus 1761; Hymenoptera, Chrysididae) \\
\hline \multirow[t]{8}{*}{ Eumeninae } & \multirow[t]{5}{*}{ Ancistrocreus } & antilope (Panzer 1798) & 46 & 3 & - & - \\
\hline & & trifasciatus (Muller 1776) & 21 & 3 & - & - \\
\hline & & gazella (Panzer 1798) & 119 & 6 & 2.5 & Chrysis ignita (Linnaeus 1806; Hymenoptera, Chrysididae) \\
\hline & & nigricornis (Curtis 1826) & 86 & 8 & 2.4 & Chrysis ignita (Linnaeus 1806; Hymenoptera, Chrysididae) \\
\hline & & sp. & 186 & 9 & 13.4 & $\begin{array}{l}\text { Mellitaobia acasta (Walker 1839; Hyenoptera, Eulophidae), Chrysis } \\
\text { cyanea (Linnaeus 1761; Hymenoptera, Chrysididae) }\end{array}$ \\
\hline & \multirow[t]{3}{*}{ Symmorphus } & gracillis (Brulle 1832) & 2 & 2 & - & - \\
\hline & & bifasciatus (Linnaeus 1761) & 7 & 1 & - & - \\
\hline & & sp. & 33 & 1 & - & - \\
\hline Pompilidae & Auplopus & carbonarius (Scopoli 1763) & 8 & 1 & - & - \\
\hline
\end{tabular}



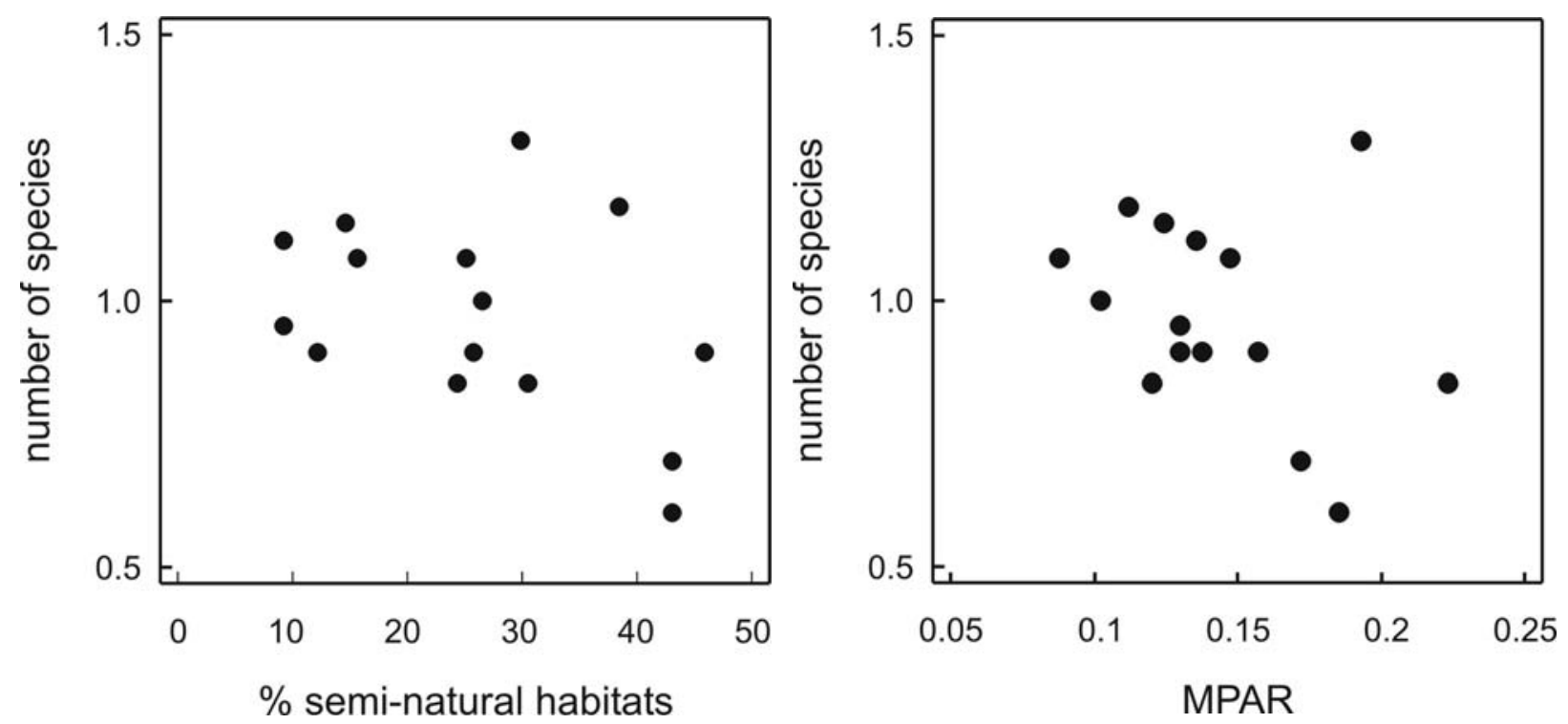

Figure 1: Relationship between the proportion of semi- Figure 2: Relationship between the proportion of seminatural habitats and species richness at $750 \mathrm{~m}$ spatial natural habitats and species richness at $750 \mathrm{~m}$ spatial scale (linear correlation: $\underline{Y}=0.916-$ scale (linear correlation: $\mathrm{Y}=0.963$ $0.001 * \operatorname{asin}\left(\operatorname{sqrt}(X / 100), \underline{\mathrm{F}}=0.04, \underline{\mathrm{P}}=0.836, \underline{\mathrm{R}^{2}}=0.278\right) . \quad 0.532 * \operatorname{asin}\left(\operatorname{sqrt}(\mathrm{X} / 100), \mathrm{F}=0.11, \mathrm{P}=0.746, \mathrm{R}^{2}=0.676\right)$.
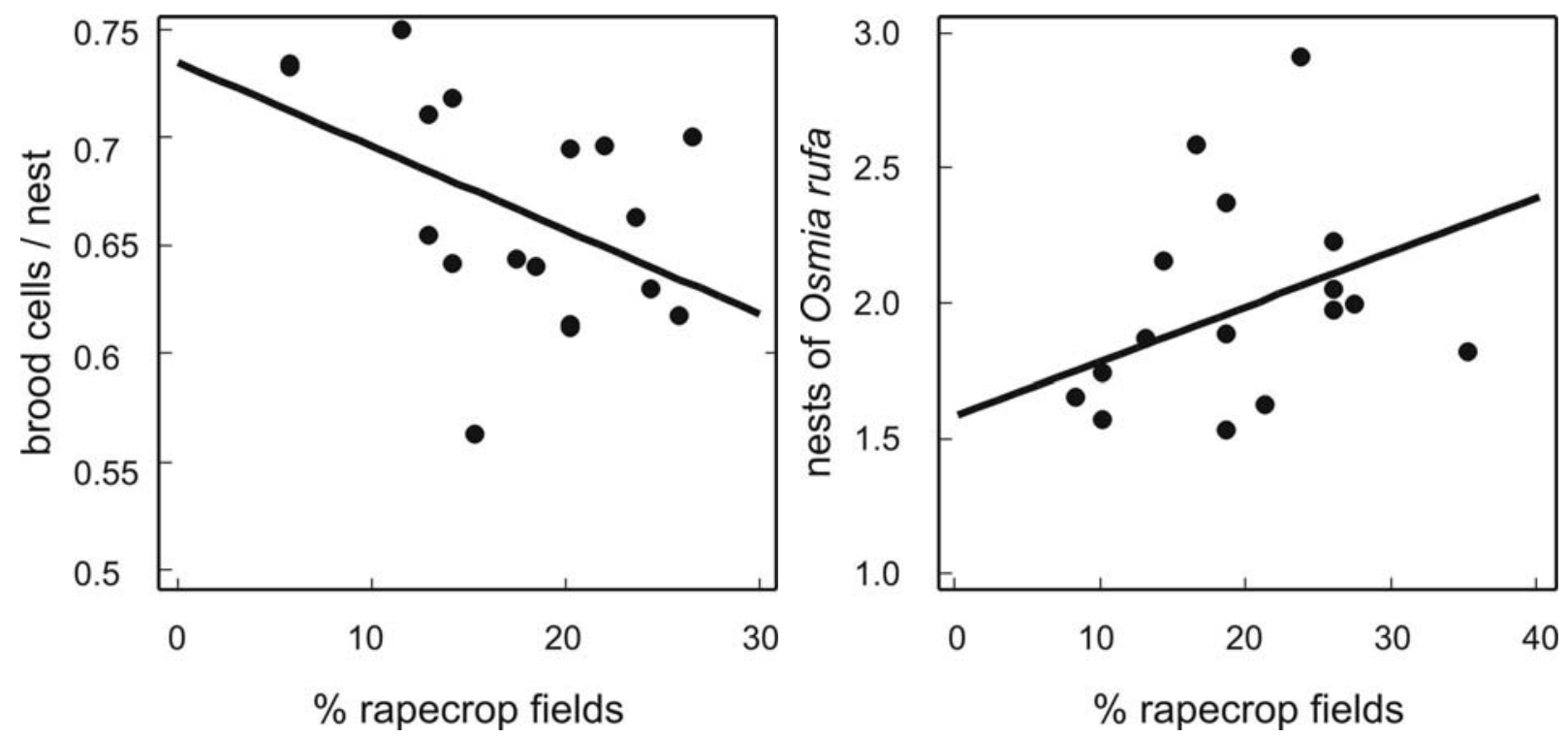

Figure 3: Relationship between the proportion of rape- Figure 4: Relationship between the proportion of rapecrop fields and brood cells per nest at $750 \mathrm{~m}$ spatial crop fields and nests of Osmia rufa at $500 \mathrm{~m}$ spatial scale (linear correlation: $\underline{Y}=0.735$ - scale (linear correlation: $\underline{Y}=1.582+$ $0.004 * \operatorname{asin}\left(\operatorname{sqrt}(\mathrm{X} / 100), \underline{\mathrm{F}}=4.48, \underline{\mathrm{P}}=0.05, \underline{\mathrm{R}^{2}}=21.88\right) . \quad 0.02 * \operatorname{asin}\left(\operatorname{sqrt}(\mathrm{X} / 100), \underline{\mathrm{F}}=4.6, \underline{\mathrm{P}}<0.05, \underline{\mathrm{R}^{2}}=22.31\right)$. 


\section{DISCUSSION}

Human intervention in the landscape complex can cause, on local and regional scales, habitat loss, species loss and instability of ecosystems (Saunders et al. 1991, Ney-Nifle \& Mangel 2000). Agricultural intensification may reduce the diversity and abundance of many organisms (Rosenzweig 1995, Sotherton 1998) and thus endangers crop pollination (Free 1993, Kremen et al. 2002). A recent topic in agro-ecology and landscape ecology is the understanding of species richness and their distribution on regional scales (Kareiva \& Wennergren 1995, Steffan-Dewenter 2003, Holland et al. 2004). In our study we analysed wild bee communities in intensively used agricultural landscapes. Our central focus was to measure the effect and the importance of local habitat type and the influence of the surrounding landscapes on species composition of wild bee communities by using three landscape metrics at twelve spatial scales, the MPAR (Mean-Perimeter-Area-Ratio) as a measure for landscape structure, the percentage of semi-natural habitats and the percentage of rapecrop area in a landscape as measures for habitat composition.

Generally, local factors such as habitat area and habitat age can affect species composition and diversity of plants and insect communities (Steffan-Dewenter \& Tscharntke 2001, Goverde et al. 2002). Near-natural habitats like fallows may enhance species diversity and abundance of trap-nesting bees (Tscharntke et al. 1998, Steffan-Dewenter \& Tscharntke 2001). We assumed that wild bee communities on fallows and on the edges of rapecrop fields would differ in species composition and abundance. In contrast to our expectations, we found an almost identical number of solitary wild bees, wasps and their natural enemies (1) on fallows and on the edges of rapecrop fields and (2) in all 18 study sites, independent of the landscape structure and the percentage of semi-natural habitats and at any spatial scale. Other studies could show that an increasing percentage of semi-natural habitats had a positive influence on species diversity (Mand et al. 2002, Steffan-Dewenter et al. 2002), especially on the abundance of flower-visiting bees (Bürger et al. 2004).

Agricultural landscapes are characterized by intensive land use including the usage of pesticide and high habitat disturbance. Therefore, agricultural areas and their field edges are characterised by strong disturbance. This could explain the low number of brood cells per nest and the higher nest number in landscapes with high portion of oilseed rape. Due to crop rotation, organisms must adapt permanently to changes of spatial arrangements of crops reflecting potential food resources. Therefore, intensively used agricultural landscapes contain 
a high number of generalists (Krauss et al. 2004). In contrast to these results, other studies in the same region found a higher abundance of flower-visiting bees (solitary wild bees, bumble bees and honey bees) with increasing percentage of semi-natural habitats (Bürger et al. 2004). This is in line with expectation that solitary wild bees depend on sufficient food resources and nesting sites (Gathmann \& Tscharntke 1999). These resources should occur within the spatial perception of solitary wild bees. The spatial scale at which species interact with landscape patterns depends on foraging distances (Keitt et al. 1997). In this study, we found the strongest effects on small spatial scales confirming other results that solitary wild bees interact with surrounding landscape on small spatial scales (Steffan-Dewenter et al. 2002). Rapecrop fields provide mass food resources that can enhance and support bumblebee populations (Westphal et al. 2003). The destruction of suitable nesting sites is a limiting factor for the local establishment of many bee communities (Klein et al. 2003). Generally, structurally rich landscapes contain sufficient natural food resources to support a high diversity of native bees (Banaszak 1992).

In conclusion we expect, that mass food resources combined with a high percentage of seminatural perennial habitats should lead to a higher bee diversity. However, mass resources provided by oilseed rape may enhance social bees (Westphal et al. 2003), but not solitary bees (this study). There is a need for experimental studies that take into account the real complexity of the surrounding landscape in intensively used agricultural landscape to explain the structure of wild bee communities.

\section{ACKNOLEDGEMENTS}

We greatly thank Carsten Thies and Doreen Gabriel for helpful comments on the manuscript. This work was supported by the Scholarship Program of the German Federal Environmental Foundation.

\section{REFERENCES}

Allen-Wardell, G.,Bernhardt, P., Bitner, R., Burquez, A., Buchmann, S., Cane, J., Cox, P.A., Dalton, V., Feinsinger, P., Ingram, M., Inouye, D., Jones, C.E., Kennedy, K., Kevan, P., Koopowitz, H., Medellin, R., Medellin-Morales, S., Nabhan, G.P., Pavlik, B., Tepedino, V., Torchio, P., Walker, S., (1998): The potential consequences of 
pollinator declines on the conservation of biodiversity and stability of food crop fields. Conservation Biology 12, 1-11.

Antrop, M. (2000): Background concepts for integrated landscape analysis. Agriculture, Ecosystems and Environment 77: 17-28.

Banaszak, J. (1992): Strategy for conservation of wild bees in an agricultural landscape. Agriculture, Ecosystems and Environment 40 (1-4): 179-192.

Bierregard, R., Lovejoy, T., Kapos, V., Dos Santos, A., Hutchings, R. (1992): The biological dynamics of tropical rainforest fragments. Bio-Science 42, 859-866.

Bürger, C., Steffan-Dewenter, I., Tscharntke, T. (2004): Pollination of oilseed rape in differently structured landscapes. (submitted)

Cunningham, S. (2000): Depressed pollination in habitat fragments causes low fruit set. Proceedings of the Royal Society of London Series B 267: 1149-1152.

De la Pena, N.M., Butet, A., Delettre, Y., Morant, P., Burelm, F.(2003): Landscape context and carabid beetles (Coleoptera : Carabidae) communities of hedgerows in western France; Agriculture, Ecosystems \& Environment 94 (1), S.59-72.

Free, J.B. (1993): Insect pollination of crops, Academic Press, London, UK.

Gathmann, A. \& Tscharntke, T. (1999): Bienen, Wespen und ihre Gegenspieler in der Agrarlandschaft: Habitatbewertung und Populationsentwicklung. Verhandlungen der Gesellschaft für Ökologie Bd. 29, 1999: 213-218.

Goverde M, Schweizer K, Baur B, Erhardt A (2002): Small-scale habitat fragmentation effects on pollinator behaviour: experimental evidence from the bumblebee Bombus veteranus on calcareous grasslands. Biological Conservation 104 (3): 293-299.

Gustafson, E.J. (1998): Quantifying landscape spatial pattern: What is the state of the art? Ecosystems 1:143-156.

Hanski, I. (1999): Habitat connectivity, habitat continuity and metapopulations in dynamic landscapes. Oikos 87: 209-219.

Harrison, S., Bruna, A. (1999): Habitat fragmentation and large-scale conversation: What do we know for sure? Ecography 22: 225-232.

Holland, J.D., Bert, D.G., Fahrig, L. (2004): Determining the spatial scale of species' response to habitat. Bioscience 54 (3): 227-233.

Kareiva, P. , Wennergren, U. (1995): Connecting landscape patterns to ecosystem and population processes. Nature 373: 299-302.

Keitt, T. H., D. L. Urban, and B. T. Milne. (1997): Detecting critical scales in fragmented landscapes. Conservation Ecology 1(1): http://www. consecol.org/vol1/iss1/art4. 
Klein, A., Steffan-Dewenter, I., Tscharntke, T. (2003): Fruit set of Coffea arabica depends on the diversity of pollinating bees. Proceedings of the Royal Society of London, Series B 270: 955-961.

Kleyer, M., Kaule, G., Settele, J. (1996): Landscape fragmentation and landscape planing, with a focus of Germany. Kluwer academic Publishers: 138-151.

Krauss, J., Klein, A.-M., Steffan-Dewenter, I., Tscharntke, T. (2004): Effects of habitat area, isolation, and landscape diversity on plant species richness of calcareous grasslands. Biodiversity and Conservation 13: $1427-1439$.

Kremen, C., Williams, N.M., Thorp, R.W.(2002): Crop pollination from native bees at risk from agricultural intensification. Proceedings of the National Academy of Science of the United States of America 99 (26): 16812-16816.

Mand, M., Mand, R., Williams, I.H. (2002): Bumblebees in the agricultural landscape of Estonia. Agriculture, Ecosystems \& Environment 89 (1-2): 69-76.

Matthies, D., Bräuer, I., Maibom, W., Tscharntke, T. (2004): Population size and the risk of local extinction: empirical evidence from rare plants, OIKOS 105: 481-488.

Menalled, F.D., Marino, P.C., Gage, S.H., Landis, D.A. (1999): Does agriculture landscape context affect parasitism and parasitoid diversity? Ecological Applications 9 (2): 634641.

Ney-Nifle, M., Mangel, M. (2000): Habitat loss and changes in the species-area relationship. Conservation Biology 14 (3): 893-898.

PATCH-Analyst (2000): Utility for spatial analysis and attribute modelling of landscape patches. Version 2.2. Sustainable Forest Management Network (NCE), and Centre for Northern Forest Ecosystem Research (OMNR).

Rathcke, B. J., E. S. Jules. (1993): Habitat fragmentation and plant-pollinator interactions. Current Science 65:273-77.

Rosenzweig, M.L. (1995): Species diversity in space and time. Cambridge University Press, Cambridge, UK.

Saunders, D.A., Hobbs, R.J., Margules, C.R. (1991): Biological consequences of ecosystem fragmentation: a review; in Conservation Biology 5(1): 18-31.

Sokal, R.R., and Rohlf, F. (1995): Biometry. Freeman, New York, New York, USA.

STATGRAPHICS (2001): Statgraphics plus for Windows, version 5.1. Manugistics, Rockville, Maryland, USA. 
Steffan-Dewenter, I. (2003): The importance of habitat area and landscape context for species richness of bees and wasps in fragmented orchard meadows. Conservation Biology 17(4): 1036-1044.

Steffan-Dewenter, I. (2002): Landscape context effects trap-nesting bees, wasps and theirs natural enemies. Ecological Entomology 27: 631-637

Steffan-Dewenter, I., Münzenberg, U., Buerger, C., Thies, C., Tscharntke, T. (2002): Scaledependent effects of landscape structure on three pollinator guilds. Ecology 83, 14211432.

Steffan-Dewenter, I., Münzenberg, U., Tscharntke, T. (2001): Pollination, seed-set und seed predation on a landscape scale. Proceedings of the Royal Society London, Series B $268,1685-1690$.

Steffan-Dewenter, I., Tscharntke, T. (2001): Succession of bee communities on fallows. Ecography 24: 83-93.

Steffan-Dewenter, I. \& Tscharntke, T. (1999): Effects of habitat isolation on pollinator communities and seed set. Oecologia 121: 432-440.

Sotherton, N.W. (1998): Land use changes and the decline of farmland wildlife: An appraisal of the set-aside approach. Biological Conservation 83 (3): 259-268.

Thies, C. \& Tscharntke, T. (1999): Landscape context and biological control in agroecosystems. Science 285: 893-895.

Tscharntke, T. , Gathmann, A., Steffan-Dewenter, I. (1998): Bioindication using trap-nesting bees, wasps, and parasitoids: community structure and interactions. Journal of Applied Ecology 35: 708-719.

Walz, U. (1999): Erfassung und Bewertung der Landnutzungsstruktur, in "Erfassung und Bewertung der Landschaftsstruktur - Auswertung mit GIS und Fernerkundung”, Hrsg. WALZ, U.; Dresden, S. 1-8.

Weibull, A.C., Ostman, O., Granqvist, A. (2003): Species richness in agroecosystems: the effect of landscape, habitat and farm management. Biodiversity and Conservation 12 (7): 1335-1355.

Westphal, C., Steffan-Dewenter, I., Tscharntke, T. (2003): Mass flowering crops enhance pollinator densities at a landscape scale. Ecology Letters 6: 961-965. 


\section{Scale-dependent effects of landscape context on three pollinator guilds}

\section{ABSTRACT}

Most ecological processes and interactions depend on scales much larger than a single habitat, and therefore it is important to link spatial patterns and ecological processes at a landscape scale. Here, we analysed the effects of landscape context on the distribution of bees (Hymenoptera: Apoidea) at multiple spatial scales with respect to the following hypotheses: (1) Local abundance and diversity of bees increase with increasing proportion of the surrounding semi-natural habitats. (2) Solitary wild bees, bumble bees, and honey bees respond to landscape context at different spatial scales. We selected 15 landscape sectors and determined the percentage of semi-natural habitats and the diversity of habitat types at eight spatial scales (radius 250-3000 m) by field inspections and analyses of vegetation maps using two Geographic Information Systems. The percentage of semi-natural habitats varied between $1.4 \%$ and $28 \%$. In the center of each landscape sector a patch of potted flowering plants (four perennial and two annual species) was placed in the same habitat type, a grassy field margin adjacent to cereal fields. In all, 865 wild bee individuals and 467 honey bees were observed and an additional 475 individuals were caught for species identification. Species richness and abundance of solitary wild bees showed a close positive correlation with the percentage of semi-natural habitats at small scales up to $750 \mathrm{~m}$, whereas bumble bees and honey bees did not respond to landscape context at these scales. In contrast, honey bees were correlated with landscape context at large scales. The densities of flower-visiting honey bees even increased with decreasing proportion of semi-natural habitats at a radius of $3000 \mathrm{~m}$. We are not aware of any empirical studies showing contrasting foraging patterns related to landscape context at different spatial scales. We conclude (1) that local landscape destruction affects solitary wild bees more than social bees, possibly changing mutualistic plant-pollinator and competitive wild bees- honey bees interactions and (2) that only analyses of multiple spatial scales may detect the importance of the landscape context for local pollinator communities. 


\section{Key words}

Bees; biotic interactions; community structure; connectivity; habitat fragmentation; landscape ecology; pollination; spatial scales; species diversity.

\section{INTRODUCTION}

Habitat fragmentation and destruction have been recognized as major threats to biodiversity (e.g., Saunders et al. 1991, Harrison and Bruna 1999). Decreasing size and increasing isolation of habitat patches lead to a decline in species richness and abundance as well as to changes in community structure (Holt et al. 1999, Connor et al. 2000, Debinski and Holt 2000, Steffan-Dewenter and Tscharntke 2000a). This process of habitat fragmentation and destruction may greatly change the landscape structure and local ecosystem functions (Kareiva and Wennergren 1995). Most ecological processes and interactions depend on spatial scales much larger than a single habitat patch, and therefore, ecologists have become increasingly aware of the importance of linking spatial patterns and ecological processes at a landscape scale (Turner and Gardner 1991, Kareiva and Wennergren 1995, Gustafson 1998, Wiegand et al. 1999). Changes in landscape structure can be characterized by the proportion of suitable habitat (Andrén 1994), the diversity of habitats, and the size and spatial arrangement of habitats in a landscape (Gustafson 1998).

The analysis of ecological processes on large spatial scales is the subject of three more or less separated disciplines, metapopulation ecology, theoretical ecology, and landscape ecology (Hanski 1998). Metapopulation ecology provides a good framework to understand population dynamics as a consequence of migration, colonization, and extinction in spatially structured habitats. Theoretical ecologists have developed neutral landscape models and individualbased spatially explicit landscape models that emphasize the importance of analysing different spatial scales (e.g., Keitt et al. 1997, Wiegand et al. 1999). Landscape ecologists are concerned with the description and analyses of real landscapes, using a variety of methods and parameters to quantify landscape structure (e.g., Turner and Gardner 1991, Cain et al. 1997, Gustafson 1998). Although there is an overlap between these disciplines, the needed synthesis has yet to emerge (Turner et al. 2001). Furthermore, community studies are mostly focused on habitat fragments and more or less ignore the importance of the surrounding matrix (Ricketts 2001, Tscharntke et al. 2002). Few empirical data provide an insight into 
how landscape structure determines the diversity and interactions of local communities and which spatial scale matters. Forest fragmentation affects four parasitoids of the forest tent caterpillar at different spatial scales depending on body size (Roland and Taylor 1997). Landscape structure affects biological control of oilseed rape pollen beetles (Thies and Tscharntke 1999) but not parasitism of the armyworm (Menalled et al. 1999). Bird diversity is determined by habitat diversity at intermediate spatial scales, while at large biogeographical scales abiotic factors are more important (Böhning-Gaese 1997). Functional groups of trees are related to landscape structure at different spatial scales (Metzger 2000). These studies indicate that particular patterns and processes occur at particular spatial scales and that the spatial scale at which organisms interact may depend on both the landscape type and the species' traits.

An important element of landscape structure is the degree to which a landscape facilitates or impedes movement of organisms among resource patches, i.e., connectivity (Tischendorf and Fahrig 2000). Structural connectivity by corridors maintains species richness and increases local population abundance in the fragmented landscapes of a microecosystem (Gilbert et al. 1998, Gonzales et al. 1998). Functional connectivity is a scale-dependent feature that depends on the spatial scale at which individuals perceive and interact with landscape structure by dispersal (Keitt et al. 1997, With et al. 1999). This scale is difficult to assess a priori and has to be identified by testing for a correlation between the population-dynamic features of interest and landscape characteristics at different spatial scales (Kareiva 1990, Wiegand et al. 1999).

In this study we analysed the effects of landscape context on the diversity and abundance of bees (Hymenoptera: Apoidea) at different spatial scales. Bees are an important functional group due to their mutualistic interactions with plants (Allen-Wardell et al. 1998). The possible negative effects of habitat fragmentation and isolation on plant-pollinator interactions have attracted much attention in the last years (e.g., Rathcke and Jules 1993, Kearns et al. 1998), and some evidence exists that small or isolated plant populations receive fewer flower visits and may suffer from pollinator limitation (Jennersten 1988, Aizen and Feinsinger 1994, Steffan-Dewenter and Tscharntke 1999, Cunningham 2000). Almost nothing is known about the relation between landscape composition and pollinator diversity.

Bees can be subdivided into three pollinator guilds: solitary wild bees, social wild bumble bees, and managed honey bees. These groups greatly differ with respect to foraging distances and life history traits (Eickwort and Ginsberg 1980, Dramstad 1996, Osborne et al. 1999). The 
landscape in central Europe has been greatly changed by humans for several thousand years and almost no natural, primary bee habitats such as moors, inland dunes, or floodplains of rivers exist (Klemm 1996, Küster 1999). Today, native bees mainly depend on man-made semi-natural habitats such as calcareous grasslands, meadows, and fallows, which developed by extensive land use (Osborne et al. 1991). Many bee species have specific requirements with respect to flowers providing pollen and nectar, nest sites, and building material, and these resources may occur spatially separated in different habitats within their foraging range (Westrich 1996). Therefore, not only the proportion of suitable habitat but also the diversity of habitat types may be important for the occurrence of a bee species in a landscape sector.

To standardize recording of pollinators, an experimental approach was used that is analogous to the "hybrid patch-landscape scale"' approach suggested recently by theoretical ecologists (Tischendorf and Fahrig 2000). They recommend the use of non-overlapping landscapes as study units and the sampling of a single patch in the centre of each landscape. Each single data point is obtained from a separate landscape and therefore replicated at the landscape scale thus maintaining independence (Tischendorf and Fahrig 2000). Here, we selected 15 landscape sectors using a gradient from structurally simple to structurally rich landscapes. In the centre of each landscape a patch of flowering plants was placed in the same local habitat (grassy field margins adjacent to cereal fields) to measure the diversity and abundance of bees associated with landscape context at multiple spatial scales. We expected (1) that abundance and diversity of bees increase with increasing percentage of semi-natural habitats in a landscape and (2) that solitary bees, bumble bees, and honey bees respond to landscape context to a different extent and at different spatial scales.

\section{MATERIAL AND METHODS}

\section{Study region and study sites}

The study was conducted in 1997 in southern Lower Saxony, Germany, around Göttingen. The study region is characterized by intensively managed agricultural areas and patchily distributed fragments of forests and several other semi-natural habitat types (Fig. 1a; Plate 1). The average temperature during the study period from June to August was $19.7^{\circ} \mathrm{C}\left(2.4^{\circ} \mathrm{C}\right.$ above the long-term mean), the rainfall was $223.8 \mathrm{~mm}$ (17.6 $\mathrm{mm}$ above the long-term mean), and the duration of sunshine was $699.9 \mathrm{~h}$ (96.5 h above the long-term mean; data from the meteorological station in Hanover). 
We selected 15 study sites that covered all levels of landscape context in the study area from structurally simple to structurally rich landscapes. Study sites with different types of landscape structure were randomly distributed to prevent possible autocorrelation and correlations between landscape structure and abiotic factors (Fig. 1a). The effects of landscape context on bee visitation to the experimental plots were analysed at eight radii of $250,500,750,1000,1500,2000,2500$, and $3000 \mathrm{~m}$, which represented a nested set of spatial scales (Fig. 1b). These scales were chosen due to known flight and forage distances of several hundred meters for solitary bees and up to $3 \mathrm{~km}$ for honey bees (Eickwort and Ginsberg 1980, Visscher and Seeley 1982, Dramstad 1996, Osborne et al. 1999, Steffan-Dewenter and Tscharntke 2000b).

\section{Quantifying landscape context}

Landscape context was quantified using two different methods. First, for the three smallest scales (radius 250-750 m), intensive field inspections were made to quantify the total area of each habitat type in the landscape sector. Field inspections were supported by infrared aerial photographs (1:10 000). The results of field inspections were incorporated into topographical maps with a scale of $1: 5000$. Habitat types were classified according to von Drachenfels (1996) into: arable land; fallow fields and ruderal areas (including field margins); intensively used grasslands; extensively used grasslands (including orchard meadows); calcareous grasslands; hedgerows, forest; water area and settlement area; rock habitats and vegetation along inshore waters (Table 1). Forests were further divided into a core area and forest margins (10 m deep boundary) adjacent to nonforest habitats. To characterize landscape context we calculated for each spatial scale the percentage $\left(p_{i}\right)$ of semi-natural habitats that were expected to represent potential bee habitats (see Table 1) and total habitat diversity using the Shannon-Wiener index (H`s $=\sum$ pi x $\log \left(p_{i}\right)$; Krebs 1989). 
a

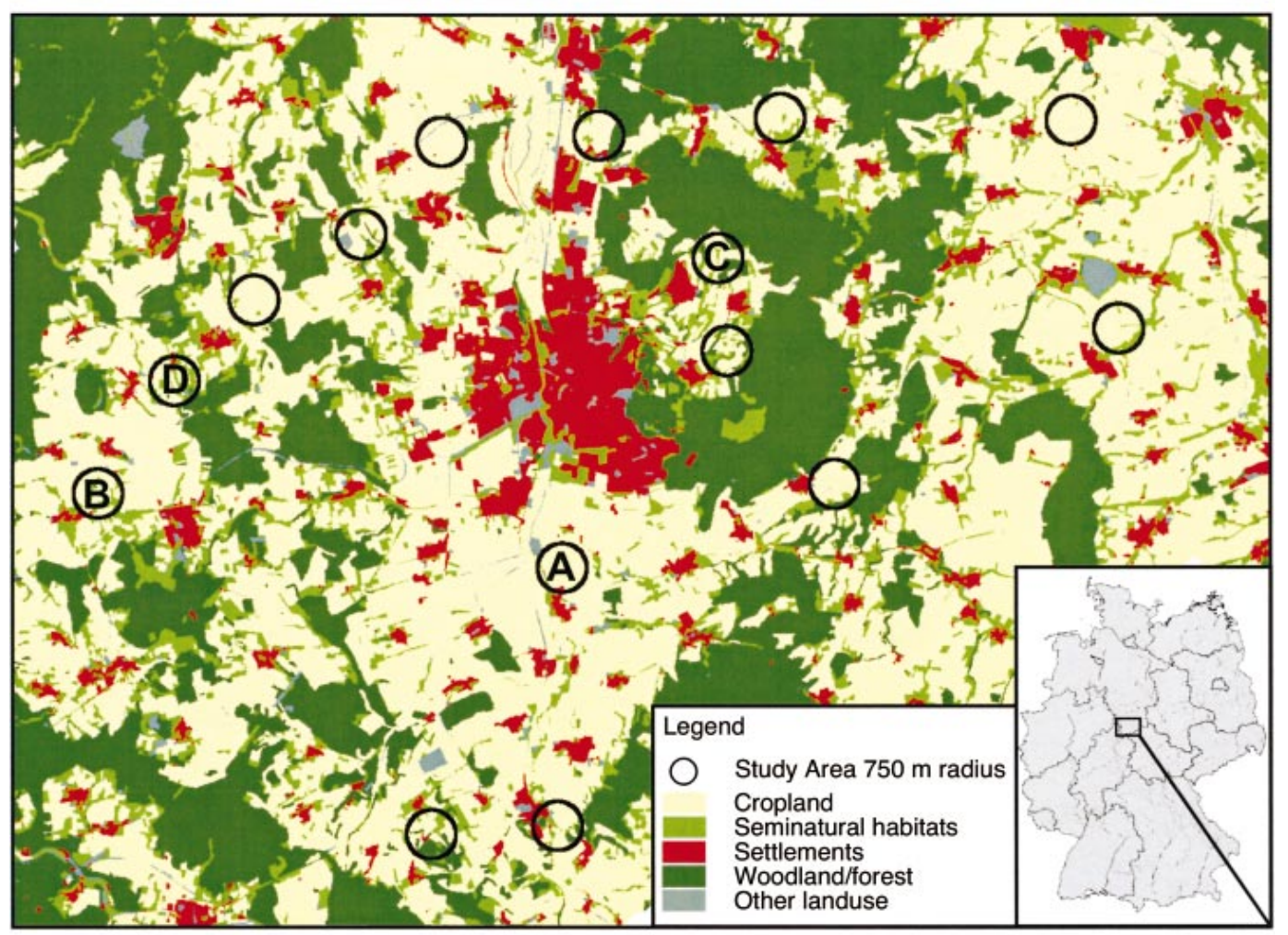

b

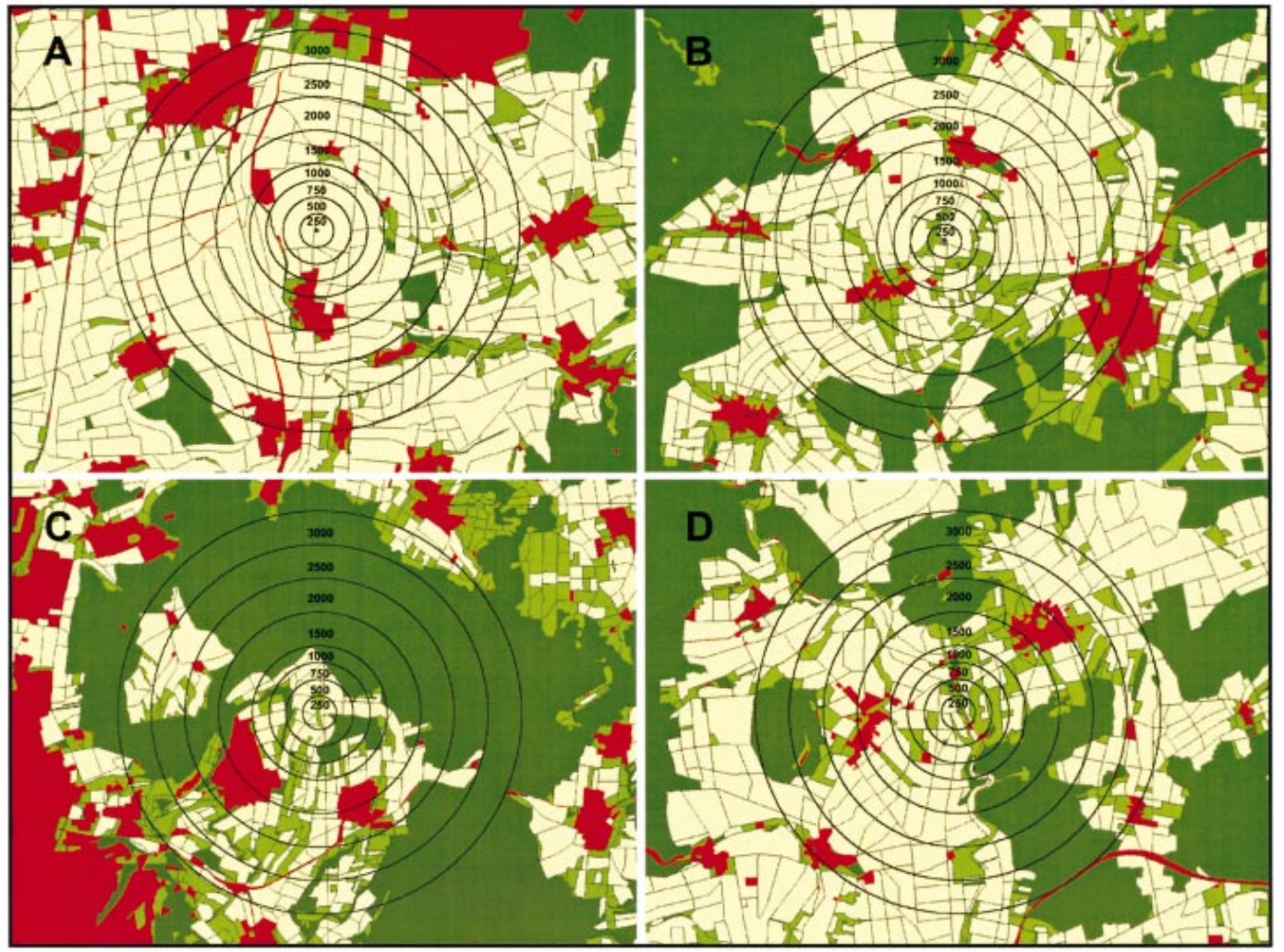

Figure. 1. Study region and study sites in southern Lower Saxony, Germany. (a) Location of the 15 landscape sectors and the distribution of the main habitat types. (b) Four study sites (marked A, B, C, and D in Fig. 1a) with the eight nested spatial scales used in the analyses. 
Second, for all spatial scales (radius 250-3000 m), a less-detailed method was used to quantify landscape structure using existing commercially available, digital maps (ATKISDLM 25/1, 1991-1996; Landesvermessungsamt \& Geobasisinformationen Niedersachsen, Hannover, Germany) covering the habitat types arable land, grassland, hedgerows, garden land, forest, and settlement area (Table 1). For each of the eight nested spatial scales the total area of each habitat type was quantified separately using the Geographic Information Systems ARC/View 3.1 (ESRI Geoinformatik, Hannover, Germany) and TopoL 4.506 (Gesellschaft für digitale Erdbeobachtung und Geoinformationen, Göttingen, Germany). Again, the proportion of semi-natural habitats (grasslands including intensively and extensively used grasslands, calcareous grasslands and orchard meadows, hedgerows, and garden land; see Table 1) and total habitat diversity (Shannon-Wiener index) were calculated for each of the eight spatial scales separately.

\section{Field experiments}

To measure the effect of landscape context on pollinator diversity and abundance independently from soil conditions and habitat quality, we established patches of potted flowering plants in the center of each of the 15 landscape sections (Fig. 1b). To cover a broad spectrum of flower morphology and flowering time we used four perennial plant species, Anthyllis vulneraria (Fabaceae), Campanula rotundifolia, Campanula rapunculoides (Campanulaceae), and Centaurea jacea (Asteraceae), and two annual plant species, Raphanus sativus (Brassicaceae) and Borago officinalis (Boraginaceae). Seeds from wild plant populations were obtained from a commercial seed grower (Conrad Appel, Abteilung Wildpflanzensamen, Darmstadt, Germany). The perennial species were sown in November 1996 in a glasshouse, pricked out in mid-December (Anthyllis vulneraria) and mid-January (Campanula rotundifolia, C. rapunculoides, and Centaurea jacea), respectively, and planted in upper compartments (pots of $3.5 \mathrm{~L}, 24 \mathrm{~cm}$ diameter) with standardized garden soil (Einheitserde Typ T; Archut/Hawita, Vechta, Germany) of larger pots (8.5 L, $24 \mathrm{~cm}$ diameter) in March. The lower part of the pot was used as a water supply $(5 \mathrm{~L})$ and was connected with wicks to the upper part, which contained the garden soil. Annuals were sown in mid-March 1997 (R. sativus) and mid-May (B. officinalis). Two of the experimental plant species were placed into each pot using the following combinations: A. vulneraria with Campanula rotundifolia, $R$. sativus with Centaurea jacea, and Campanula rapunculoides with $B$. officinalis. Four pots of each of the three plant species combinations were placed on grassy 
field margins adjacent to cereal fields in each of the 15 landscapes between 13 and 16 May 1997 to establish experimental patches of flowering plants, i.e., 12 pots per study site and 180 pots altogether. Distance between each conspecific pot was $1 \mathrm{~m}$. To prevent damage by rabbits or deer, the plants were fenced with wire $(6 \mathrm{~m} \times 1.20 \mathrm{~m}, 1 \mathrm{~m}$ height $)$. Depending on weather conditions, plants were watered every 5-10 d.

\section{Flower-visitor observations}

Flower visitation was observed between 0900 and 1700 during June-August 1997 in typical weather conditions, i.e., at least $18^{\circ} \mathrm{C}, 70 \%$ sunshine, and low wind velocity. The four individuals of each plant species were observed simultaneously, recording all flower-visiting insects for $15 \mathrm{~min}$ (Plate 1). Bees were identified to genus level in the field. After each observation period, flower-visiting bees were captured during a further 15-min period for identification in the laboratory. To obtain unbiased data, on each field day, observations were made in different landscape types, and time of day was varied at a given study site for successive observations. The number of observation periods per plant species depended on the flowering period and weather conditions and varied between two and five observations per study site. Altogether 314 flower-visitor record periods (15-min observation and 15-min capture) were made. A. vulneraria flowered between 18 June and 25 July, Campanula rotundifolia between 25 June and 8 August, Campanula rapunculoides between 29 June and 4 August, Centaurea jacea between 29 July and 25 August, and B. officinalis between 6 and 25 August 1997. R. sativus plants could not be observed, because they did not grow well and developed only few flowers.
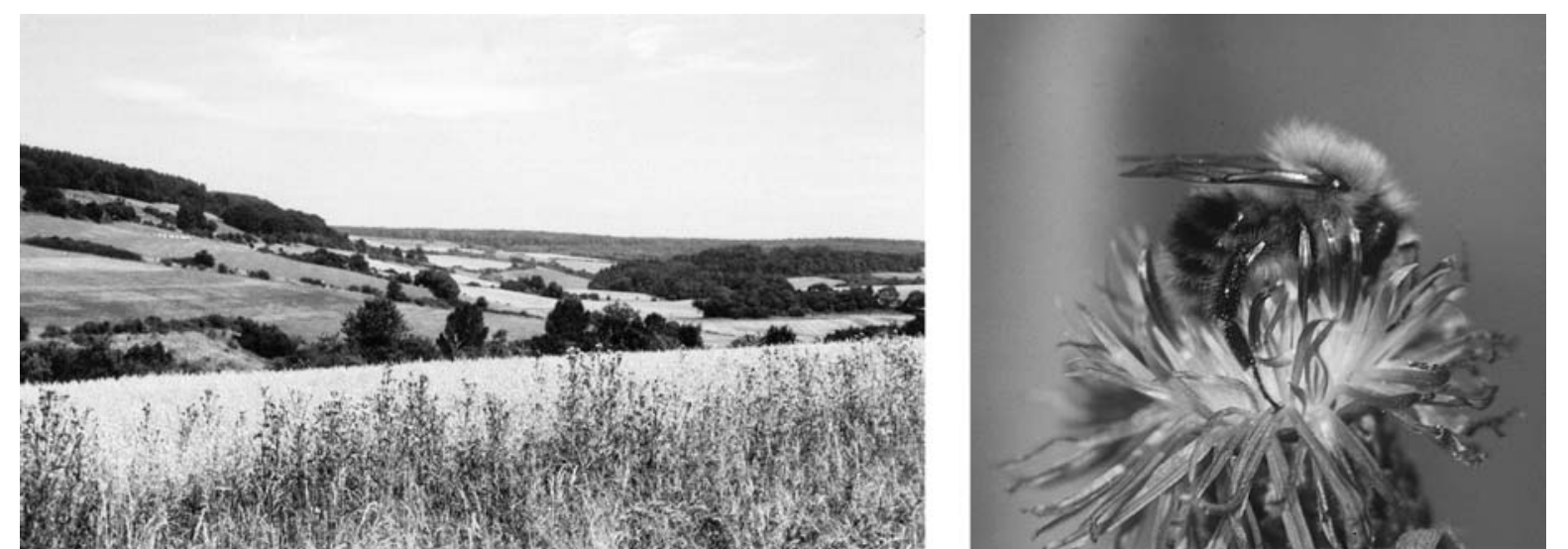

Plate 1. (Left) A structurally rich landscape sector $5 \mathrm{~km}$ northeast of Göttingen, Germany (C in fig. 1a). Photograph by Carsten Thies. (Right) Flower-visiting bumble bee (Bombus pascuorum)on Centaurea jacea. Photograph by Ute Münzenberg. 


\section{Statistical analyses}

The statistical analyses of the data were performed using Statgraphics plus for Windows 2.1 (Statgraphics 1995). All data were tested for normality and transformed where necessary. Arcsine transformation ( $\arcsin \sqrt{ } p$ where $p$ is a proportion) was used to achieve normal distribution for percentages (Sokal and Rohlf 1995).

Pollinator abundance per study site was the mean number of observed flower-visiting bee individuals per $15 \mathrm{~min}$ over all five plant species. Species richness per landscape represents the total number of bee species captured in the second part of each observation period. The effect of landscape context on pollinators was assessed using simple linear regressions. We analysed each of the eight nested landscape sectors (radius from 250 to $3000 \mathrm{~m}$ ) separately and tested for each radius how the species richness and abundance of all wild bees, solitary wild bees, bumble bees, and honey bees responded to the proportion of semi-natural habitats. Mean individual body size of solitary wild bees was calculated using a database of German bee species (Steffan-Dewenter and Tscharntke 1999). Scatterplots were used to illustrate scale-dependent changes of $r^{2}$ values for the correlation between landscape context and pollinators. Arithmetic means $\pm 1 \mathrm{SD}$ are given in the text.

Table 1. Habitat composition in the landscape sectors in Southern Lower Saxony, Germany.

\begin{tabular}{lccc}
\hline \multicolumn{1}{c}{ Habitat type } & Area (\%) & Minimum (\%) & Maximum (\%) \\
\hline a) Quantification based on own field inspections (radius $750 \mathrm{~m})$ & & \\
Arable land & $77.98 \pm 17.17$ & 49.9 & 96.76 \\
Calcareous grasslands $\dagger$ & $3.17 \pm 5.36$ & 0 & 20.43 \\
Extensive grasslands $\dagger$ & $2.88 \pm 3.68$ & 0 & 10.66 \\
Intensive grasslands & $2.35 \pm 1.97$ & 0 & 6.44 \\
Fallows and ruderal areas $\dagger$ & $2.54 \pm 2.10$ & 0 & 6.16 \\
Hedgerows $\dagger$ & $1.15 \pm 1.58$ & 0 & 5.82 \\
Forests & $8.46 \pm 9.95$ & 0 & 28.01 \\
Forest margins $\dagger$ & $0.54 \pm 0.67$ & 0 & 2.20 \\
Vegetation along inshore waters $\dagger$ & $0.53 \pm 0.46$ & 0 & 1.35 \\
Rock habitats $\dagger$ & $0.04 \pm 0.11$ & 0 & 0.36 \\
Settlement & $0.33 \pm 0.11$ & 0.09 & 0.49 \\
& & & \\
b) Quantification based on digital thematic maps (radius $750 \mathrm{~m})$ & & 98.33 \\
Arable land & $74.63 \pm 17.08$ & 50.86 & 36.58 \\
Grasslands $\dagger$ & $12.0 \pm 9.75$ & 0 & 1.37 \\
Hedgerows $\dagger$ & $0.18 \pm 0.42$ & 0 & 29.28 \\
Forests & $9.61 \pm 11.23$ & 0 & 0.48 \\
Garden land $\dagger$ & $0.05 \pm 0.13$ & 0 & 12.67 \\
Settlement & $2.15 \pm 3.34$ & 0 & \\
\hline
\end{tabular}

Note: Means $\pm 1 \mathrm{SD}$, minimum, and maximum are given for 15 study sites.

$\uparrow$ Habitat types classified as semi-natural habitat. 


\section{RESULTS}

\section{Characteristics of landscape context}

Landscape context was characterized by the proportion of each habitat type and by the diversity of habitat types at eight spatial scales. Field inspections allowed us to distinguish 11 different habitat types, whereas the digital thematic maps only differentiated between 6 habitat types (Table 1). Dominant habitat types were arable land, forest, and grasslands. The proportions of these habitat types were similar in the field inspections and the maps (Table 1a and $b$ ). For example, the mean percentage of semi-natural habitats in a radius of $750 \mathrm{~m}$ was $10.5 \pm 9.3 \%$ for field data and $12.8 \pm 9.7 \%$ for data from digital maps and varied between 1.4 $28.0 \%$ and $0.1-36.6 \%$, respectively.

Table 2. Correlations between percentage of semi-natural habitats (rows) and the diversity of habitat types ( $H^{\prime}$, columns) at different spatial scales.

\begin{tabular}{ccccccccc}
\hline \hline $\begin{array}{c}\text { Percentage of } \\
\text { semi-natural } \\
\text { habitats }\end{array}$ & \multicolumn{9}{c}{ Scale for $H$} \\
\cline { 2 - 9 } at scale & $250 \mathrm{~m}$ & $500 \mathrm{~m}$ & $750 \mathrm{~m}$ & $1000 \mathrm{~m}$ & $1500 \mathrm{~m}$ & $2000 \mathrm{~m}$ & $2500 \mathrm{~m}$ & $3000 \mathrm{~m}$ \\
\hline $250 \mathrm{~m}$ & $0.870^{* * *}$ & $0.783^{* *}$ & $0.727^{* *}$ & $0.535^{*}$ & 0.474 & 0.348 & 0.310 & 0.325 \\
$500 \mathrm{~m}$ & $0.758^{* *}$ & $0.753^{* *}$ & $0.743^{* *}$ & $0.565^{*}$ & 0.479 & 0.409 & 0.396 & 0.479 \\
$750 \mathrm{~m}$ & $0.726^{* *}$ & $0.677^{* *}$ & $0.723^{* *}$ & $0.569^{*}$ & $0.527^{*}$ & 0.407 & 0.449 & 0.448 \\
$1000 \mathrm{~m}$ & $0.783^{* *}$ & $0.718^{* *}$ & $0.741^{* *}$ & $0.595^{*}$ & $0.558^{*}$ & 0.419 & $0.526^{*}$ & 0.451 \\
$1500 \mathrm{~m}$ & $0.745^{*}$ & $0.630^{*}$ & $0.644^{* *}$ & 0.494 & 0.438 & 0.346 & $0.559^{*}$ & 0.477 \\
$2000 \mathrm{~m}$ & $0.653^{* *}$ & $0.528^{*}$ & $0.520^{*}$ & 0.389 & 0.385 & 0.44 & $0.636^{*}$ & $0.556^{*}$ \\
$2500 \mathrm{~m}$ & $0.578^{*}$ & 0.436 & 0.445 & 0.352 & 0.410 & 0.471 & $0.608^{*}$ & $0.539^{*}$ \\
$3000 \mathrm{~m}$ & $0.548^{*}$ & 0.378 & 0.398 & 0.329 & 0.364 & 0.415 & $0.550^{*}$ & 0.510 \\
\hline$P<0.05 ; * *$
\end{tabular}

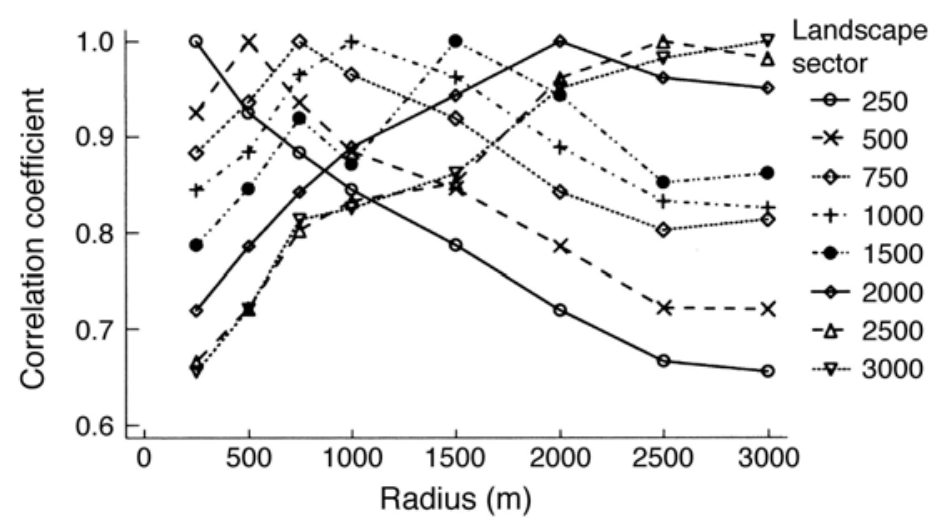

Figure 2. Correlation coefficients between the proportion of semi-natural habitats at different spatial scales. Proportions of semi-natural habitats are extracted from digital thematic maps (see Material and methods). 
The proportion of semi-natural habitats and the diversity of habitat types were significantly correlated at most spatial scales (Table 2). Due to this close intercorrelation, we focused our analyses on the proportion of semi-natural habitats. Furthermore, the proportion of seminatural habitats of landscape sectors of different size were only closely correlated when radii of landscape sectors were similar (Fig. 2).

\section{Flower-visiting insects}

A total of 865 wild bee individuals was observed in the field, and 475 individuals were caught for species identification. Altogether, we found 36 bee species from nine genera. The most species-rich genera were Lasioglossum (10 species), and Bombus ( 8 species) followed by Halictus (4), Megachile (4), Hylaeus (3), Chelostoma (2), Andrena (2), Psithyrus (2), and Melitta (1). Additionally, 467 honey bees (Apis mellifera) were observed. The mean number of observed wild bee species was $11 \pm 3.9$ per landscape sector, and the mean number of observed individuals per 15 min was $2.69 \pm 2.01$ for all wild bees (Table 3). Solitary wild bees were more abundant than honey bees and bumble bees. These three pollinator guilds varied considerably in species richness and/or abundance between the 15 study sites (Table $3)$. Species richness and abundance of flower-visiting wild bees were closely correlated $\left(r^{2}=\right.$ $0.733, n=15, P<0.001)$.

Table 3. Species richness and species abundance for all wild bees, solitary wild bees, bumble bees, and honey bees.

\begin{tabular}{ccccc}
\hline \hline Factor & Species group & Mean \pm 1SD & Minimum & Maximum \\
\hline Species richness & all wild bees & $11 \pm 3.85$ & 6 & 17 \\
& solidary wild bees & $7.73 \pm 3.83$ & 3 & 15 \\
bumble bees & $3.27 \pm 1.5$ & 1 & 6 \\
Abundance (no. & all wild bees & $2.69 \pm 2.01$ & 0.81 & 7.59 \\
individuals all & solidary wild bees & $1.84 \pm 2.03$ & 0.2 & 6.47 \\
wild bees per 15 & bumble bees & $0.85 \pm 0.53$ & 0.23 & 2.14 \\
min) & Honey bees & $1.24 \pm 0.89$ & 0.1 & 3.37 \\
\hline Note: Means $\pm 1 \mathrm{SD}$, minimum, and maximum are given for 15 study sites.
\end{tabular}

\section{Scale-dependent effects of landscape context}

The focus of this study was on the effects of landscape context on pollinators at different spatial scales. For small scales up to $750 \mathrm{~m}$ we could rely on our own field data. Both species richness and abundance of wild bees significantly increased with the proportion of seminatural habitats at all three scales (Table 4). The strongest correlation between species 
richness and abundance of all wild bees and the proportion of semi-natural habitats was found for the $750 \mathrm{~m}$ radius (Fig. 3a and b). Similarly, the number of species and the abundance of solitary wild bees were closely correlated with the proportion of semi-natural habitats, whereas bumble bees and honey bees did not show a relationship with landscape context at scales up to $750 \mathrm{~m}$ (Table 4). Total pollinator abundance (including all wild bees and honey bees) declined with decreasing proportion of semi-natural habitats $(y=0.47+0.22 \arcsin \sqrt{ } x$; $\left.r^{2}=0.722, F=33.83, n=15, P=0.001\right)$, i.e., the general pattern was determined by the distribution of solitary wild bees. The mean body size of solitary flower-visiting bees showed a tendency to increase in landscapes with lower proportions of semi-natural habitats $\left(r^{2}=\right.$ $0.238, n=15, P=0.065)$.
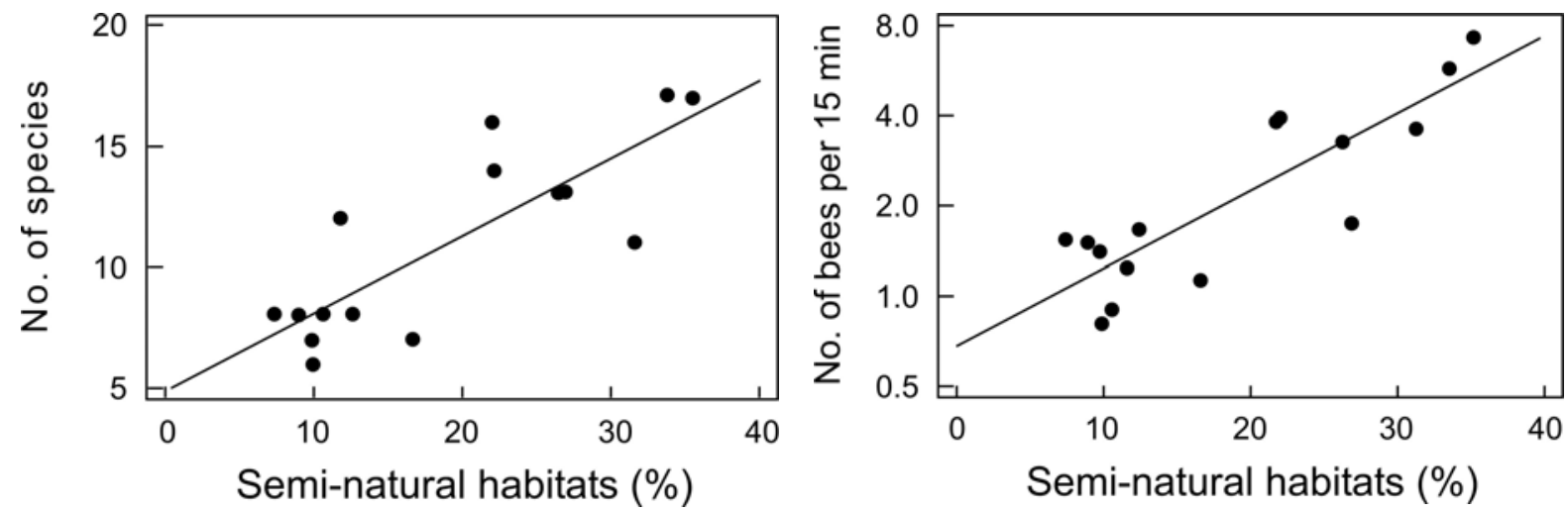

Figure 3a: Relationship between the number of species Figure 3b: Relationship between the number richness of flower-visiting wild bees on five (abundance) of flower-visiting bees per 15 min and the experimentally exposed potted plant species and the proportion of semi-natural habitats in a radius of 750 proportion of semi-natural habitats (in a radius of $\mathrm{m}$ : $\ln (\mathrm{y})=-0.40+0.0748 \mathrm{x} \arcsin \sqrt{\mathrm{x}} ; \mathrm{r} 2=0.738, \mathrm{~F}=$ $750 \mathrm{~m}$ ) and the proportion of semi-natural habitats: $y=36.58, \mathrm{n}=15, \mathrm{P}<0.001$. Note the logarithmic scale for $4.865+0.396 \times \arcsin \sqrt{ } x ; r^{2}=0.673, F=26.75, n=15$, bee abundance. $P<0.001$.

In the next step, we analysed the effects of landscape structure at multiple spatial scales on pollinator distribution using data from digital thematic maps. For each of eight landscape sectors between 250 and 3000 m radius, we tested how species richness and abundance of all wild bees, solitary wild bees, bumble bees, and honey bees was related to landscape structure. For scales between 250 and $750 \mathrm{~m}$, the results were similar to those from the field inspections, indicating that the less detailed data from digital maps were similarly useful in predicting the distribution of bees (Table 5). Again, species richness and abundance of solitary wild bees were a positive function of the proportion of semi-natural habitats, whereas the bumble bees and honey bees did not show a significant correlation. However, the best correlations for the 
distribution of species richness or abundance of all wild bees or solitary wild bees was found in a radius of $250 \mathrm{~m}$ and explained $\sim 25 \%$ less of the variation than the detailed data from our field inspections (see Tables 4 and 5).

Table 4. Relationship between species richness and abundance of pollinator groups and the proportion of semi-natural habitats at three spatial scales.

\begin{tabular}{|c|c|c|c|c|c|c|}
\hline \multirow[b]{3}{*}{ Species group } & \multicolumn{6}{|c|}{ Scale } \\
\hline & \multicolumn{2}{|l|}{$250 \mathrm{~m}$} & \multicolumn{2}{|l|}{$500 \mathrm{~m}$} & \multicolumn{2}{|l|}{$750 \mathrm{~m}$} \\
\hline & Corr. Coef. & $p$ & Corr. Coef. & $p$ & Corr. Coef. & $p$ \\
\hline \multicolumn{7}{|c|}{ Species richness (no.) } \\
\hline All wild bees & 0.710 & 0.003 & 0.770 & $<0.001$ & 0.820 & $<0.001$ \\
\hline Solitary wild bees & 0.804 & $<0.001$ & 0.870 & $<0.001$ & 0.856 & $<0.001$ \\
\hline Bumble bees & -0.286 & ns & -0.286 & ns & -0.071 & ns \\
\hline \multicolumn{7}{|c|}{ Abundance (no. individuals per $15 \mathrm{~min}$ ) } \\
\hline All wild bees & 0.746 & 0.001 & 0.824 & $<0.001$ & 0.859 & $<0.001$ \\
\hline Solitary wild bees & 0.787 & $<0.001$ & 0.822 & $<0.001$ & 0.842 & $<0.001$ \\
\hline Bumble bees & -0.224 & ns & -0.094 & $\mathrm{~ns}$ & 0.040 & ns \\
\hline Honey bees & -0.017 & ns & -0.037 & ns & 0.086 & ns \\
\hline
\end{tabular}

A scatterplot of $r^{2}$ values for solitary wild bees, bumble bees, and honey bees with the proportion of semi-natural habitats over all landscape sectors indicated that each pollinator group depended on landscape structure at different spatial scales. The amount of variation in solitary wild bee abundance explained by the proportion of semi-natural habitats in the surrounding landscape decreased with increasing spatial scale (Fig. 4a and b). The dependence of bumble bees on landscape context was weak and not significant at any scale (Fig. 4c and d). In clear contrast, the significance of landscape context for the distribution of honey bees increased with the tested spatial scale (Fig. 4e). Interestingly, the abundance of flower-visiting honey bees increased with decreasing proportion of semi-natural habitats at the largest spatial scale (Fig. 4f). 
Table 5. Relationship between species richness and abundance of pollinator groups and the proportion of seminatural habitats at eight spatial scales.

\begin{tabular}{|c|c|c|c|c|c|c|c|c|}
\hline \multirow[b]{3}{*}{ Species group } & \multicolumn{8}{|c|}{ Scale } \\
\hline & \multicolumn{2}{|c|}{$250 \mathrm{~m}$} & \multicolumn{2}{|c|}{$500 \mathrm{~m}$} & \multicolumn{2}{|c|}{$750 \mathrm{~m}$} & \multicolumn{2}{|c|}{$1000 \mathrm{~m}$} \\
\hline & Corr.Coef. & $P$ & Corr.Coef. & $P$ & Corr.Coef. & $P$ & Corr.Coef. & $P$ \\
\hline Species richness (no.) & 0.696 & 0.004 & 0.6187 & 0.014 & 0.521 & 0.046 & 0.533 & 0.041 \\
\hline All wild bees & 0.686 & 0.005 & 0.620 & 0.014 & 0.552 & 0.033 & 0.582 & 0.023 \\
\hline Solitary wild bees & 0.048 & 0.864 & 0.010 & 0.972 & 0.083 & 0.767 & -0.142 & 0.614 \\
\hline \multicolumn{9}{|l|}{ Bumble bees } \\
\hline \multicolumn{9}{|c|}{ Abundance (no. individuals per 15min) } \\
\hline All wild bees & 0.779 & 0.001 & 0.729 & 0.002 & 0.715 & 0.003 & 0.755 & 0.001 \\
\hline Solitary wild bees & 0.621 & 0.014 & 0.601 & 0.018 & 0.502 & 0.056 & 0.538 & 0.038 \\
\hline Bumble bees & 0.361 & 0.186 & 0.368 & 0.177 & 0.407 & 0.132 & 0.403 & 0.137 \\
\hline \multirow[t]{3}{*}{ Honey bees } & 0.013 & 0.964 & -0.068 & 0.810 & -0.199 & 0.476 & -0.238 & 0.394 \\
\hline & \multicolumn{8}{|c|}{ Scale } \\
\hline & \multicolumn{2}{|c|}{$1500 \mathrm{~m}$} & \multicolumn{2}{|c|}{$2000 \mathrm{~m}$} & \multicolumn{2}{|c|}{$2500 \mathrm{~m}$} & \multicolumn{2}{|c|}{$3000 \mathrm{~m}$} \\
\hline Species group & Corr.Coef. & $P$ & Corr.Coef. & $P$ & Corr.Coef. & $P$ & Corr.Coef. & $P$ \\
\hline Species richness (no.) & 0.376 & 0.168 & 0.296 & 0.284 & 0.284 & 0.305 & 0.236 & 0.397 \\
\hline All wild bees & 0.448 & 0.094 & 0.357 & 0.188 & 0.337 & 0.220 & 0.283 & 0.307 \\
\hline Solitary wild bees & -0.218 & 0.436 & -0.192 & 0.493 & -0.159 & 0.571 & -0.142 & 0.614 \\
\hline Bumble bees & & & & & & & & \\
\hline Abundance (no. indivi & als per $15 \mathrm{~m}$ & & & & & & & \\
\hline All wild bees & 0.604 & 0.017 & 0.571 & 0.026 & 0.599 & 0.018 & 0.461 & 0.084 \\
\hline Solitary wild bees & 0.422 & 0.117 & 0.437 & 0.117 & 0.476 & 0.073 & 0.414 & 0.125 \\
\hline Bumble bees & 0.358 & 0.190 & 0.256 & 0.357 & 0.197 & 0.482 & 0.169 & 0.557 \\
\hline Honey bees & -0.273 & 0.324 & -0.322 & 0.241 & -0.375 & 0.169 & -0.408 & 0.131 \\
\hline
\end{tabular}

Notes: Correlation coefficients (Corr. Coef.) and significance levels are given for simple linear regressions. Proportions of semi-natural habitats are extracted from digital thematic maps (see Material and methods).

\section{DISCUSSION}

Our results show that landscape context significantly influences pollinator diversity and abundance. Furthermore, the three main pollinator groups, solitary wild bees, bumble bees, and honey bees responded to landscape context at different spatial scales.

We focused on one parameter to quantify landscape structure, the proportion of semi-natural habitats in a landscape. This parameter was correlated with other potential indicators of landscape structure such as the diversity of habitat types, mean habitat size, and habitat isolation for both the data from digital thematic maps and the field data (see Thies and Tscharntke 1999). Similarly, Gustafson (1998:150) argues that "knowing the proportion of a type of interest tells you almost as much as knowing many other measures of heterogeneity." 

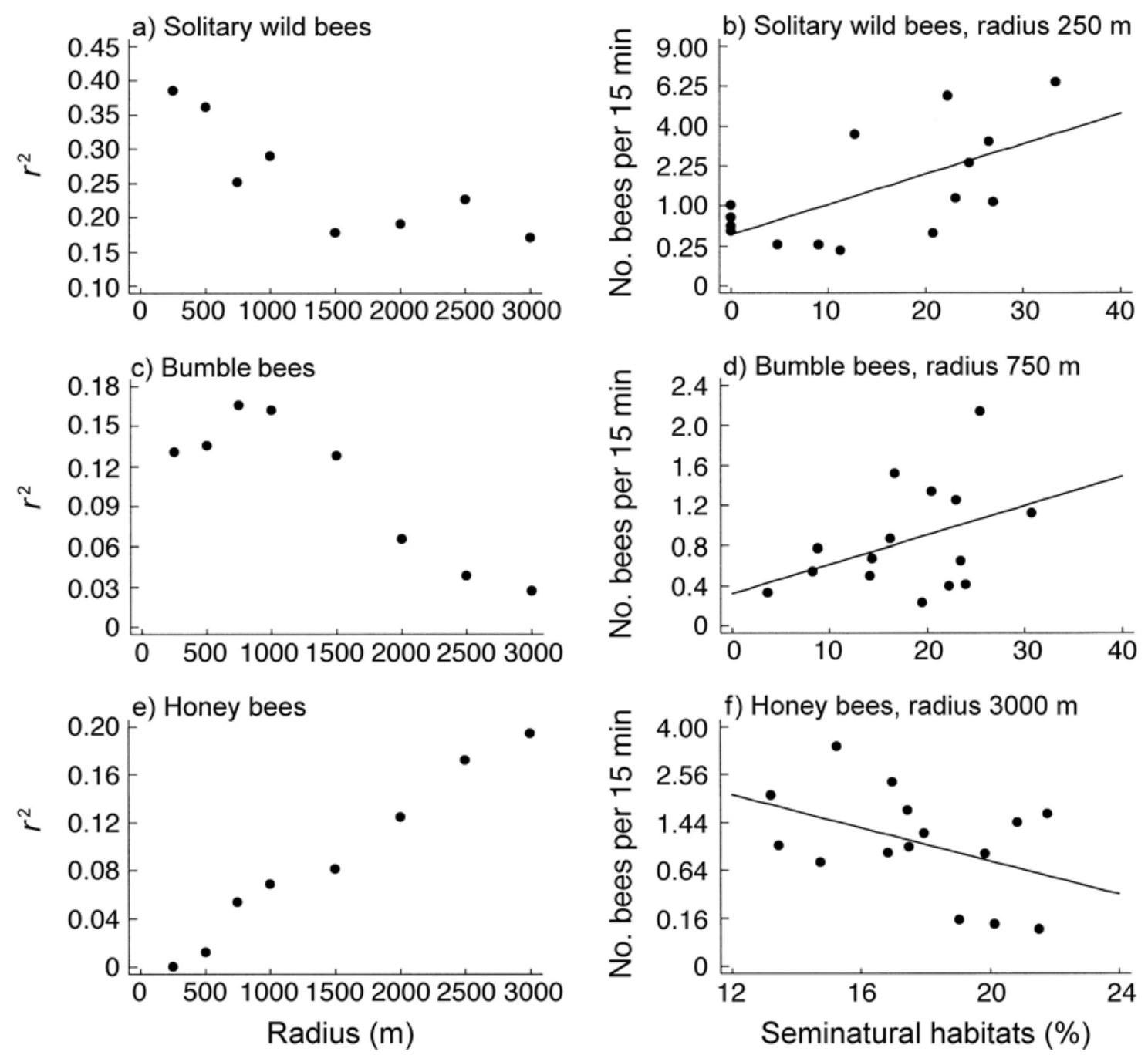

Figure 4. Scale-dependent effects of landscape structure on flower-visiting solitary wild bees, bumble bees, and honey bees. In panels (a, c, e), for eight landscape sectors of 250-3000 m radius, $r^{2}$ values for simple linear regressions between the proportion of semi-natural habitats and the number of flowervisiting bees per $15 \mathrm{~min}$ are presented. In panels $(\mathrm{b}, \mathrm{d}, \mathrm{f})$, the relationships between bee abundance per $15 \mathrm{~min}$ and the proportion of semi-natural habitats are presented. Simple linear regressions for the spatial scale with the highest $r^{2}$ value are shown. Solitary wild bees: $\sqrt{ } y=0.641+0.038 \mathrm{x} \arcsin \sqrt{ } x ; \mathrm{r}^{2}=$ $0.413, F=9.15, n=15, P=0.010$. Bumble bees: $r^{2}=0.162, F=2.51, n=15, P=0.137$. Honey bees: $\sqrt{ } y=2.27-0.069 \times \arcsin \sqrt{ } x ; r^{2}=0.194, F=3.13, n=15, P=0.100$. Note the square-root scale for bee abundance in panels (d) and (f). Proportions of semi-natural habitats are extracted from digital thematic maps (see Material and methods).

We conclude that for our study system it is better to use a simple and ecologically relevant factor instead of difficult-to-interpret indices that combine multiple components. However, not only the proportion of semi-natural habitats but also changes in habitat diversity and habitat isolation may have influenced the observed patterns. Depending on the proportion of suitable habitat, either the amount of habitat or the habitat isolation may be more important (Andre'n 1994). 
The overall diversity and density of flower-visiting bees linearly declined with decreasing proportion of semi-natural habitats. Thus, we did not find a critical threshold of habitat destruction beyond which diversity drastically drops as some models suggest (Kareiva and Wennergren 1995, With and Crist 1995, Andrén 1999, Keitt et al. 1997), although the proportion of semi-natural habitats was $<5 \%$ in seven landscapes due to intensive agricultural land use. Our empirical data suggest a much simpler relationship, as Kareiva and Wennergren (1995:302) formulate: "species are steadily lost in direct proportion to habitat destruction (without hidden thresholds...)" Nonetheless, our data show an alarming loss of pollinator diversity and abundance in structurally simple landscapes. In these landscapes, pollinator services mainly depend on some bumble bee species and honey bees.

Solitary wild bees, bumble bees, and honey bees revealed different degrees of dependence on landscape structure. This may have two reasons: First, solitary wild bees have specific habitat requirements and can be assumed to be more restricted to semi-natural habitats such as calcareous grasslands or orchard meadows than bumble bees and honey bees (Osborne et al. 1991, Banaszak 1992, O'Toole 1993). Second, foraging ranges of solitary wild bees are smaller than those of bumble bees and honey bees, although concrete data are still lacking in many cases (Eickwort and Ginsberg 1980, Visscher and Seeley 1982, Wesserling and Tscharntke 1995, Dramstad 1996, Osborne et al. 1999). The importance of foraging ranges is supported by the observed increase in mean body size of solitary wild bees in landscapes with lower proportion of suitable habitat and higher patch isolation, because larger species are assumed to have better flight capabilities and larger foraging distances (see Gathmann et al. 1994, van Nieuwstadt and Iraheta 1996, Steffan-Dewenter and Tscharntke 1999). Solitary wild bees and honey bees showed contrasting responses when we analysed different spatial scales. The distribution of solitary wild bees could be best explained by the percentage of semi-natural habitat at small spatial scales whereas honey bees responded to landscape structure only at large scales. This supports the view that species perceive the landscape structure at different spatial scales depending on their dispersal abilities or foraging ranges (Keitt et al. 1997, With et al. 1999). Interestingly, the densities of honey bees visiting the experimental patches of flowering plants increased when the proportion of semi-natural habitats decreased. The predictive power of the larger scales in our study fit well with the foraging range of honey bees of $2.5-3 \mathrm{~km}$ and indicates that a colony selects the most profitable flower patches in this range (Visscher and Seeley 1982, Steffan-Dewenter and Tscharntke 2000b). In landscapes dominated by crop fields, alternative food sources were presumably rare, and therefore, honey bees visited the experimental patches more intensively 
than in landscape sectors with a higher proportion of semi-natural habitats. The local distribution and density of foraging honey bees clearly depends also on the location of apiaries. We have not yet a complete database of apiaries in all studied landscapes, but beekeepers often use semi-natural habitats to place their colonies, possibly resulting in a positive correlation between the proportion of semi-natural habitats and the density of honey bee colonies (Steffan-Dewenter and Tscharntke 2000b). Therefore, from the distribution of honey bee colonies we would expect the opposite pattern to the one we found, i.e., higher densities of flower-visiting honey bees in structurally rich landscapes. To summarize, the spatial pattern of bee foraging may be affected by: the spatial arrangement of additional flower patches, which are predicted to be more abundant in structurally rich than poor landscapes; the spatial scale at which the flower visitor perceives variation in flower abundance depending on species-specific foraging ranges; and by the distribution of nesting sites, which should be more important for solitary wild bees than for social bees.

Our results may have implications for both competitive interactions between bees and mutualistic interactions between plants and pollinators. The higher foraging density of honey bees in landscapes with lower proportions of semi-natural habitat suggest a higher foraging pressure by honey bees on isolated habitat fragments in such landscapes. Thus, the potential of mosaic landscapes to lower competitive pressure (Hanski 1995) may be lost in very simple landscapes with few alternative food resources. Although landscape structure has been suggested to influences competition between honey bees and wild bees under certain conditions (e.g., Steffan-Dewenter and Tscharntke 2000b), we are not aware of any empirical studies to date showing contrasting foraging patterns related to landscape context at different spatial scales.

Our data suggest that small plant patches are well connected in structurally rich landscapes, whereas connectivity in landscapes with low proportions of semi-natural habitats is maintained only by a few social species (bumble bees and honey bees) with large foraging ranges. The decline of these remaining species would have severe effects on allogamous plant species (Corbet 1997). Furthermore, the loss of pollinator diversity and the dominance of bumble bees and honey bees in landscapes with low proportions of semi-natural habitats may favor plant species that require only generalist pollinators with the possible long-term loss of more specialized plant species relying on more specialist solitary bees (Rathcke and Jules 1993, Kearns et al. 1998). However, lower proportions of seeds damaged by seed predators in landscapes with few semi-natural habitats may counterbalance the negative effects of pollinator limitation on the number of remaining seeds (Steffan-Dewenter et al. 2001). 
Most published studies on the effects of landscape context, dealing almost always with vertebrates not insects, analysed species occurrence in native habitat fragments and asked for additional matrix effects (e.g., Aberg et al. 1995, Stouffer and Bierregaard 1995, Gascon et al. 1999, Norton et al. 2000). In these studies, community changes depend on fragment size or quality and matrix composition. In contrast, our experimental patches were placed in the nonhabitat matrix and thereby allow for an assessment of landscape effects independent from local habitat effects. By exposing potted plants of identical origin, growing in one soil type with the same nutrient and water availability, we were able to minimize possible confounding factors. For example, landscape structure correlated with nutrient richness of soils, but not with insecticide application (I. Roschewitz, unpublished data). Diversity of butterflies in a Swedish agricultural landscape depended on landscape heterogeneity but no differences between organic and conventional farms were found (Weibull et al. 2000). In a recent study on the biodiversity of moths in a fragmented agricultural landscape in Costa Rica, Ricketts et al. (2001) mapped moths in agricultural habitats and quantified, at different radii in the surrounding landscape, the cover of the forest habitat. Correlations between species richness of moths and forest cover were low for small neighbourhood scales, but dramatically increased when neighbourhood scales of 1.0 and $1.4 \mathrm{~km}$ were used, indicating that landscape context at larger spatial scales was more important than at smaller scales.

We conclude (1) that landscape destruction affects solitary wild bees more than social bees, which possibly leads to changes in mutualistic and competitive interactions and (2) that only analyses of multiple spatial scales may detect the importance of landscape context for pollinator communities.

\section{ACKNOLEDGEMENTS}

We greatly thank Eric Gustafson, Simon Potts, Thomas J. Stohlgren, Catrin Westphal, and an anonymous reviewer for helpful comments on the manuscript.

\section{REFERENCES}

Aberg, J., G. Jansson, J. E. Swenson, and P. Angelstam. (1995): The effect of matrix on the occurrence of hazel grouse (Bonasa bonasia) in isolated habitat fragments. Oecologia 103:265-269. 
Aizen, M. A., and P. Feinsinger. (1994): Forest fragmentation, pollination, and plant reproduction in a chaco dry forest, Argentina. Ecology 75:330-351.

Allen-Wardell, G., et al. (1998): The potential consequences of pollinator declines on the conservation of biodiversity and stability of food crop fields. Conservation Biology 12: $1-11$.

Andre'n, H. (1994): Effects of habitat fragmentation on birds and mammals in landscapes with different proportions of suitable habitat. Oikos 71:355-366.

Andrén, H. (1999): Habitat fragmentation, the random sample hypothesis and critical thresholds. Oikos 84:306-308.

Banaszak, J. (1992): Strategy for conservation of wild bees in an agricultural landscape. Agriculture, Ecosystems and Environment 40:179-192.

Böhning-Gaese, K. (1997): Determinants of avian species richness at different spatial scales. Journal of Biogeography 24:49-60.

Cain, D. H., K. Riiters, and K. Orvis. (1997): A multi-scale analysis of landscape statistics. Landscape Ecology 12: 199-212.

Connor, E. F., A. C. Courtney, and J. M. Yoder. (2000): In-dividuals-area relationships: the relationship between animal population density and area. Ecology 81:734-748.

Corbet, S. (1997): Role of pollinators in species preservation, conservation, ecosystem stability and genetic diversity. Acta Horticulturae 437:219-230.

Cunningham, S. A. (2000): Depressed pollination in habitat fragments causes low fruit set. Proceedings of the Royal Society of London Series B 267:1149-1152.

Debinski, D. M., and R. D. Holt. (2000): A survey and overview of habitat fragmentation experiments. Conservation Biology 14:342-355.

Dramstad, W. E. (1996): Do bumblebees (Hymenoptera: Apidae) really forage close to their nests? Journal of Insect Behavior 9:163-182.

Eickwort, G. C., and H. S. Ginsberg. (1980): Foraging and mating behaviour. In Apoidea. Annual Review of Entomology 25:421-446.

Gascon, C., T. E. Lovejoy, R. O. Bierregaard, J. R. Malcom, P. C. Stouffer, H. L. Vasconcelos, W. F. Laurance, B. Zimmermann, M. Tocher, and S. Borges. (1999): Matrix habitat and species richness in tropical forest remnants. Biological Conservation 91: $223-229$.

Gathmann, A., H.-J. Greiler, and T. Tscharntke. (1994): Trap-nesting bees and wasps colonizing set-aside fields: succession and body size, management by cutting and sowing. Oecologia 98:8-14. 
Gilbert, F., A. Gonzales, and I. Evans-Freke. (1998): Corridors maintain species richness in the fragmented landscapes of a microecosystem. Proceedings of the Royal Society of London B 265:577-582.

Gonzales, A., J. H. Lawton, F. S. Gilbert, T. M. Blackburn, and I. Evans-Freke. (1998): Metapopulation dynamics, abundance, and distribution in a microecosystem. Science 281: 2045-2047.

Gustafson, E. J. (1998): Quantifying landscape spatial pattern: what is the state of the art? Ecosystems 1:143-156.

Hanski, I. (1995): Effects of landscape pattern on competitive interactions. Pages 203-224 in L. Hansson, L. Fahrig, and G. Merriam, editors. Mosaic landscapes and ecological processes. Chapman and Hall, London, UK. Hanski, I. 1998. Metapopulation dynamics. Nature 396:41-49.

Harrison, S., and E. Bruna. (1999): Habitat fragmentation and large-scale conservation: what do we know for sure? Ecography 22:225-232.

Holt, R. D., J. H. Lawton, G. A. Polis, and N. D. Martinez. (1999): Trophic rank and the species-area relationship. Ecology 80:1495-1504.

Jennersten, O. (1988): Pollination in Dianthus deltoides (Caryophyllaceae): effects of habitat fragmentation on visitation and seed set. Conservation Biology 2:359-366.

Kareiva, P. (1990): Population dynamics in spatially complex environments: theory and data. Philosophical Transactions of the Royal Society of London Series B, Biological Sciences 330:175-190.

Kareiva, P., and U. Wennergren. (1995): Connecting landscape patterns to ecosystem and population processes. Nature 373:299-302.

Kearns, C. A., D. W. Inouye, and N. M. Waser. (1998): Endangered mutualisms: the conservation of plant-pollinator interactions. Annual Review of Ecology and Systematics 29:83-112.

Keitt, T. H., D. L. Urban, and B. T. Milne. (1997): Detecting critical scales in fragmented landscapes. Conservation Ecology 1:1-17.[Online, URL: [http://www.consecol.org/ vol1/iss1/art4].]

Klemm, M. (1996): Man-made bee habitats in the anthropogenous landscape of central Europe - substitutes for threatened or destroyed riverine habitats? Pages 17-34 in A. Matheson, S. L. Buchmann, C. O’Toole, P. Westrich, and I. H. Williams, editors. The conservation of bees. Academic Press, London, UK. 
Krebs, C. J. (1989): Ecological methodology. Harper Collins, New York, New York, USA. Küster, H. 1999. Geschichte der Landschaft in Mitteleuropa. Beck, München, Germany.

Menalled, F. D., P. C. Marino, S. H. Gage, and D. A. Landis. (1999): Does agricultural landscape structure affect parasitism and parasitoid diversity? Ecological Applications 9: 634-641.

Metzger, J. P. (2000): Tree functional group richness and landscape structure in a Brazilian tropical fragmented landscape. Ecological Applications 10:1147-1161.

Norton, M. R., S. J. Hannon, and F. K. A. Schmiegelow. (2000): Fragments are not islands: patch vs. landscape perspectives on songbird presence and abundance in a harvested boreal forest. Ecography 23:209-223.

Osborne, J. L., S. J. Clark, R. J. Morris, I. H. Williams, J. R. Riley, A. D. Smith, D. R. Reynolds, and A. S. Edwards. (1999): A landscape-scale study of bumble bee foraging range and constancy, using harmonic radar. Journal of Applied Ecology 36:519-533.

Osborne, J. L., I. H. Williams, and S. A. Corbet. (1991): Bees, pollination and habitat change in the European Community. Bee World 72:99-116.

O'Toole, C. (1993): Diversity of native bees and agroecosystems. Pages 169-196 in J. LaSalle and I. D. Gauld, editors. Hymenoptera and biodiversity. CAB International, Wallingford, UK.

Rathcke, B. J., and E. S. Jules. (1993): Habitat fragmentation and plant-pollinator interactions. Current Science 65:273-277.

Ricketts, T. H. (2001): The matrix matters: effective isolation in fragmented landscapes. American Naturalist 158:87-99.

Ricketts, T. H., G. C. Daily, P. R. Ehrlich, and J. P. Fay. (2001): Countryside biogeography of moths in a fragmented landscape: biodiversity in native and agricultural habitats. Conservation Biology 15:378-388.

Roland, J., and P. D. Taylor. (1997): Insect parasitoid species respond to forest structure at different spatial scales. Nature 386:710-713.

Saunders, D. A., R. J. Hobbs, and C. R. Margules. (1991): Biological consequences of ecosystem fragmentation: a review. Conservation Biology 5:18-32.

Sokal, R. R., and F. Rohlf. (1995): Biometry. Freeman, New York, New York, USA.

Statgraphics. 1995. Statgraphics plus for Windows, version 2.1. Manugistics, Rockville, Maryland, USA. 
Steffan-Dewenter, I., U. Münzenberg, and T. Tscharntke. (2001): Pollination, seed set and seed predation on a landscape scale. Proceedings of the Royal Society of London Series B 268:1685-1690.

Steffan-Dewenter, I., and T. Tscharntke. (1999): Effects of habitat isolation on pollinator communities and seed set. Oecologia 121:432-440.

Steffan-Dewenter, I., and T. Tscharntke. (2000a): Butterfly community structure in fragmented habitats. Ecology Letters 3:449-456.

Steffan-Dewenter, I., and T. Tscharntke. (2000b): Resource overlap and possible competition between honey bees and wild bees in central Europe. Oecologia 122:288-296.

Stouffer, P. C., and R. O. Bierregaard. (1995): Effects of forest fragmentation on understory hummingbirds in Amazonian Brazil. Conservation Biology 9:1085-1094.

Thies, C., and T. Tscharntke. (1999): Landscape structure and biological control in agroecosystems. Science 285:893-895.

Tischendorf, L., and L. Fahrig. (2000): On the usage and measurement of landscape connectivity. Oikos 90:7-19.

Tscharntke, T., I. Steffan-Dewenter, A. Kruess, and C. Thies. (2002): Contribution of small habitat fragments to conservation of insect communities of grassland-cropland landscapes. Ecological Applications 12:354-363.

Turner, M. G., and R. H. Gardner. (1991): Quantitative methods in landscape ecology. Springer, New York, New York, USA.

Turner, M. G., R. H. Gardner, and R. V. O’Neill. (2001): Landscape ecology in theory and practice. Springer, New York, New York, USA.

van Nieuwstadt, M. G. L., and C. E. R. Iraheta. (1996): Relation between size and foraging range in stingless bees (Apidae, Meliponinae). Apidologie 27:219-228.

Visscher, K. P., and T. D. Seeley. (1982): Foraging strategy of honeybee colonies in a temperate deciduous forest. Ecology 63:1790-1801.

von Drachenfels, O. (1996): Rote Liste der gefährdeten Biotoptypen in Niedersachsen Bestandsentwicklung und Gefährdungsursachen der Biotop- und Ökosystemtypen sowie ihrer Komplexe. Naturschutz und Landschaftspflege in Niedersachsen 34. Niedersächsisches Landesamt für Ökologie, Hannover, Germany.

Weibull, A.-C., J. Bengtsson, and E. Nohlgren. (2000): Diversity of butterflies in the agricultural landscape: the role of farming system and landscape heterogeneity. Ecography 23:743-750. 
Wesserling, J., and T. Tscharntke. (1995): Homing distances of bees and wasps and the fragmentation of habitats. Mitteilungen der Deutschen Gesellschaft für Allgemeine und Angewandte Entomologie 10:323-326.

Westrich, P. (1996): Habitat requirements of central European bees and the problems of partial habitats. Pages 1-16 in A. Matheson, S. L. Buchmann, C. O’Toole, P. Westrich, and I. H. Williams, editors. The conservation of bees. Academic Press, London, UK.

Wiegand, T., K. A. Moloney, J. Naves, and F. Knauer. (1999): Finding the missing link between landscape structure and population dynamics: a spatially explicit perspective. American Naturalist 154:605-627.

With, K. A., S. J. Cadaret, and C. Davis. (1999): Movement responses to patch structure in experimental fractal landscapes. Ecology 80:1340-1353.

With, K. A., and T.O. Crist. (1995): Critical thresholds in species' responses to landscape structure. Ecology 76: 2446-2459. 


\title{
Possible effects of landscape context and pollinator densities on yield of oilseed rape
}

\begin{abstract}
It has been suggested that biodiversity in agroecosystems is influenced by landscape context , and enhanced diversity and density of bees may have positive effects on the yield of oilseed rape (Brassica napus L.). In a two-years study we analysed species richness and density of flower-visitors on rapecrop fields in 17 landscapes in 18 circular sectors differing in structural complexity. In the centre of each circular landscape sector (radius 3000m) a rapecrop field was chosen as a study field. Landscape context was quantified as the percentage of seminatural habitats, the percentage of rapecrop fields and MPAR (Mean Perimeter-Area-Ratio) at twelve nested spatial scales (radius of landscape sectors, 250-3000m). Surprisingly, landscape analyses showed no relationship between species richness and abundance of pollinators and landscape context. In addition, we expected higher bee density to increase pollination rates and yields of oilseed rape. In fact, we found that higher abundance of managed honey bees significantly increased seed set per flower, but no effects of abundance of flower-visiting wild bees on yield of oilseed rape. Bee visitation had no effect on real yield $\left(\mathrm{g} / \mathrm{m}^{2}\right)$, probably as a result of the high compensatory-growth ability of oilseed rape (Williams 1979) and variation in cultivation methods or local soil conditions. In contrast, rape yield was positively related to higher percentage of rape crop fields in the landscape, possibly due to enhanced wind pollination. In conclusion, fruit set and yield of oilseed rape was highly variable and only partly related to the measured parameters, so more complex multi-factor analysis, considering field management, soil quality, pollination and herbivory simultaneously, are needed.
\end{abstract}

\section{Keywords}

Pollination, landscape structure, spatial scales, bees, ecosystem services, crop yields, Brassica napus 


\section{INTRODUCTION}

During the last decades, widespread destruction and fragmentation of natural habitats has become a major issue concerning agricultural landscapes. Human interventions often reduce biological diversity and change community structure (Jedicke 1994, Bierregard et al. 1992, Antrop 2000, Goverde et al. 2002, Tscharntke et al. 2002). Effects of habitat fragmentation and landscape context on a variety of species and ecosystems are a current topic of ecological research (Saunders et al. 1991, Kleyer et al. 1996, Hanski 1999, Harrison \& Bruna 1999). Landscape context and habitat fragmentation represent important parameters for examining landscapes for their ecological functionality (Kareiva \& Wennergren 1995, Gustafson 1998). Particularly, the intensification of agricultural land use and destruction of natural habitats cause not only the loss of species (Saunders et al. 1991, De la Pena et al 2003) but also important ecological functions such as pollination of plants or pest control by their natural antagonists (Rathcke \& Jules 1993, Steffan-Dewenter \& Tscharntke 1999, Thies \& Tscharntke 1999, Menalled et al. 1999). Thus, agricultural intensification may reduce the diversity and abundance of wild bees and, thereby, pollination services below the necessary threshold to produce marketable products (Williams 1996, Kremen et al. 2002).

Pollination is an important ecosystem function of great economic and ecological importance (Allen-Wardell et al. 1998, Kearns et al. 1998). The preservation of this nature service depends on a great diversity and density of pollinators, i.e. native wild bees but also managed honey-bees (Roubik 2002, Klein et al. 2003). The destruction of natural habitats has led to a decrease in the wild bee density at the landscape level (Westrich 1989, O'Toole 1993). Therefore, the landscape context influences the availability of pollinators (Steffan-Dewenter et al. 2002). In addition, the number of beekeepers and the number of managed honey bees have decreased during the last decades (Bienefeld 1996). Reasons are (1) a lower availability of food resources in agricultural landscapes and (2) the loss of managed honey bees through increasing appearance of bee diseases. Therefore, sufficient pollination services for crops are endangered (Corbet et al. 1991, Kremen et al. 2002, Klein et al. 2003).

In this two-year study we analysed the effects of landscape context and landscape complexity in 18 independent landscape units (1) on the abundance and species richness of flowervisiting insects and (2) the fruit set of oilseed rape (Brassica napus L.). Previous research results show that isolated plant populations have a reduced fruit set (Aizen \& Feinsinger 1994, Agren 1996, Steffan-Dewenter \& Tscharntke 1999, Cunningham 2000) and that structurally rich landscapes contain a higher abundance and diversity of wild bees (Steffan- 
Dewenter et al. 2002). With regard to harvest parameters several studies have shown that high densities of pollinators enhance crop yields (Roubik 2002, Kremen et al. 2002, SteffanDewenter 2003).

With regard to pest control, in structurally rich landscapes Thies \& Tscharntke (1999) showed a higher rate of parasitism of the rape pollen beetle (Meligethes aeneus). Thus, structurally complex landscapes should provide both better pest control and more efficient pollination services, so we expected that crop yields would be influenced by landscape structure. However, there are only a few studies that show a reduced fruit set in cultivated plant in structurally simple landscapes (Kremen et al. 2002, Klein et al. 2003).

Farm management can influence species composition and species richness of local flora and fauna. Thus, ecological farm management can increase species richness and also can cause a positive influence on pest control (Ostmann et al. 2001a, 2001b, Richard 2001, Weibull et al. 2003). Furthermore, some studies assume that farm management is related to landscape type, in that structurally rich landscapes contain more organic fields (Roschewitz et al. 2003; submitted).

Winter oilseed rape (Brassica napus L. ssp. oleifera (Metzg.), Brassicaceae) is the economic most important oilseed crop in temperate agricultural regions. In Germany in 2002 approximately 1.28 million hectare (11\% of the total agricultural area) were sown with oilseed rape (Statistisches Bundesamt 2002). Oilseed rape is a predominantly self-pollinated crop with about one third out-crossing (Becker et al. 1992). Pollen transport by insects or wind is necessary (Williams 1978, Eisikowitch 1981, Free 1993, Westcott and Nelson 2001). In this study we expected (1) that fruit set and yields of oilseed rape are positively influenced by structurally rich landscapes and (2) that the abundance and diversity of pollinators will affect yields. 


\section{MATERIAL AND METHODS}

\section{Study region and study sites}

The study was conducted in 2001 and 2002 in the agricultural landscapes of southern Lower Saxony around the city of Göttingen (Germany) in a region of $45 \mathrm{~km}$ east-west and $35 \mathrm{~km}$ south-north. We selected 18 circular landscape sectors (radius $3000 \mathrm{~m}$ ) as study sites covering a gradient from structurally simple to structurally rich landscapes. The mean centre-to-centre distance between the 18 independent study sites were $6019 \mathrm{~m} \pm 620 \mathrm{~m}$ (range from $5160 \mathrm{~m}$ to $7075 \mathrm{~m})$. To measure the effect of landscape context on pollination and fruit set of oilseed rape, one rape field near the centre of each landscape sector was selected as study site. In 2001 we selected altogether 17 fields and 200218 fields, because crop rotation made selection impossible in one landscape. Insecticides were applied by farmers on all study fields.

\section{Quantifying landscape context}

For each of the 18 landscapes, different landscape metrics were calculated in twelve circular sectors (Ø 250m, Ø 500m, Ø 750m, Ø 1000m, Ø 1250m, Ø 1500m, Ø1750m, Ø 2000m, Ø $2250 \mathrm{~m}, \varnothing 2500 \mathrm{~m}, \varnothing 2750 \mathrm{~m}, \varnothing 3000 \mathrm{~m})$ using the Geographic Information System ARC $\backslash$ View 3.2 (ESRI Geoinformatik, Hannover, Germany). These circular sectors represented a nested set of landscape sectors at twelve spatial scales. To evaluate actual land use cover, we used official digital maps (Deutsche Grundkarte DGK 5, Landesvermessung und Geobasisinformation, Hannover, Germany) of the 18 landscapes with a area of $28 \mathrm{~km}^{2}$. Land use cover by 27 habitat types was subdivided in annual and perennial habitats. We differentiated between: (1) grain, (2) rapecrop fields, (3) sugar beets, (4) corn, (5) potatoes, (6) legumes ((6.1) sow beans, (6.2) peas), (7) other crops (7.1 - 7.5: alfalfa, Phacelia, mustard, tobacco, sunflowers), (8.1) sown fallows, (8.2) natural developed fallows, (9) grassland, (10) hedgerows, (11) running waters, (12) streets, (13) settlement, (14) waters, (15) forests, (16) urban park area, (17) garden land, (18) orchard meadows and (19) calcareous grasslands. For all habitat types we calculated the percent area for each radius of the landscape sector. In this study we summarized the annual habitat types to arable land; hedgerows, fallows, grasslands (grassland, orchard meadows and calcareous grasslands) and garden land were summarized to semi-natural habitats. Additionally, we calculated for each nested landscape sector the MPAR (Mean Perimeter-Area-ratio) as a measure of landscape complexity using the ARC $\backslash$ View extension PATCH Analyst 2.2. 


\section{Flower-visitor observation}

Observations of flower visitors were made in 2001 and 2002 (April - May) by visual counts along ten randomised 50m transect walks (5 near the margin, 5 in the centre; each 15 min; 150 min observation per field per year) through each of the 17 study sites in 2001 and 18 study sites in 2002. The number of species and individuals were recorded within a $4 \mathrm{~m}$ corridor in typical weather conditions, i.e. at least $16^{\circ} \mathrm{C}, 70 \%$ sunshine, and low wind velocity. The length of each transect was $50 \mathrm{~m}$. Bees were identified at genus level in the field and assigned to one of three pollinator groups, the honeybees (Apis mellifera), bumble bees (Bombus spp.) and solitary wild bees (mainly. Andrena, Osmia). Time of observation day was varied at a given study site for successive observations to obtain unbiased data. Altogether, 350 flower-visitor records (each based on 15 min observations) were made. The data were pooled, because there were no significant differences between the middle and the centre transect data.

\section{Yields of oilseed rape}

From each field 10 rape plants were collected shortly before regular harvest 21.-22. August in 2001; 07.-09. August in 2002), five from the field margin and five from the field centre in both study years. Mean number of pods (pods per plant), the number of seeds per plant, seed weight (g per plant), the plant weight (g of aboveground shoot) and the density of plants per $\mathrm{m}^{2}$ were determined. The total number of flowers per plant was calculated by counting the number of peduncles (flowers that did not develop into a pod) and adding it to the number of pods. Furthermore, the proportion of seeds per flower as a measure for pollination capability and the seed weight per $\mathrm{m}^{2}$ as yield parameter were calculated. The rapecrop study fields were located close to the landscape centre patch (distance rapecrop field to centre patch: $132 \mathrm{~m} \pm 78$ for 2001 and $90.7 \mathrm{~m} \pm 59.6 \mathrm{~m}$ for 2002).

\section{Statistical analysis}

The statistical analysis of the data were performed using Statgraphics plus 5.1 (Statgraphics 2001). All data were tested for normality and transformed where necessary. Arcsine-square root transformation were used to achieve normal distribution for percentages (Sokal and Rohlf 1995). We used paired t-test analysis to compare the results of each study year for the values 
of yield components of oilseed rape and the abundances of the three pollinator groups. Data analysis was done separately for each year because both years varied significantly in pollinator distribution.

Our statistical analyses were separated in two steps. In the first step, flower visitation data were correlated with yields and fruit set of oilseed rape to test for direct effects of bee pollination. In the second step we examined the effect of landscape context on fruit set and yields of oilseed rape at twelve spatial scales ranging from $\varnothing 250 \mathrm{~m}$ to $\varnothing 3000 \mathrm{~m}$ to test for landscape related patterns and to detect the spatial scale with the strongest effect. Pollinator abundance per study site was the mean number of observed flower-visiting bees over all transects, separated for 2001 and 2002. The effect of landscape context on pollinators was assessed using simple linear regressions. We analysed each of the twelve nested landscape sectors separately and tested the species richness and abundance of all wild bees, solitary wild bees, bumble bees and honey bees. Scatterplots were used to illustrate scale-dependent effects of $\mathrm{r}^{2}$ values for the correlation between landscape context and yield on oilseed rape (SteffanDewenter et al. 2002).

\section{RESULTS}

\section{Landscape context}

Landscape context was characterized by calculating the proportion of arable land (annual habitats), semi-natural habitats and proportion of rapecrop area. MPAR was calculated as a measure of landscape complexity at twelve spatial scales. At a small spatial scale, the dominant habitat type was cropland (Table 1). For example, the mean percentage of annual habitats in a radius of $250 \mathrm{~m}$ was $53.9 \pm 25.8$ in 2001 . The proportion of semi-natural habitats and the proportion of annual habitat types were negatively correlated at all spatial scales in 2001 and 2002 (linear regressions: $p<0.05$ ). Due to this close intercorrelation, we focused our analysis on the proportion of semi-natural habitats. No significant correlations existed between the three parameters proportions of the semi-natural habitats, proportion of rapecrop fields and MPAR at any spatial scale (250-3000m radius). 
Table 1: Habitat composition in the landscape sectors in Southern Lower Saxony, Germany.

\begin{tabular}{|c|c|c|c|}
\hline Habitat type & Area( \%) & Minimum (\%) & Maximum (\%) \\
\hline Arable land & $53.7 \pm 21.21$ & 13.25 & 83.23 \\
\hline $\begin{array}{l}\text { Rape crop area } \\
(2001)\end{array}$ & $7.61 \pm 4.15$ & 2.0 & 16.0 \\
\hline $\begin{array}{l}\text { Rape crop area } \\
(2002)\end{array}$ & $8.83 \pm 4.52$ & 2.0 & 19.0 \\
\hline Semi natural habitats & $19.06 \pm 10.4$ & 3.65 & 39.94 \\
\hline Hedgerows & $1.25 \pm 1.3$ & 0.18 & 5.7 \\
\hline Fallows & $3.04 \pm 2.15$ & 0.53 & 8.46 \\
\hline Grassland & $13.51 \pm 8.25$ & 1.89 & 30.76 \\
\hline Gardenland & $0.97 \pm 0.71$ & 0.02 & 2.46 \\
\hline Urban park area & $0.29 \pm 0.38$ & 0.03 & 1.83 \\
\hline Forests & $16.58 \pm 15.55$ & 0 & 54.0 \\
\hline Water areas & $0.53 \pm 0.63$ & 0 & 2.48 \\
\hline Settlement & $10.02 \pm 4.02$ & 4.69 & 23.61 \\
\hline
\end{tabular}

\section{Flower-visiting insects}

A total of 4863 flower-visiting insects was observed in the field in the years 2001 and 2002. All flower-visiting insects were separated into three pollinator guilds (honey bees, bumble bees and solitary wild bees) and a group a group of non-hymenopteran insects, mainly hover flies and butterflies. The results of the statistical analysis showed no differences in the abundance of flower-visiting insects between the years 2001 and 2002 (e.g. for bees: paired ttest: $\mathrm{N}=17 ; 2001: 48.6 \pm 50.1,2002: 42.8 \pm 31.7 ; \mathrm{t}=1.13 ; \mathrm{p}=0.277)$. The mean number of observed flower-visiting insects (observed within 150min) was $7.41 \pm 3.34$ individuals per 15 $\min$ in 2001 and $6.51 \pm 2.26$ in 2002 (Table 2). Within the group of flower-visiting bees, honey bees $(55.3 \%)$ were more abundant than solitary wild bees $(29.9 \%)$ and bumble bees (14.8\%). There were no significant relationships between the total abundance or the abundance of each of the three pollinator guilds and the calculated landscape metrics (percentage of natural habitats, percentage of rapecrop fields und MPAR; $p>0.1$ ).

\section{Fruit set on oilseed rape}

Altogether, we analysed 350 rape plants collected in 17 landscapes in 2001 and 18 landscapes in 2002. Table 3 gives the mean $\pm \mathrm{SD}$, minimum and maximum of pods, flowers, seed set, 
seed weight and plant weight. We could show significant differences between the years 2001 and 2001 with regard to the number of pods (paired t-test: $\mathrm{N}=17 ; \mathrm{t}=-6.73 ; \mathrm{p}<0.001$ ) and flowers (paired t-test: $\mathrm{N}=17 ; \mathrm{t}=6.08 ; \mathrm{p}<0.001$ ), but no differences in seed set and seed weight. Therefore, no differences could be found in yield between the two years $(p>0.1)$.

Table 2. Abundance for all flower-visiting insects, separated into honey bees, wild bees (solitary wild bees and bumble bees) and other flower-visiting insects in the years 2001 and 2002.

\begin{tabular}{lllccc}
\hline \hline Year & Factor & Species group & Mean \pm 1 SD & Minimum & Maximum \\
\hline \multirow{4}{*}{2001} & Honey bees & $2.43 \pm 2.48$ & 0.2 & 11.7 \\
& \multirow{3}{*}{ Abundance } & Wild bees & $1.91 \pm 1.36$ & 0.5 & 5.7 \\
& (no. individuals per & Solitary wild bees & $1.65 \pm 1.28$ & 0.2 & 4.9 \\
& 15 min) & Bumble bees & $0.56 \pm 0.34$ & 0.0 & 1.3 \\
& & Other insects & $3.07 \pm 1.66$ & 0.7 & 7.6 \\
\hline \multirow{4}{*}{2002} & Abundance & Honey bees & $2.11 \pm 2.85$ & 0.3 & 8.7 \\
& (no. individuals per & Wild bees & $1.75 \pm 0.96$ & 0.3 & 4.9 \\
& 15 min) & Solitary wild bees & $1.11 \pm 0.87$ & 0.2 & 3.6 \\
& & Bumble bees & $0.64 \pm 0.43$ & 0.0 & 1.6 \\
\hline
\end{tabular}

Note: Means \pm 1 SD, minimum and maximum are given for $\mathrm{n}=17$ study sites in 2001 and $\mathrm{n}=18$ study sites in 2002 (based on a 150 min observed period per study site)

Table 3. Yield components of oilseed rape in the years 2001 and 2002, respectively.

\begin{tabular}{clccc}
\hline \hline Year & \multicolumn{1}{c}{ Factor } & Mean \pm 1 SD & Minimum & Maximum \\
\hline \multirow{6}{*}{2001} & Pods & $197.23 \pm 40.38$ & 139.1 & 265.3 \\
& Flowers & $87.87 \pm 27.76$ & 57.8 & 140.6 \\
& Number of seeds & $3425.91 \pm 796.03$ & 2448.90 & 5340.80 \\
& Seed weight $(\mathrm{g})$ & $16.88 \pm 4.01$ & 11.62 & 26.98 \\
& Plant weight $(\mathrm{g})$ & $25.78 \pm 6.58$ & 17.56 & 39.68 \\
\hline & Yield $\left(\mathrm{g} / \mathrm{m}^{2}\right)$ & $518.74 \pm 133.29$ & 369.32 & 786.68 \\
\hline \multirow{6}{*}{2002} & Pods & $292.82 \pm 36.02$ & 211.0 & 362.4 \\
& Flowers & $43.41 \pm 13.54$ & 24.1 & 73.4 \\
& Number of seeds & $3199.77 \pm 782.61$ & 1979.60 & 4920.50 \\
& Seed weight $(\mathrm{g})$ & $17.66 \pm 2.55$ & 13.17 & 23.25 \\
& Plant weight $(\mathrm{g})$ & $29.20 \pm 2.95$ & 23.30 & 35.31 \\
\hline & Yield $\left(\mathrm{g} / \mathrm{m}^{2}\right)$ & $517.77 \pm 76.09$ & 406.31 & 639.19 \\
\hline
\end{tabular}

Note: Means $\pm 1 \mathrm{SD}$, minimum and maximum are given for $\mathrm{n}=17$ study sites in 2001 and $\mathrm{n}=18$ study sites in 2002 


\section{Fruit set and flower-visiting insects}

The effects of pollinator densities on yield components of oilseed rape were separately analysed for the two years (2001 and 2002). We only found positive significant relationships between honey bee density and seed set per flower and honey bee density and seed set per pod in the year 2002 (Fig. 1). With increasing honey bee abundance the number of seeds per flower and the number of seeds per pod increased significantly. However, there was no positive relation between the densities of the other pollinator groups with yield components (Tab.4).

Table 4: Relationship between abundance of pollinator groups and yield components of oilseed rape in 2001 and 2002.

\begin{tabular}{|c|c|c|c|c|c|c|}
\hline 2001 & & Yield & $\begin{array}{c}\text { Seed } \\
\text { set/Flower }\end{array}$ & Harvest_I & $\begin{array}{c}\text { Seed } \\
\text { set/pod }\end{array}$ & pods/Flower \\
\hline \multirow{3}{*}{ Honey bees } & $\mathbf{r}$ & -0.352 & 0.016 & -0.038 & -0.004 & -0.020 \\
\hline & $p$ & 0.166 & 0.953 & 0.884 & 0.989 & 0.938 \\
\hline & $\mathbf{r}$ & 0.279 & -0.027 & -0.235 & -0.215 & -0.401 \\
\hline Wild bees* & $p$ & 0.278 & 0.918 & 0.363 & 0.408 & 0.111 \\
\hline \multirow{2}{*}{$\begin{array}{l}\text { Solitary wild } \\
\text { bees }\end{array}$} & $\mathbf{r}$ & 0.174 & -0.048 & -0.191 & -0.173 & -0.488 \\
\hline & $p$ & 0.505 & 0.855 & 0.462 & 0.506 & $<0.05$ \\
\hline \multirow{2}{*}{ Bumble bees } & $\mathbf{r}$ & 0.233 & 0.326 & 0.037 & 0.092 & 0.109 \\
\hline & $p$ & 0.369 & 0.201 & 0.889 & 0.723 & 0.678 \\
\hline \multirow{2}{*}{ Bees (total) } & $\mathbf{r}$ & -0.069 & -0.038 & -0.153 & -0.149 & -0.281 \\
\hline & $p$ & 0.793 & 0.886 & 0.559 & 0.569 & 0.275 \\
\hline \multicolumn{2}{|l|}{2002} & Yield & $\begin{array}{c}\text { Seed } \\
\text { set/Flower }\end{array}$ & Harvest_I & $\begin{array}{c}\text { Seed } \\
\text { set/pod }\end{array}$ & pods/Flower \\
\hline \multirow[b]{2}{*}{ Honey bees } & $\mathbf{r}$ & 0.389 & 0.628 & 0.416 & 0.605 & -0.304 \\
\hline & $p$ & 0.111 & $<0.01$ & 0.086 & $<0.01$ & 0.221 \\
\hline \multirow{2}{*}{ Wild bees* } & $\mathbf{r}$ & -0.102 & -0.151 & -0.127 & -0.084 & -0.159 \\
\hline & $p$ & 0.687 & 0.550 & 0.614 & 0.740 & 0.525 \\
\hline \multirow{2}{*}{$\begin{array}{l}\text { Solitary wild } \\
\text { bees }\end{array}$} & $\mathbf{r}$ & -0.135 & -0.119 & -0.107 & -0.046 & -0.252 \\
\hline & $p$ & 0.592 & 0.639 & 0.671 & 0.858 & 0.312 \\
\hline \multirow{2}{*}{ Bumble bees } & $\mathbf{r}$ & 0.092 & -0.127 & -0.083 & -0.138 & 0.277 \\
\hline & $p$ & 0.716 & 0.616 & 0.743 & 0.586 & 0.263 \\
\hline \multirow{2}{*}{ Bees (total) } & $\mathbf{r}$ & 0.269 & 0.422 & 0.319 & 0.457 & -0.422 \\
\hline & $p$ & 0.282 & 0.081 & 0.198 & 0.057 & 0.081 \\
\hline
\end{tabular}

Note: $*$ Wild bees $=$ solitary wild bees and bumble bees; correlation coefficients $(\mathrm{r})$ and significance levels are given for simple linear regressions $(2001: \mathrm{n}=17 ; 2002: \mathrm{n}=18)$. Harvest_I $($ Harvest-Index $)=$ developed pods $/($ flower + developed pods $)$ 


\section{Fruit set and landscape context}

In 2001 we found no significant relationship between the yield of oilseed rape and the calculated MPAR, the proportion of semi-natural habitats and the proportion of rapecrop fields. In 2002, there were negative relationships between yield and MPAR and yield and the percentage of natural habitats. In this year, an increasing MPAR and increasing percentage of semi-natural habitats were significantly related to lower yields of oilseed rape (Fig.3.D + H). In contrast, a higher percentage of rapecrop area in the study landscapes was related to an increasing yield (Fig.3 L). A more detailed analysis showed a marginally significant positive relationship between seeds per flower and the percentage of rapecrop area (Fig. 2).

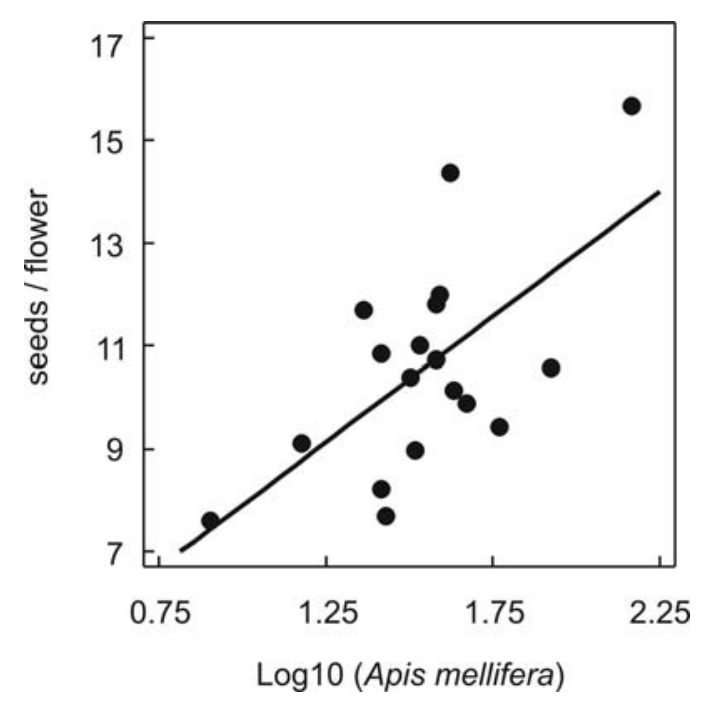

Figure 1: Relationship between the abundance of Apis mellifera and seeds per flower as yield component (linear correlation: $\underline{Y}=3.03+$ $\left.4.88 * \log 10(\mathrm{X}), \underline{\mathrm{F}}=10.42, \underline{\mathrm{P}}<0.01, \underline{\mathrm{R}^{2}}=39.44\right)$ in 2002.

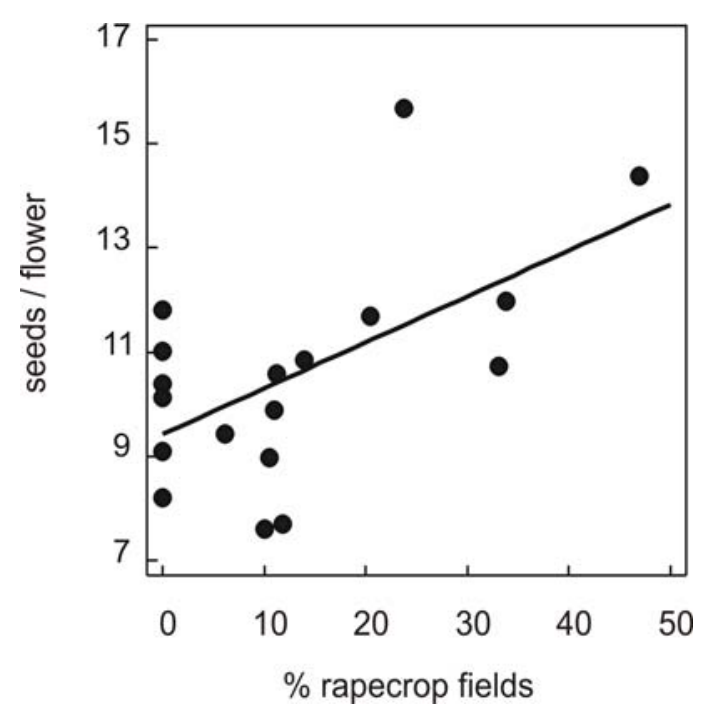

Figure 2: Relationship between the percentage of rapecrop area and seeds per flower as yield component (linear correlation: $\underline{\mathrm{Y}}=9.39+$ $0.07 * \operatorname{asin}(\operatorname{sqrt}(\mathrm{X} / 100)), \underline{\mathrm{F}}=4.46, \underline{\mathrm{P}}=0.051, \underline{\mathrm{R}^{2}}=$ $21.81)$ in 2002 at circle landscape sectors with $0.25 \mathrm{~km}$ radius. 


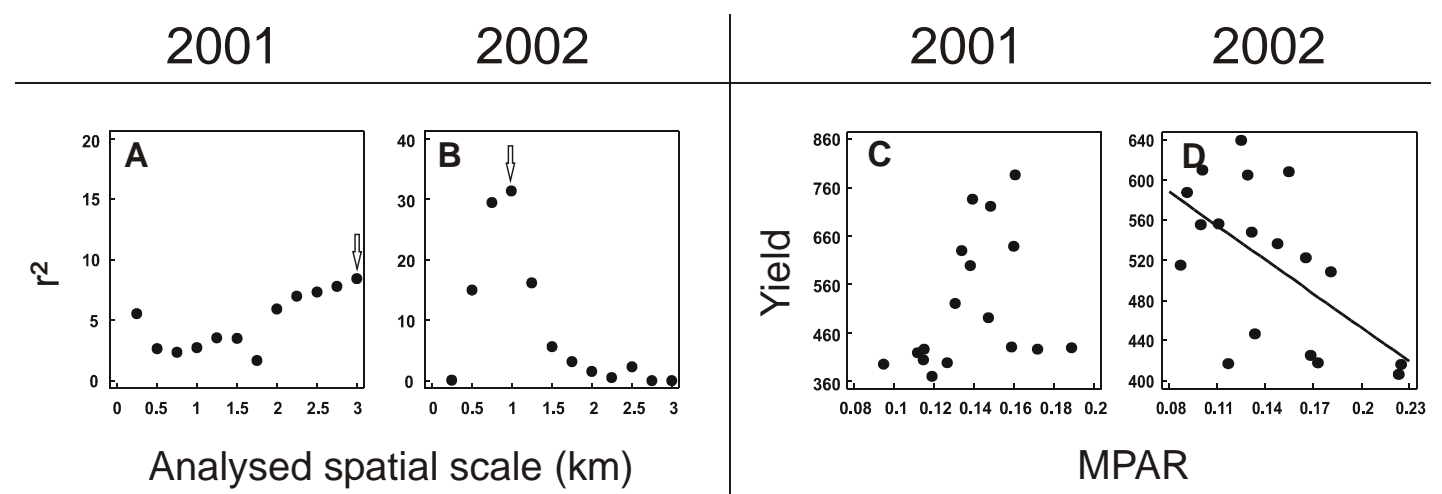

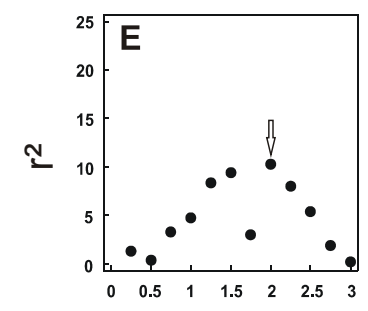

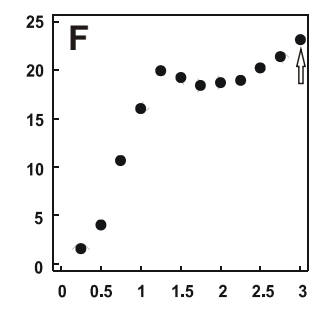

Analysed spatial scale $(\mathrm{km})$
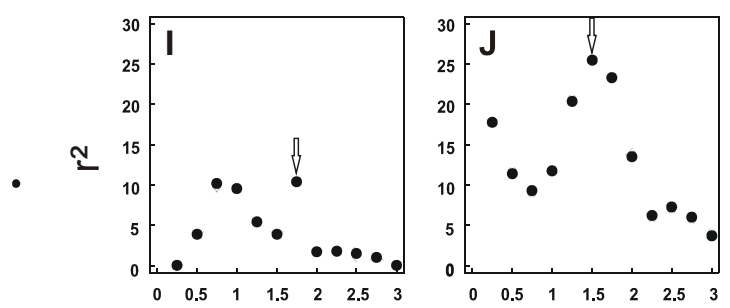

Analysed spatial scale $(\mathrm{km})$
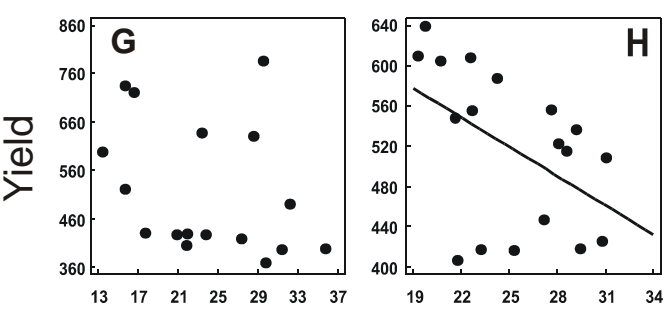

$\%$ semi-natural habitats
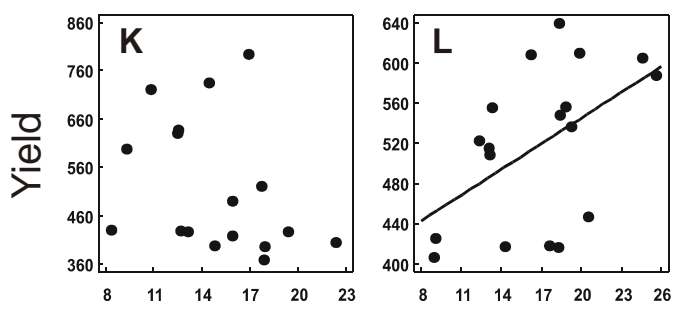

$\%$ rapecrop fields

Figure 3: Scale-dependent effects of the three landscape characteristics (MPAR $=$ Mean Perimeter-AreaRatio; percentage of semi-natural habitats; percentage of rapecrop field) on yield of oilseed rape over two years at different spatial scales (2001 and 2002; circle landscape sectors with $0.25 \mathrm{~km}$ to $3 \mathrm{~km}$ radius)

(A) $+(B) R^{2}$ values from simple regressions between yield of oilseed rape $\left(\mathrm{g} / \mathrm{m}^{2}\right)$ and MPAR at all spatial scales. $(E)+(F) R^{2}$ values from simple regressions between yield of oilseed rape $\left(\mathrm{g} / \mathrm{m}^{2}\right)$ and percentage of natural habitats (arcsine-square root transformed) at all spatial scales. (I)+(J) $\mathrm{R}^{2}$ values from simple regressions between yield of oilseed rape $\left(\mathrm{g} / \mathrm{m}^{2}\right)$ and percentage of rapecrop area (arcsine-square root transformed) at all spatial scales;

Linear regressions between yield of oilseed rape $\left(\mathrm{g} / \mathrm{m}^{2}\right)$ and $\operatorname{MPAR}\left(\mathbf{C}: \underline{\mathrm{P}}=0.193 ; \underline{\mathrm{R}^{2}}=11.03\right) ;(\mathbf{D}: \underline{\mathrm{Y}}=$ $\left.677.8-1123.3 * X ; \underline{\mathrm{F}}=8.59 ; \underline{\mathrm{P}}<0.01 ; \underline{\mathrm{R}^{2}}=34.94\right)$, percentage of natural habitats $\left(\mathbf{G}: \underline{\mathrm{P}}=0.210 ; \underline{\mathrm{R}^{2}}=\right.$ 10.24); $\left(\mathbf{H}: \underline{\mathrm{Y}}=761.8-9.7^{*} \operatorname{asin}(\operatorname{sqrt}(\mathrm{X} / 100)) ; \underline{\mathrm{F}}=4.82 ; \underline{\mathrm{P}}<0.05 ; \underline{\mathrm{R}^{2}}=23.67\right)$ and percentage of rapecrop area $\left(\mathbf{K}: \underline{\mathrm{P}}=0.207 ; \underline{\mathrm{R}^{2}}=10.41\right) ;\left(\mathbf{L}: \underline{\mathrm{Y}}=374.9+8.5^{*} \operatorname{asin}(\operatorname{sqrt}(\mathrm{X} / 100)) ; \underline{\mathrm{F}}=5.47 ; \underline{\mathrm{P}}<0.05 ; \underline{\mathrm{R}^{2}}\right.$ $=25.78)$. 


\section{DISCUSSION}

In our study we analysed yield components of oilseed rape (마assica napus) in dependence on pollinator densities and landscape context at different spatial scales focusing on three parameters to quantify the agricultural landscapes.

In contrast to expectations, our results showed no relationship between pollinator densities and landscape context and thus we could not prove positive influences of structurally rich landscapes or landscapes with a higher proportion of semi-natural habitats on pollinator density or pollinator diversities. Other studies in the same region show that bee abundance and species richness are significantly related to the proportion of semi-natural habitats (Steffan-Dewenter et al. 2001, 2002). Our results may have been caused by different effects: (A) Small patches of flowering plants as used by Steffan-Dewenter et al. (2001) may cause a concentration of pollinators. In contrast, rapecrop fields representing a mass abundant food resource can cause a dilution effect as shown by Thies et al. 2004 (submitted) for rape pod beetles. (B) In our field studies we showed a dominant role of flower-visiting honey bees on oilseed rape. Probably, wild bees preferred other food resources like the little rewarding wild plants. Structurally rich landscapes contain sufficient natural food resources to support a high diversity and abundance of wild bees (Banaszak 1992). Recent studies show that landscape diversity is positively correlated with species richness and species abundance (SteffanDewenter et al. 2002, Weibull 2003) and also support a higher pollination capacity. Accordingly, we expected that landscape characteristics would also affect the yield of oilseed rape by improving pollination and biological control (Steffan-Dewenter et al. 2001, Thies et al 2003). Studies which focused on isolated plant plots could confirm this relationship (SteffanDewenter \& Tscharntke 1999, Schulke \& Waser 2001).

We supposed that yield of oilseed rape $\left(\mathrm{g} / \mathrm{m}^{2}\right)$ is influenced by flower-visiting insects. This hypothesis could not be confirmed and the yield was similar in both years. However, we found that a higher abundance of managed honey-bees caused a higher seed set per flower. Hence, intensive insect pollination appeared to have positive effects on seed set. However, we could not prove any effect of native bee pollinators on yield of oilseed rape. Pollen beetles are known as potential pollinators of oilseed rape (Free \& Williams 1978), but densities are very low in this study region due to insecticide application.

Pollination of oilseed rape may take place in two different ways, first by flower-visiting insects and second by wind-pollination. Wind-pollination may be limited by a sufficient mass 
of pollen. Therefore, landscapes with high percentage of rapecrop fields should contain more pollen. A higher percentage of rapecrop area (within a landscape sector with $1.5 \mathrm{~km}$ radius) was significantly related to an increasing seed set. Limitation of wind pollination has been shown to affect seed set of male sterile oilseed rape, when potted plants were exposed at a distance to rapecrop fields (Grader et al, unpublished data). Further, higher percentage of rapecrop fields in a landscape may mean that different rape varieties are planted, thereby increasing a heterosis effect of cross-pollination by wind (Becker et al. 1992). A combined effect of enhanced wind pollination and a dilution effect with respect to herbivory (e.g. rape pollen beetle, see above) and pathogen infections may have been responsible for increased yields in landscapes dominated by rapecrop fields.

As far as we know, only a few other studies have analysed biotic interactions on a landscape level using independent landscape replicates (e.g. Thies \& Tscharntke 1999, SteffanDewenter 2001, Steffan-Dewenter et al. 2002), and none have examined yield components of oilseed rape in dependence on pollinator density and landscape context. Factors like flower and leaf herbivory may also be important and also depend on landscape context, but we did not analyse these interactions in our study. Furthermore, cultivating methods and local soil conditions are probably the most important factors for yield differences, but we not quantified in our study. In conclusion, there is a need for experimental studies that take into account the real complexity of driving forces of yield differences in oilseed rape, such as field management, soil quality, pollination, herbivory and pathogen infection to relate these patterns to landscape dynamics.

\section{ACKNOWLEDGEMENTS}

We greatly thank Carsten Thies, Jochen Krauss, Heiko Becker for advice and Barbara Ekbom for helpful comments on the manuscript and the farmers for providing the field sites. This work was supported by the Scholarship Program of the German Federal Environmental Foundation. 


\section{REFERENCES}

Deutsche Grundkarte DGK5; Landesvermessung und Geobasisinformation, Hannover, Germany 1991 - 1996.

ARC $\backslash$ View 3.2. Environmental Systems Research Institute. Inc. 1992-1999

Agren, J. (1996): Population size, pollinator limitation, and seed set in the self-incompatible herb Lythrum salicaria. Ecology 77, 1779-1790.

Aizen, M.A., \& Feinsinger, P. (1994): Forest fragmentation, pollination and plant reproduction in a chaco dry forest, Argentinia. Ecology 75, 330-351.

Allen-Wardell, G.,Bernhardt, P., Bitner, R., Burquez, A., Buchmann, S., Cane, J., Cox, P.A., Dalton, V., Feinsinger, P., Ingram, M., Inouye, D., Jones, C.E., Kennedy, K., Kevan, P., Koopowitz, H., Medellin, R., Medellin-Morales, S., Nabhan, G.P., Pavlik, B., Tepedino, V., Torchio, P., Walker, S. (1998): The potential consequences of pollinator declines on the conservation of biodiversity and stability of food crop fields. Conservation Biology 12, 1-11.

Antrop, M. (2000): Background concepts for integrated landscape analysis. Agriculture. Ecosystems and Environment 77, 17-28.

Banaszak, J. (1992): Strategy for conservation of wild bees in an agricultural landscape. Agriculture, Ecosystems and Environment 40 (1-4), 179-192.

Becker, H.C., Damgaard, C., Karlsson, B. (1992): Environmental variation for out-crossing rate in rapeseed (Brassica napus). Theor. Appl. Genet 84, 303-306

Bienefeld, K. (1996): Die Bedeutung der Bienenhaltung in Deutschland. Deutsches Bienenjournal 5, 14-18.

Bierregard, R., Lovejoy, T., Kapos, V., Dos Santos, A., Hutchings, R. (1992): The biological dynamics of tropical rainforest fragments. Bio-Science 42, 859-866.

Corbet, S.A.; Williams, I.H.; Osborne J.L. (1991): Bees and the Pollination of Crops and Wild Flowers in the European Community. Bee World 72, 47-59.

Cunningham, S. (2000): Depressed pollination in habitat fragments causes low fruit set. Proceedings of the Royal Society of London Series B 267, 1149-1152. 
De la Pena, N.M., Butet, A., Delettre, Y., Morant, P., Burelm, F. (2003): Landscape context and carabid beetles (Coleoptera : Carabidae) communities of hedgerows in western France. Agriculture, Ecosystems \& Environment 94 (1), 59-72.

Eisikowitch, D. (1981): Some aspects of pollination of oil-seed rape (Brassica napus L.). Journal of Agricultural Science (Camb) 96, 321-326.

Free, J.B. (1993): Insect pollination of crops. Academic Press, London, UK.

Free, J.B, Williams, I.H. (1978): Responses of the pollen beetle, Meligethes aeneus, and seed weevil, Ceuthorhynchus assimilis, to oil-seed rape, Brassica napus, and other plants. Journal of Applied Ecology 15 (3): 761-\&

Goverde M, Schweizer K, Baur B, Erhardt A (2002): Small-scale habitat fragmentation effects on pollinator behaviour: experimental evidence from the bumblebee Bombus veteranus on calcareous grasslands. Biological Conservation 104 (3), 293-299.

Gustafson, E.J. (1998): Quantifying landscape spatial pattern: What is the state of the art? Ecosystems 1, 143-156.

Hanski, I. (1999): Habitat connectivity, habitat continuity and metapopulations in dynamic landscapes. Oikos 87, 209-219.

Harrison, S., Bruna, A. (1999): Habitat fragmentation and large-scale conversation: What do we know for sure? Ecography 22, 225-232.

Jedicke, E. (1994): Biotopverbund - Grundlagen und Maßnahmen einer neuen Naturschutzstrategie. Stuttgart.

Kareiva, P. , Wennergren, U. (1995): Connecting landscape patterns to ecosystem and population processes. Nature 373, 299-302.

Kearns, C.A., Inouye, D.W. \& Waser, N.M. (1998): Endangered mutualisms: the conversation of plant-pollinator interactions. Annual Review of Ecology and Systematics 2, 83-112.

Klein, A., Steffan-Dewenter, I., Tscharntke, T. (2003): Fruit set of Coffea arabica depends on the diversity of pollinating bees. Proceedings of the Royal Society of London, Series B 270, 955-961.

Kleyer, M., Kaule, G., Settele, J. (1996): Landscape fragmentation and landscape planning, with a focus of Germany. Kluwer academic Publisher,: 138-151. 
Kremen, C., Williams, N.M., Thorp, R.W. (2002): Crop pollination from wild bees at risk from agricultural intensification. Proceedings of the National Academy of Science of the United States of America 99 (26), 16812-16816.

Kruess, A. (2003): Effects of landscape context and habitat type on a plant-herbivoreparasitoid community. Ecography 26 (3), 283-290.

Menalled, F.D., Marino, P.C., Gage, S.H., Landis, D.A. (1999): Does agriculture landscape context affect parasitism and parasitoid diversity? Ecological Applications 9 (2), 634641.

Ostman, O. Ekbom, B., Berngtsson, J., Weibull, A.C., (2001a): Landscape complexity and farming parctice influence the condition of polyphagous carabid beetles. Ecology Applications 11, 480-488.

Ostman, O., Ekbom, B., Bengtsson, J. (2001b): Landscape heterogeneity and farming practice influence biological control. Basic and Applied Ecology 2 (4), 365-371.

O‘Toole, C. (1993): Diversity of wild bees and agroecosystems. Pages 169-196 in J. LaSalle and I.D. Gauld, editors. Hymenoptera and biodiversity. CAB International, Wallingford, UK.

PATCH-Analyst (2000): Utility for spatial analysis and attribute modelling of landscape patches. Version 2.2. Sustainable Forest Management Network (NCE) and Centre for Northern Forest Ecosystem Research (OMNR).

Rathcke, B. J., Jules, E. S. (1993): Habitat fragmentation and plant-pollinator interactions. Current Science 65, 273-77.

Richard, A.J. (2001): Does low biodiversity resulting from modern agricultural practice affect crop pollination and yield? Annals of Botany 88, 165-172.

Roschewitz, I., Thies, C., Tscharntke, T. (2003): Is landscape complexity and farm structure related to land-use intensity of annual crop fields? Agriculture, Ecosystems and Environment (submitted).

Roubik, D.W. (2002): Tropical agriculture - The value of bees to the coffee harvest. Nature $417,708-708$.

Saunders, D.A., Hobbs, R.J., Margules, C.R. (1991): Biological consequences of ecosystem fragmentation: a review; in „Conservation Biology“ 5(1), 18-31. 
Schulke, B. \& Waser, N. (2001): Long-distance pollinator flights and pollen dispersal between populations of Delphinium nuttallianum. Oecologica 27, 239-245.

Sokal, R.R., and Rohlf, F. (1995): Biometry. Freeman, New York, New York, USA.

STATGRAPHICS (2001): Statgraphics plus for Windows, version 5.1. Manugistics, Rockville, Maryland, USA

Statistisches Bundesamt (2002): Datenreport 2002. Zahlen und Fakten über die Bundesrepublik Deutschland, Bundeszentrale für Politische Bildung. Bonn, Germany.

Steffan-Dewenter (2003): Seed set of male-sterile and male-fertile oilseed rape (Brassica napus) in relation to pollinator density. Apidologie 34: 227-235.

Steffan-Dewenter, I., Münzenberg, U., Bürger, C., Thies, C., Tscharntke, T. (2002): Scaledependent effects of landscape context on three pollinator guilds. Ecology 83, 14211432.

Steffan-Dewenter, I., Münzenberg, U., Tscharntke, T. (2001): Pollination, seed-set und seed predation on a landscape scale. Proceedings of the Royal Society London, Series B 268, 1685-1690.

Steffan-Dewenter, I. \& Tscharntke, T. (1999): Effects of habitat isolation on pollinator communities and seed set. Oecologia 121, 432-440.

Steffan-Dewenter, I. \& Tscharntke, T. (1996): Profitieren Wildbienen oder Honigbienen von der Flächenstillegung in der Agrarlandschaft? Natur und Landschaft 71 (6), 255-261.

Thies, C., Steffan-Dewenter, I., Tscharntke, T. (2004): Plant pest-natural enemy interactions in spatio-temporally changing agricultural landscapes. (submitted).

Thies, C., Steffan-Dewenter, I., Tscharntke, T. (2003): Effects of landscape context on herbivory and parasitism at different spatial scales. OIKOS 101, 18-25.

Thies, C. \& Tscharntke, T. (1999): Landscape context and biological control in agroecosystems. Science 285, 893-895.

Tscharntke, T., Steffan-Dewenter, I., Kruess, A., Thies, T. (2002): Contribution of small habitats to conservation of insect communities of grassland-cropland landscapes. Ecological Applications 12: 354-363.

Weibull, A.C., Ostman, O., Granqvist, A. (2003): Species richness in agroecosystems: the effect of landscape, habitat and farm management. Biodiversity and Conservation 12 (7): 1335-1355. 
Westcott, L., Nelson, D. (2001): Canola pollination: an update. Bee World 82, 115-129.

Westrich, P. (1989): Die Wildbienen Baden-Württenbergs (2 Bde.). Ulmer Stuttgart.

Williams, I.H. (1996): Aspects of bee diversity and crop pollination in the European Union. Linnean Society Symposium Series - The Conservation of Bees 18, 63-80.

Williams, I.H. (1978): The pollination requirements of swede rape (Brassica napus L.) and of turnip rape (Brassica campestris L.), Journal of Agricultural Science (Camb.) 91, 343348.

Williams I.H., Free J.B. (1979): Compensation of oil-seed rape (Brassica napus L.) plants after damage to their flower buds and pods. The Journal of Agricultural Science 92, 53-59. 


\title{
Wind and bee pollination of oilseed rape in simple and complex landscapes
}

\begin{abstract}
Winter oilseed rape (Brassica napus L. ssp. oleifera (Metzg.), Brassicaceae) is the economically most important oilseed crop in temperate agricultural regions. We examined the relative importance of insect and wind pollination on oilseed rape in 15 study sites covering a gradient from structurally simple to structurally rich landscapes. In our study, open pollination (allows both wind and bee pollination) led to the highest seed set and was higher than the seed set provided by wind pollination. Observation of flower-visiting bees showed an increasing abundance of honey bees and wild bees with an increasing proportion of semi-natural habitats, but was not related to seed set. Our results suggest, that bee pollination in addition to wind pollination significantly enhanced seed set of winter oil seed rape.
\end{abstract}

\section{Key words}

Oilseed rape, pollination vectors, pollinator density

\section{INTRODUCTION}

Pollination is an important ecosystem function of great economic and ecological importance (Allen-Wardell et al. 1998, Kearns et al. 1998). Roughly, $80 \%$ of plant species and $75 \%$ of crop species are depending on pollination by insects (McGregor 1976). In contrast to wild plants, crops are particularly interesting because of high yield safety, high-quality fruits, even flowering time und even maturity. Successful pollination is essential to production of many agricultural crops. The preservation of this nature service is expected to depend on a great diversity and density of pollinators, i.e. native wild bees but also managed honey bees (Roubik 2002, Klein et al. 2003). The loss of managed honey bees (Bienefeld 1996) and the destruction of natural habitats in agricultural landscapes has led to a decrease in the bee density at a landscape level (Westrich 1989, O`Toole 1993, Steffan-Dewenter et al. 2002). 
Therefore, sufficient pollination services for crops are endangered (Corbet et al. 1991, AllenWerdell et al. 1998, Kremen et al. 2002, Klein et al. 2003)

The focal plant used in this study was winter oilseed rape (Brassica napus L. ssp. oleifera (Metzg.), Brassicaceae), the economically most important oilseed crop in temperate regions. In Germany in 2002, approximately 1.28 million hectare (11\% of the total agricultural area) were sown with oilseed rape (Statistisches Bundesamt 2002). As a result of the extensive cultivation, winter oil seed rape is one of the most important flower sources of honey bees in spring. Due to the high flower density (more than 10 million flowers per hectare) as well as the high nectar offer $(0.6 \mathrm{mg} / 24 \mathrm{hrs}$./flower) and high amount of pollen (1-1.3 $\mathrm{mg} /$ flower) (Hedtke 1998), oilseed rape attracts honey bees from large distances. The flowering phase of winter oil seed rape starts in April/May and lasts three to four weeks.

Oilseed rape is a predominantly self-pollinated crop with about one-third outcrossing (Becker et al. 1992). Accordingly, pollen transport by insects, wind or gravity as vectors appears to enhance yield (Free 1968, Williams 1978, Eisikowitch 1981, Westcott and Nelson 2001). Under field conditions, rates of cross-pollination of 5-55\% were found.

The pollination activity of honey bees in oil seed rape fields leads to a shorter flourishing period and the pods mature more uniformly. Generally, the seed set and the one thousand grain weight is higher with bee pollination than without bee pollination (Westcott and Nelson 2001). Langridge (1975) could demonstrate, that plants of oilseed rape with a hight bee density could produce more seed yield than plants without pollinators. However, other studies could not confirm this assumption. In fact, later cage studies on oilseed rape could not shown increasing yields in dependence of higher pollinator densities (Steffan-Dewenter 2003).

In this field study we analysed the effects of different pollination treatments (wind pollination and insect pollination) on the seed set of winter oil seed rape in relation to landscape context in 15 independent landscape units. Previous research results show that isolated plant populations may have a reduced seed set (Aizen \& Feinsinger 1994, Agren 1996, SteffanDewenter \& Tscharntke 1999, Cunningham 2000) and that structurally rich landscapes contain a higher abundance and diversity of wild bees (Steffan-Dewenter et al. 2002). Few studies have shown that high densities of pollinators enhance crop yields (Roubik 2002, Kremen et al. 2002, Steffan-Dewenter 2003).

In contrast to other studies we analysed the effect of the surrounding landscape and different ways of pollen transfer. We focused our study on two assumptions: (1) A combined effect of wind and insect pollination should influence yield components of oil seed rape positively. (2) The percentage of semi-natural habitats in the surrounding landscape should have an effect on 
the abundance of flower-visiting bees (honey bees and wild bees) and, therefore, enhances seed set on oil seed rape.

\section{MATERIAL AND METHODS}

\section{Experimental design}

The study was carried out in 2003 in an agricultural landscape in southern Lower Saxony around the city of Göttingen (Germany). We selected 15 landscapes covering a gradient from structurally simple to structurally rich landscapes. Each landscape contained a fallow as centre patch. For each site, different landscape metrics were calculated at 4 radii of $250 \mathrm{~m}$ to $1000 \mathrm{~m}$ (250m steps), representing a nested set of circular landscape sectors at four spatial scales. Landscape metrics were quantified using the Geographic Information System ARC \View 3.2 (ESRI Geoinformatik, Hannover, Germany).

We distinguished 27 habitat types which were grouped in annual and perennial habitat types (Bürger et al. 2003). For each habitat type we calculated the percentage area on each landscape level. The annual habitat types were all arable land. Hedgerows, fallows, grassland (grassland, orchard meadows and calcareous grasslands) and garden land were summarized to semi-natural habitats. Additionally, we calculated for each landscape level the MPAR (Mean Perimeter-Area-Ratio) as a measure of landscape complexity using the ARC $\backslash$ View -Extension PATCH Analyst 2.2.

Winter oilseed rape was used for the experiments. Four potted B. napus plants were placed on the fallows in the centre of each landscape sector. The plants were taken from a rape crop field which had been sown in the previous year and planted in pots of standardized garden soil (Fruhstorfer Einheitserde T25, Germany) in March 2003. The potted plants were placed in the centre of the fallow in each of the 15 landscapes between 02 and 08 April 2003. The distance between the plants was $1 \mathrm{~m}$. To prevent damage by rabbits or deer, the plants were fenced in with wire ( $4 \mathrm{~m} \times 4 \mathrm{~m}, 1.5 \mathrm{~m}$ high). Additionally, molluscicid was used against snail infestation. Depending on weather conditions, plants were watered every three to five days. Furthermore, mineral fertilizer was used to ensure a sufficient supply with nutrients. The advantage of this experimental design was the use of one oilseed rape variety, standardized garden soil, even amount of fertilizer and sufficient water supply, so that pollination and seed set could be studied in relation to the pollination potential of surrounding landscape independent from other local factors possibly influencing plant growth and reproduction. 


\section{Pollination experiment and seed set}

To examine the effect of pollination vectors, we compared five pollination treatments. (1) Open pollination was analysed with two potted plants, where all insects had access to flowers (insect pollination), but wind pollination was also possible. (2) Wind pollination and selfpollination was analysed in that insects were excluded by glued wire netting with $1 \mathrm{~cm}$ mesh size (one plant was completely caged with a in a cylindric cage: height $1.5 \mathrm{~m}$, diameter $60 \mathrm{~cm}$ ). (3) Flowers were hand pollinated with pollen from several other plants to measure the maximum fruit-set. Pollination by wind, insect or self-pollination were excluded due to for crispac-bags with micro holes (Baumann Saatzuchtbedarf - Waldenburg / Germany). (4 and 5) Insect but not wind pollination was excluded using cotton mesh gauze with $0.5-0.6 \mathrm{~mm}$ or $2 \mathrm{~mm}$ openings. For treatments (3),(4) and (5) only branches of the fourth potted plant could be used due to practical limitations. During the field experiment, no herbivores like the rape pollen beetle were observed, so that use of insecticide was not necessary. For all rape plants the number of pods, the number of seeds, seed weight, plant weight and total flower number were determined for each plant. Furthermore, the rates of the number of seeds to the number of flowers (= seeds / flower) as a measure of pollination capability was calculated.

\section{Flower-visitor observation}

Observations of flower visitors were done in 2003 (April - May) by visual counts. The four pots were observed simultaneously five times for $15 \mathrm{~min}$ and all flower-visiting insects were recorded. Bees were identified at genus level in the field and assigned to one of three pollinator groups, the honey bee (Apis mellifera), bumble bees (Bombus spp.) and other, mainly solitary wild bees (e.g. Andrenidae, Megachilidae). To obtain unbiased data, time of day was varied at a given study site for successive observation. The number of species and individuals were recorded in suitable weather conditions, i.e. at least $16^{\circ} \mathrm{C}, 70 \%$ sunshine, and low wind velocity.

\section{Data analysis}

The statistical analysis of the data were performed using Statgraphics plus 5.1 (Statgraphics 2001). All data were tested for normality and transformed when necessary. Arcsine-square root transformation was used to achieve normal distribution for percentages (Sokal and Rohlf 1995). We used one-way ANOVA (with Tukey HSD Intervals) to show differences between 
pollination treatments with regard to seed set and seed weight. Flower visitation data were correlated with yield components of oilseed rape to test for direct effects of different pollinator densities. In a second step we examined the effect of landscape context on fruit-set and yields of oilseed rape. We used four spatial scales ranging from $\varnothing 250 \mathrm{~m}$ to $\varnothing 1000 \mathrm{~m}$ to test for landscape-related patterns and to detect the spatial scale with the strongest effect (Steffan-Dewenter et al. 2002). Pollinator abundance per study site was the mean number of observed flower-visiting bees per $15 \mathrm{~min}$. Arithmetic means \pm one standard deviation are given in the text.

\section{RESULTS}

\section{Landscape context}

The dominant habitat type was cropland. For example, the mean percentage of annual habitats in a radius of $1000 \mathrm{~m}$ was $60.8 \pm 25.4$ (Table 1). The proportion of semi-natural habitats and the proportion of annual habitat types were negatively correlated at all spatial scales (linear regressions: $\mathrm{p}<0.01$ ). Due to this close intercorrelation, we focused our analysis on the proportion of semi-natural habitats as potential habitats for wild bees. No significant correlations existed between the three parameters proportion of semi-natural habitats, proportion of rapecrop fields and MPAR at any spatial scale (250-1000m radius).

Table 1: Habitat composition in the landscape sectors in Southern Lower Saxony, Germany.

\begin{tabular}{cccc}
\hline \hline Habitat type & Area( \%) & Minimum (\%) & Maximum (\%) \\
\hline Arable land & $60.82 \pm 25.4$ & 10.92 & 87.68 \\
Rape crop area & $7.57 \pm 5.42$ & 1.79 & 17.99 \\
Semi natural habitats & $19.68 \pm 13.33$ & 3.44 & 45.42 \\
Hedgerows & $1.37 \pm 1.64$ & 0.11 & 6.58 \\
Fallows & $3.24 \pm 2.52$ & 0.64 & 6.86 \\
Grassland & $13.36 \pm 10.5$ & 1.44 & 31.47 \\
Gardenland & $0.25 \pm 0.28$ & 0 & 0.89 \\
Urban park area & $0.23 \pm 0.38$ & 0 & 1.41 \\
& $11.31 \pm 14.98$ & 0 & 48.31 \\
Forests & $0.58 \pm 0.86$ & 0 & 3.28 \\
$\begin{array}{l}\text { Water areas } \\
\text { Settlement }\end{array}$ & $1.52 \pm 2.15$ & 0 & 7.97 \\
\hline $\begin{array}{l}\text { Note: Means } \pm \text { 1 SD, minimum and maximum are given for n= } 15 \text { study sites (Results are given } \\
\text { for 1000m radius) }\end{array}$ & &
\end{tabular}




\section{Flower visiting insects}

A total of 403 flower-visiting insects including bees was observed in the field in 2003. Flower-visitors were separated into honey bees, bumble bees and solitary wild bees and a group of non-hymenopteran insects, mainly hover flies and butterflies. In all 15 landscapes all flower-visitor groups were found. The mean number of observed flower-visiting insects (observed within $75 \mathrm{~min}$; table 2) was $6.72 \pm 2.2$ individuals per $15 \mathrm{~min}$. Within the group of flower-visiting bees, solitary wild bees (37.6\%) were more abundant than bumble bees $(32.1$ $\%)$ and honey bees (30.3\%).

Table 2. Observed individuals (per 75min) of all flower visiting insects, separated into honey bees, wild bees (solitary wild bees and bumble bees) and other flower visiting insects in 2003.

\begin{tabular}{lccc}
\hline \hline Species group & Mean $\pm \mathbf{1 ~ S D}$ & Minimum & Maximum \\
\hline Honey bees & $4.4 \pm 2.41$ & 1 & 9 \\
Solitary wild bees & $5.47 \pm 2.42$ & 2 & 8 \\
Bumble bees & $4.67 \pm 2.99$ & 0 & 10 \\
Other insects & $12.33 \pm 4,56$ & 5 & 21 \\
\hline
\end{tabular}

Note: Means $\pm 1 \mathrm{SD}$, minimum and maximum are given for 15 study sites.

The total abundance of all flower-visiting bees and different pollinator guilds significantly increased with the percentage of semi-natural habitats in the surrounding landscape over all spatial scales from $250 \mathrm{~m}$ (e.g. for total abundance of bees, Figure 1) to $1000 \mathrm{~m}$. The percentage of rapecrop fields und MPAR (Mean-Perimeter-Area-Ratio)was not related to the abundance of flower-visiting insects $(\mathrm{p}>0.05)$.

\section{Seed set on oil seed rape}

Generally, the results indicate significant differences between the different pollination treatments (Figure 2). With regard to seed set (seeds per flower), we found an increasing number of seeds per flower with increasing pollination intensity. A larger mesh size (gauze I $<$ gauze II < cage) and expected increasing pollen permeability led to a higher seed set by wind pollination (Figure 2). The effectiveness of hand pollination was lower than the value of the open pollination treatment, but differences were not significant. The highest number of seeds per flower were found for the open pollination treatment indicating that insect 
pollination increased seed set compared to the cage treatment with only wind pollination. However, on a landscape level our expectation that a higher abundance of flower-visiting bees on open-pollinated plants would result in higher seed set per flower could not be confirmed. The number of seeds per flower was neither directly related to the abundance of flowervisiting bees nor indirectly to the percentage of semi-natural habitats in the surrounding landscape at any spatial scale $(p>0.05)$. Similarly, the assumption that landscapes with a high proportion of rape fields facilitate wind pollination and thus result in an increasing seed set could not be confirmed $(\mathrm{p}>0.05)$.

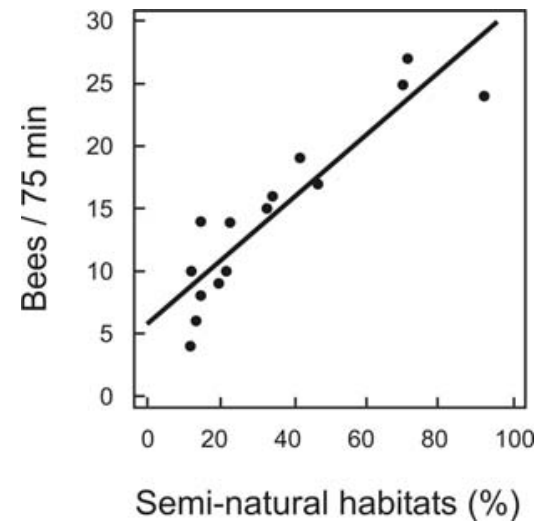

Figure 1: Relationship between the arc$\sin \sqrt{ }$ p-trasnfered percentage of seminatural habitats (within a radius of $250 \mathrm{~m}$ ) and the abundance of flowervisiting bees on open-flowering Brassica napus; $\mathrm{Y}=5.8105+$ $0.252871 X, \underline{\mathrm{F}}=62.12, \underline{\mathrm{P}}<0.01, \underline{\mathrm{R}^{2}}=$ 82.7).

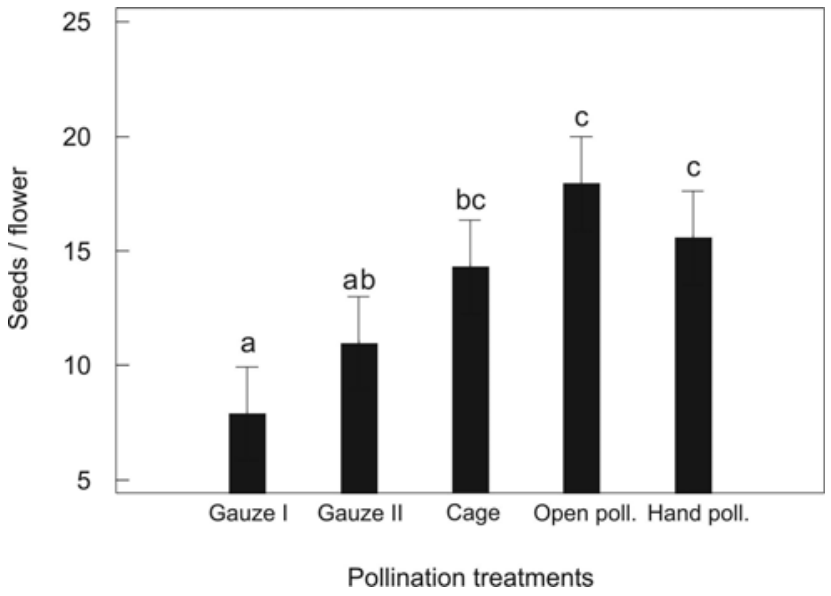

Figure 2: Seed set of Brassica napus in dependence of pollination treatment. Arithmetic means and Tukey HSD intervals are given. Different letters show significant differences $(\mathrm{p}<0.05)$ between experiments $(F=11.48, \mathrm{P}<0.001)$;

Wind pollination: a) gauze $I$ and b) gauze $I I=$ cotton mesh gauze with (a) 0.5 - $0.6 \mathrm{~mm}$ and (b) $2 \mathrm{~mm}$ openings, cage = glued wire netting (1cm mesh size) Insects and wind pollination: open pollination Control: hand pollination (pollination by wind , insetst or self-pollination was excluded) 
Table 3. Yield components of oilseed rape depending on different pollination vectors in 2003

\begin{tabular}{|c|c|c|c|c|}
\hline Year & Factor & Mean $\pm 1 S D$ & Minimum & Maximum \\
\hline \multirow{6}{*}{ Open pollination } & Pods & $246.2 \pm 83.98$ & 154 & 425 \\
\hline & Stalks & $15.07 \pm 6.46$ & 5 & 27 \\
\hline & Number of seeds & $4805.07 \pm 2122.06$ & 2687 & 9555 \\
\hline & Seed weight (g) & $15.23 \pm 5.73$ & 7.08 & 25.57 \\
\hline & Plant weight (g) & $33.49 \pm 16.25$ & 17.72 & 77.14 \\
\hline & Seeds / flower & $17.93 \pm 2.7$ & 13.04 & 21.82 \\
\hline \multirow{6}{*}{ Wind pollination } & Pods & $241.33 \pm 71.05$ & 122 & 367 \\
\hline & Stalks & $26 \pm 9.55$ & 14 & 38 \\
\hline & Number of seeds & $3933.8 \pm 1579.6$ & 1784 & 6923 \\
\hline & Seed weight (g) & $17.01 \pm 7.49$ & 6.82 & 31.84 \\
\hline & Plant weight (g) & $29.07 \pm 6.86$ & 14.06 & 37.47 \\
\hline & Seeds / flower & $14.3 \pm 2.71^{\circ}$ & 8.35 & 18.17 \\
\hline \multirow{6}{*}{ Hand pollination } & Pods & $26.47 \pm 14.16$ & 7 & 60 \\
\hline & Stalks & $0.8 \pm 0.68$ & 0 & 2 \\
\hline & Number of seeds & $442 \pm 277.88$ & 32 & 1034 \\
\hline & Seed weight (g) & $1.82 \pm 1.18$ & 0.17 & 4.42 \\
\hline & Plant weight (g) & $2.84 \pm 1.24$ & 1.42 & 5.29 \\
\hline & Seeds / flower & $15.57 \pm 4.72$ & 4.57 & 20.96 \\
\hline \multirow{6}{*}{ Gauze II } & Pods & $22.33 \pm 8.92$ & 10 & 42 \\
\hline & Stalks & $4.93 \pm 9.21$ & 1 & 11 \\
\hline & Number of seeds & $306.2 \pm 200.98$ & 35 & 815 \\
\hline & Seed weight (g) & $1.22 \pm 0.76$ & 0.19 & 2.79 \\
\hline & Plant weight (g) & $2.73 \pm 1.38$ & 1.03 & 4.83 \\
\hline & Seeds / flower & $10.97 \pm 4.82$ & 1.35 & 17.63 \\
\hline \multirow{6}{*}{ Gauze I } & Pods & $18.86 \pm 14.97$ & 2 & 60 \\
\hline & Stalks & $4.73 \pm 3.34$ & 0 & 12 \\
\hline & Number of seeds & $202.73 \pm 185.2$ & 13 & 699 \\
\hline & Seed weight (g) & $0.93 \pm 0.88$ & 0.06 & 0.89 \\
\hline & Plant weight (g) & $2.19 \pm 1.47$ & 0.86 & 6.47 \\
\hline & Seeds / flower & $7.91 \pm 4.45^{\circ}$ & 2.32 & 17 \\
\hline
\end{tabular}

Note: Means $\pm 1 \mathrm{SD}$, minimum and maximum are given for 15 study sites in 2003 for each pollination treatment; Gauze I: $2 \mathrm{~mm}$ openings, Gauze II: $0.5-0.6 \mathrm{~mm}$ openings; stalks= flowers which did not develop into pods; number of seeds = seeds found in pods; seed weight / plant weight $=$ dry weight $(\mathrm{g})$; seeds $/$ flower $=$ rates of the number of seeds to the number of flower

\section{DISCUSSION}

In our study we focused on pollination vectors and yield components of winter oil seed rape Brassica napus in differently structured landscapes. Pollen transfer in oilseed rape may take place in two different ways, by flower-visiting insects and by wind. The main finding of our 
study is that a combined effect of wind pollination and insect pollination could result in an increasing seed set of winter oil seed rape. However, number of seeds per flower was not influenced by the surrounding landscape, neither through a high percentage of semi-natural habitats nor through a high percentage of rape crop fields, although the density of flowervisiting bees was related to landscape context.

We assumed, that a higher percentage of semi-natural habitats provides a higher abundance and diversity of pollinators resulting in a higher seed set. In fact, we found very strong positive relationships between semi-natural habitats and the abundance of flower-visiting bees (honey bees and wild bees), so that landscapes with a high percentage of semi-natural habitats provided a higher abundance of flower-visiting bees. Other studies in the same region could confirm these results (Steffan-Dewenter et al. 2001, 2002). However, higher abundance of flower-visiting bees had no measurable effect on yield components of oil seed rape in a landscape context.

In our study we quantified the effects of different pollination vectors, mainly wind pollination and insect pollination. With our experimental design, a larger mesh size (gauze I > gauze II > cage) caused an increasing pollen transport by wind and lead to a higher seed set. Additionally, we found a higher seed set by open pollination (wind and insect pollination).

In the case of B. napus, potential benefit from insect pollinators is unclear. Several earlier studies provide evidence for a positive effect on yields of oilseed rape. Free (1968) reported that insect visitation would increase seed production and that $B$. napus plants caged with bees produced 25 percent more seeds than plants caged without bees. Von Rhein (1952) cited other workers who showed that bees caused 17.4 percent more seed per pod and 9.7 percent heavier seeds than were produced on plants not visited by bees. Louveaux and Verge (1952) reported a 50 percent increase in seeds per pod on plants growing near a large apiary as compared to plants caged to exclude bees. Langridge \& Goodmann (1975) could show an increasing seed set and seed set on oilseed rape in dependence on flower-visiting pollinators. However, these old results presumably are not quite comparable with the actual situation, because plant breeding greatly changed modern rape varieties with respect to shorter flourishing period and an uniform mature of pods and higher rates of self-pollination. Interestingly, our results suggest that even modern varieties still benefit from insect pollination. Additionally, insect pollination leads to earlier completion of flowering and more synchronous pod and seed ripening, thereby possibly increasing the weight of seed harvest (Williams et al. 1987; Westcott and Nelson, 2001). But such possible effects on yields were not measured in this study. 
In conclusion, the results indicate that open wind pollination combined with pollination by flower-visiting bees results in a higher seed set and may lead to an increasing yield of winter oil seed rape, although the effect were not measurable on a landscape scale. These results support results from other crops, such as coffee and watermelon, that pollinators can be essential for high and constant fruit set (Klein et al. 2003, Kremen et al. 2002). The pollination of crops by insects as a free nature service must be an essential intention of ecosystem management to save the biodiversity of plants and assure the yield of economically important crops.

\section{ACKNOLEDGEMENTS}

We greatly thank Carsten Thies for advice and helpful comments on the manuscript and the farmers for providing the field sites. This work was supported by the Scholarship Program of the German Federal Environmental Foundation.

\section{REFERENCES}

Agren, J. (1996): Population size, pollinator limitation, and seed set in the self-incompatible herb Lythrum salicaria. Ecology 77, 1779-1790.

Aizen, M.A., \& Feinsinger, P. (1994): Forest fragmentation, pollination and plant reproduction in a chaco dry forest. Argentinia. Ecology 75, 330-351.

Allen-Wardell, G.,Bernhardt, P., Bitner, R., Burquez, A., Buchmann, S., Cane, J., Cox, P.A., Dalton, V., Feinsinger, P., Ingram, M., Inouye, D., Jones, C.E., Kennedy, K., Kevan, P., Koopowitz, H., Medellin, R., Medellin-Morales, S., Nabhan, G.P., Pavlik, B.,Tepedino, V., Torchio, P., Walker, S. (1998): The potential consequences of pollinator declines on the conservation of biodiversity and stability of food crop fields. Conservation Biology 12, 1-11.

Becker, H.C., Damgaard, C., Karlsson, B. (1992): Environmental variation for rate on rapeseed (Brassica napus). Theor. Appl. Genet 84: 303-306.

Bienefeld, K. (1996): Die Bedeutung der Bienenhaltung in Deutschland. Deutsches Bienenjournal 5, 14-18. 
Bürger, C., Steffan-Dewenter, I., Tscharntke, T. (2003): Possible effects of landscape context and pollinator densities on yield of oilseed rape. Agriculture, Ecosystems and Environment (submitted).

Cunningham, S. (2000) Depressed pollination in habitat fragments causes low seed set. Proceedings of the Royal Society of London Series B 267, 1149-1152.

Eisikowitch, D. (1981): Some aspects of pollination of oil-seed rape (Brassica napus L.). Journal of Agricultural Science (Camb) 96: 321-326.

Free, J. B., and Nuttall, P. M. (1968): The pollination of oilseed rape (Brassica napus) and the behaviour of bees on the crop. Jour. Agr. Sci. (Cambridge) 71: 91-94.

Hedtke, C. (1998) Blütenökologische Untersuchungen an herbizidresistentem Raps (Brassica napus). Zwischenbericht zum Gutachten "Ökologische Auswirkungen der Einführung der Herbizidresistenz (HR)-Technik bei Raps und Mais": 30-33; 64-83.

Kearns, C.A., Inouye, D.W. \& Waser, N.M. (1998): Endangered mutualisms: the conversation of plant-pollinator interactions. Annual Review of Ecology and Systematics 2, 83-112.

Klein, A., Steffan-Dewenter, I., Tscharntke, T. (2003): Seed set of Coffea arabica depends on the diversity of pollinating bees. Proceedings of the Royal Society of London, Series B 270, 955-961.

Kremen, C., Williams, N.M., Thorp, R.W. (2002): Crop pollination from wild bees at risk from agricultural intensification. Proceedings of the National Academy of Science of the United States of America 99 (26), 16812-16816.

Langridge, D. F. \& R. D. Goodman (1975): A study on pollination of oilseed rape (Brassica campestris). Australian Journal of Experimental Agriculture and Animal Husbandry 15(73): 285-288.

Louveaux, J. and Verge, J. (1952): Researches on the pollination of winter rape. Apiculteur 96 (Sect. Sci.): 15-18.

McGregor, S. E. (1976): Insect pollination of cultivated crop plants. Agricultural handbook, US Department of Agriculture, No. 46.

O‘Toole, C. (1993): Diversity of wild bees and agroecosystems. Pages 169-196 in J. LaSalle and I.D. Gauld, editors. Hymenoptera and biodiversity. CAB International, Wallingford, UK.

Rhein, W. von (1952): Results of training bees by scent during the 1952 rape flow. Hess. Biene 88(8): 192-194, (9): 218-220. 
Roubik, D.W. (2002): Tropical agriculture - The value of bees to the coffee harvest. Nature 417, 708-708.

Statistisches Bundesamt (2002): Datenreport 2002. Zahlen und Fakten über die Bundesrepublik Deutschland, Bundeszentrale für Politische Bildung, Bonn, Germany.

Steffan-Dewenter, I. (2003): Seed set of male-sterile and male-fertile oilseed rape (Brassica napus) in relation to pollinator density. Apidologie 34: 227-235.

Steffan-Dewenter, I., Münzenberg, U., Buerger, C., Thies, C., Tscharntke, T. (2002): Scaledependent effects of landscape structure on three pollinator guilds. Ecology 83, 14211432.

Steffan-Dewenter, I., Münzenberg, U., Tscharntke, T. (2001): Pollination, seed-set und seed predation on a landscape scale. Proceedings of the Royal Society London, Series B 268, 1685-1690.

Steffan-Dewenter, I. \& Tscharntke, T. (1999): Effects of habitat isolation on pollinator communities and seed set. Oecologia 121, 432-440.

Sokal, R.R., and Rohlf, F. (1995): Biometry. Freeman, New York, New York, USA..

Thies C \& Tscharntke T (1999): Landscape structure and biological control in agroecosystems. Science 285: 893-895.

Westcott, L., Nelson, D. (2001): Canola pollination: an update. Bee World 82: 115-129.

Westrich, P. (1989): Die Wildbienen Baden-Württenbergs (2 Bde.). Ulmer Stuttgart.

Williams, I.H. (1978): The pollination requirements of swede rape (Brassica napus L.) and of turnip rape (Brassica campestris L.). Journal of Agricultural Science (Camb) 91: 343348.

Williams I.H., Martin A.P., White R.P. (1987) The effect of insect pollination on plant development and seed production in winter oil-seed rape (Brassica napus L.). J. Agric. Sci. (Camb.) 109: 135-139. 


\section{Summary}

Pollination is one of the most important processes in terrestrial ecosystems. This free nature service depends on a homogeneous distribution and sufficient density of flower-visiting insects, mainly wild bees and managed honey bees. Habitat destruction and habitat fragmentation and intensive land-use led to species loss on multiple trophic levels.

The aim of this work was to answer the question whether pollination is still sufficiently ensured by wild bees and honey bees in intensively managed agricultural landscapes. For this, it was necessary to quantify local honey bee abundance (chapter 2) and wild bee species composition and density in relation to landscape structure at different spatial scales (chapter 3). Thus it was tested, how solitary wild bees, social bumble bees and honey bees interact with the surrounding landscape (chapter 4). Furthermore, the influence of possible pollination limitation due to low densities of flower-visiting bees on yield of oilseed rape was studied in dependence of the surrounding landscape (chapter 5). Finally, the effect of different pollination vectors on oilseed rape was measured to quantify the relative importance of bee pollination and wind pollination for fruit set (chapter 6).

In a first approach, the spatial distribution and density of managed honey bees was measured, using Geographical Information Systems, for the district of Göttingen (Germany). In Germany, in a period of twelve years $(1989$ - 2000), the total number of managed honey bees decreased by $26 \%$ representing a loss of about 260.000 honey bee locations. Bee diseases and the high percentage of old beekeepers led to this situation. In cooperation with local beekeeper organizations, the location of each apiary in the district of Göttingen (Germany) was recorded. Conspicuously, the majority of honey bee locations was nearby villages or settlement areas. In 2002, a total number of 255 honey bee locations was recorded. Therefore, with regard to the mean foraging distance of honey bees $(1.5 \mathrm{~km}), 30 \%$ of the agricultural area were not sufficiently equipped with honey bees. In order to estimate the future change in local honey bee densities for the district of Göttingen in a period of 20 years, two scenarios were developed with different declines of $1.4 \%$ (scenario 1) and $2 \%$ (scenario 2) of apiary reduction per year. In scenario $1,38 \%$ of the agricultural area were not sufficiently supplied. In scenario 2 , the loss of agriculture area with potentially low honey bee densities increases up to $56 \%$. In conclusion, the current situation of beekeeping in the district of Göttingen has reached a critical level. The conservation of wild pollinator and the support of beekeeping must be a central topic to ensure pollination services for agricultural crops. 
In a second approach, the effects of landscape context and the influence of the percentage of semi-natural habitats at twelve spatial scales (radius $250-3000 \mathrm{~m}$ ) on species composition of trap-nesting wild bee communities were analysed in 18 landscapes sectors representing a gradient of structurally poor to structurally rich landscapes. Each landscape sector contained a fallow and a rapecrop field as study sites. Wild bee communities were recorded using traps made of common reed. Altogether, 3237 reed nests containing 13726 brood cells of eight solitary bee species (Hymenoptera: Apidae) and eleven wasps species (Hymenoptera: Sphecidae, Eumeninae, Pompilidae) were found in the 18 different landscapes. The local abundance and diversity of bees did not differ between fallows and rapecrop fields. Furthermore, an increasing proportion of the semi-natural habitats in the surrounding landscape had no positive effect on species diversity at any spatial scale. In contrast, an increasing proportion of rapecrop fields influenced the number of brood cells per nest and the total nest number of Osmia rufa (Hymenoptera: Apidae) at small spatial scales. In conclusion, all studied agricultural landscapes only supported relatively low numbers of solitary bees and wasps.

In a third approach, the effects of landscape context on the distribution of flower-visiting bees (Hymenoptera: Apoidea) at multiple spatial scales were analysed. 15 landscape sectors were selected quantifying the percentage of semi-natural habitats and the diversity of habitat types at eight spatial scales (radius 250-3000 m). Species richness and abundance of solitary wild bees showed a close positive correlation with the percentage of semi-natural habitats at small scales up to $750 \mathrm{~m}$, whereas bumble bees and honey bees did not respond to landscape context at these scales. In contrast, honey bees were correlated with landscape context at large scales. The densities of flower-visiting honey bees even increased with decreasing proportion of semi-natural habitats at a radius of $3000 \mathrm{~m}$. We are not aware of any other empirical studies showing contrasting foraging patterns related to landscape context at different spatial scales. Consequently, local landscape destruction affects solitary wild bees more than social bees, possibly changing mutualistic plant-pollinator and competitive wild bee - honey bee interactions. Analysis at multiple spatial scales help to detect the relevant functional spatial scale for pollinator guilds with different foraging distances.

In a fourth approach it was tested, if an increasing diversity and density of flower-visiting bees may have positive effects on the yield of oilseed rape (Brassica napus L. ssp. oleifera (Metzg.), Brassicaceae). In a two-years study, species richness and density of flower-visitors on rapecrop fields in 17 differentially structured landscapes were record. To measure the influence of the surrounding landscape, the landscape context was quantified as the 
percentage of semi-natural habitats, the percentage of rapecrop fields and MPAR (Mean Perimeter-Area-Ratio) at twelve nested spatial scales (radius of landscape sectors, 250$3000 \mathrm{~m})$. In contrast to previous expectations no relationship between species richness and abundance of pollinators and landscape context was found. However, flower visitor observations indicated significantly increased seed set per flower with increasing honey bee densities, whereas the abundance of flower-visiting wild bees had no measurable effect on yields of oilseed rape. Bee visitation had no effect on real yield $\left(\mathrm{g} / \mathrm{m}^{2}\right)$, probably as a result of the high compensatory-growth ability of oilseed rape and variation in cultivation methods or local soil conditions between the landscapes. In contrast, rape yield was positively related to a higher percentage of rape crop fields in the surrounding landscape, possibly due to higher pollen densities in the air and enhanced wind pollination.

In a fifth approach, the relative importance of insect and wind pollination on oilseed rape was experimentally studied in 15 study sites covering a gradient from structurally simple to structurally rich landscapes. Winter oilseed rape (Brassica napus L.) is the economically most important oilseed crop in temperate agricultural regions. Open pollination (by both wind and bees) led to the highest seed set and was higher than the seed set of caged plant, where only wind pollination was possible. Observation of flower-visiting bees showed an increasing abundance of honey bees and wild bees with an increasing proportion of semi-natural habitats, but this was not related to seed set. These results suggest, that bee pollination in addition to wind pollination significantly enhanced seed set of winter oil seed rape.

Summarizing the five studies, species richness and abundance of solitary wild bees depends on landscape context and habitat composition. Species diversity and abundance of flowervisiting bees increase with higher percentage of semi-natural habitats in the surrounding landscape. Generally, habitat fragmentation and destruction of ecologically valuable habitats can cause decreasing bee diversity (solitary wild bees, social bumble bees and honey bees). Pollination as a free nature service depends on a high pollinator density and may result in a higher fruit set and yield thus confirming the economical importance of pollination. In conclusion, a further loss of pollinators must be avoided to protect most wild plant species and to ensure high yields of insect-pollinated cultivated plants. 


\section{Zusammenfassung}

Bestäubung - eine „Gratisleistung der Natur“ - ist einer der wichtigsten Prozesse terrestrischer Ökosysteme. Sie hängt sowohl von einer gleichmäßigen Verteilung als auch von einer ausreichenden Dichte blütenbesuchender Insekten ab. Solitäre Wildbienen, Hummeln und Honigbienen stellen hierbei die drei wichtigsten Bestäubergilden dar. Die Zerstörung und Fragmentierung wertvoller Habitate führt durch intensive Landnutzung zu Artenverlust und Artenarmut auf vielen trophischen Ebenen.

In dieser Arbeit stand die Frage im Vordergrund, inwieweit die Bestäubung durch Wild- und Honigbienen in unterschiedlich strukturierten Landschaften noch gewährleistet ist. Hierzu wurde die Abundanz und die Dichte von Honigbienen (Kapitel 2) und der Artenreichtum und die Dichte von Wildbienen in unterschiedlich strukturierten Landschaft erfasst (Kapitel 3). Da Wild- und Honigbienen unterschiedliche Sammelradien besitzen wurde in dieser Arbeit getestet, auf welchen räumlichen Skalen diese beiden Bestäubergruppen die Landschaftsumgebung wahrnehmen und mit ihr interagieren (Kapitel 4). Um Bestäubung effektiv zu quantifizieren, wurde der Einfluss blütenbesuchender Bienen auf den Samenansatz von Winterraps (Brassica napus L. ssp. oleifera (Metzg.), Brassicaceae) in Abhängigkeit von der umgebenden Landschaft untersucht (Kapitel 5). Abschließend wurde die Bedeutung von Insektenbestäubung durch Bienen gegenüber Windbestäubung für den Samenertrag bei Winterraps analysiert (Kapitel 6).

Im ersten Abschnitt wurde mit Hilfe Geographischer Informationssysteme die räumliche Verteilung und Dichte von imkerlich genutzten Honigbienen erfasst. In einem Zeitraum von 12 Jahren (1989 - 2000) nahm in Deutschland die Zahl an Honigbienenvölkern um circa 260.000 ab. Das entspricht einem Rückgang von etwa 26\%. Vermehrt auftretende Bienenkrankheiten und eine Überalterung der Imkerschaft sind hier als Hauptursachen zu nennen. In Zusammenarbeit mit lokalen Imkervereinen wurde für den Landkreis Göttingen ein Imkereikataster zur Registrierung aller Bienenstände entwickelt. Im Jahr 2002 konnten für diesen Landkreis insgesamt 255 Bienenstände erfasst werden. Honigbienen besitzen einen mittleren Aktions- und Sammelradius von ungefähr 1,5 km. Angesichts dieser Tatsache, sind im Landkreis Göttingen schon im Jahr 2002 30\% der Agrarfläche mit Honigbienen unterversorgt. Zur Abschätzung der zukünftigen Situation in 20 Jahren, wurden zwei Szenarien mit unterschiedlichen Rückgangsquoten entwickelt. Bei einem jährlichen Rückgang an Bienenständen von 1,4\% würden im Jahr 2020 38\% der Agrarfläche mit Honigbienen 
unterversorgt sein (Szenario 1). Bei einem jährlichen Rückgang von 2\% würde sich die mit Honigbienen unterversorgte Agrarfläche auf 56\% erhöhen (Szenario 2). Aufgrund der gegenwärtigen Situation, hat die Imkerei im Landkreis Göttingen schon jetzt einen kritischen Schwellenwert erreicht. Demzufolge muss die Förderung und der Schutz der Imkerei ein zentrales Thema des Naturschutzes sein.

Im zweiten Abschnitt wurde der Einfluss von Landschaftsstruktur auf Wildbienenlebensgemeinschaften in 18 unterschiedlich strukturierten Landschaften auf verschiedenen räumlichen Skalen (Radius: 250m - 3000m) untersucht. In jedem Landschaftsausschnitt wurden auf einer Brache und einem Rapsfeld Nisthilfen ausgebracht, um die Wildbienenlebensgemeinschaften zu erfassen. Ingesamt wurden in allen 18 Landschaften 3237 Nester mit 13726 Brutzellen von acht solitären Wildbienenarten (Hymenoptera: Apidae) und elf Wespenarten (Hymenoptera: Sphecidae, Eumeninae, Pompilidae) gefunden. Es gab keine Unterschiede in der Abundanz und Diversität zwischen Brache und Rapsfeld. Der Anteil naturnaher Habitate in der umgebenden Landschaft hatte keinen signifikanten Einfluss auf Artendiversität und Abundanz von Wildbienen. Im Gegensatz dazu nahm mit steigendem Rapsanteil auf kleiner räumlichen Skala die Anzahl Nester von Osmia rufa (Hymenoptera: Apidae) zu und die Anzahl Brutzellen pro Nest ab. Schlussfolgernd konnte festgestellt werden, dass intensiv bewirtschaftete Agrarlandschaften nur wenige Arten - vor allem Generalisten - beherbergen.

Im dritten Abschnitt wurde der Einfluss von Landschaftsstruktur auf die Verteilung blütenbesuchender Bienen (Hymenoptera: Apoidea) auf verschiedenen räumlichen Skalen untersucht. In 15 verschiedenen Landschaftsausschnitten wurde die Habitattypendiversität und der Anteil naturnaher Habitate auch acht räumlichen Skalen (Radius: 250m - 3000m) ermittelt. Mit zunehmendem Anteil naturnaher Habitate stieg der Artenreichtum und die Abundanz solitärer Wildbienen, wobei die Abundanz von Honigbienen abnahm. Diese Zusammenhänge waren für Wildbienen auf kleinen räumlichen Skalen (bis 750m) und für Honigbienen auf großen räumlichen Skalen (3000m) am stärksten. Diese Skaleneffekte lassen vermuten, dass ein Landschaftswandel solitäre Wildbienen in weitaus höherem Maße beeinflusst als soziale Bienen (Hummeln und Honigbienen).

Im vierten Abschnitt wurde der Einfluss von Landschaftsstruktur, Diversität und Dichte blütenbesuchender Bienen auf den Ertrag von Winterraps untersucht. In einer Zwei-JahresStudie wurde in 17 unterschiedlich strukturierten Landschaften die Diversität und Dichte blütenbesuchender Bienen in Rapsfeldern erfasst. Die umgebende Landschaft wurde durch 
den Anteil naturnaher Habitate, den Anteil Rapsfelder und den MPAR (Mean-PerimeterArea-Ratio) auf zwölf räumlichen Skalen (Radius: 250m - 3000m) charakterisiert. Überraschenderweise bestand kein Zusammenhang zwischen den Landschaftsparametern und der Diversität und Dichte blütenbesuchender Bienen. Dabei konnte aber beobachtet werden, dass eine hohe Abundanz an Honigbienen einen positiven Einfluss auf den Samenansatz von Raps hat; hingegen hatte die Dichte von Wildbienen keinen Effekt auf den Samenansatz. Generell hatte der Blütenbesuch durch Bienen keinen Einfluss auf den Ertrag. Als mögliche Gründe hierfür sind die Kompensationsfähigkeit des Rapses und unterschiedliche Bewirtschaftungsmethoden auf den einzelnen Rapsfeldern zu nennen. Ertragssteigernd erwies sich jedoch ein erhöhter Anteil an Rapsfeldern, wodurch potentiell mehr Rapspollen zur Windbestäubung zur Verfügung stand.

Im fünften Abschnitt wurde die relative Bedeutung von Wind- und Bienenbestäubung auf Winterraps in 15 unterschiedlich strukturierten Landschaften untersucht. Winterraps ist eine der wichtigsten Ölsaaten in den gemäßigten Klimaten. Im Rahmen dieser Studie konnte festgestellt werden, dass offene Bestäubung (Wind- und Bienenbestäubung) zu einem höheren Samenansatz führen kann und somit höhere Befruchtungsraten erzielt als reine Windbestäubung. Obwohl ein positiver Zusammenhang zwischen blütenbesuchenden Bienen und dem Anteil naturnaher Habitate bestand, hatte die Landschaftsstruktur keinen Einfluss auf den Samenansatz. Dies gibt einen Hinweis darauf, dass Windbestäubung in Kombination mit Bienenbestäubung den Samenansatz von Raps verbessern kann.

Als Schlussfolgerung aus den fünf Arbeiten wird deutlich, dass die Diversität und Abundanz von solitären Wildbienen, Hummeln und Honigbienen von der Landschaftsstruktur und Habitatzusammensetzung abhängen, wobei die drei Bestäubergilden die umgebende Landschaft auf unterschiedlichen räumlichen Skalen wahrnehmen. Allgemein betrachtet steigen Diversität und Abundanz von blütenbesuchenden Bienen mit zunehmendem Anteil naturnaher Habitate an. Habitatfragmentierung und die Zerstörung ökologisch wertvoller Habitate können jedoch zu einem Rückgang der Bienendiversität führen, so dass hauptsächlich Generalisten in strukturarmen, ausgeräumten Landschaften anzutreffen sind. Bestäubung als „Gratisleistung der Natur“ hängt von einer ausreichenden Bestäuberdichte ab. Die Ergebnisse verdeutlichen, dass ein weiterer Verlust an Bienen als Bestäuber unbedingt vermieden werden sollte, damit der Erhalt von Kultur- und Wildpflanzen auch zukünftig noch gewährleistet ist. 


\section{Danksagung}

Herrn Prof. Dr. Teja Tscharntke danke ich sehr herzlich für die Bereitstellung des Themas, die gute Betreuung und Diskussionsbereitschaft. Herrn Prof. Dr. Stefan Vidal danke ich für die freundliche Übernahme des Korreferats. Bedanken möchte ich mich auch bei Herrn PD Dr. Ingolf Steffan-Dewenter für die gute Zusammenarbeit und Hilfsbereitschaft bei allen fachlichen Fragen, insbesondere bei der Bestimmung der Wildbienen. Insbesondere möchte ich mich auch bei Herrn Prof. Dr. Gerhard Gerold bedanken, der stets als Fachmann der Geographie mir helfend zur Seite stand.

Der Deutschen Bundesstiftung Umwelt (DBU) danke ich für die finanzielle Unterstützung des Projektes. Hierbei danke ich im Besonderen Frau Dr. H. Schlegel-Starmann, die mit Ihrer Unterstützung zum Gelingen dieser Arbeit beigetragen hat.

Besonders bedanken möchte ich mich bei allen MitarbeiterInnen des Fachgebiets Agrarökologie für die gute Arbeitsatmosphäre. Dr. Carsten Thies, PD Dr. Andreas Kruess, Indra Roschewitz und Doreen Gabriel danke ich für zahlreiche fachliche Diskussionen und Unterstützung in verschiedensten Bereichen. Vor allem Anne Le Mellec danke ich für die lustigen Stunden im GIS-Labor und Friedrich Sundmacher für die computerfachlichen Gespräche. Hella Grabe, Susanne Jahn, Susanne Schiele, Magdolena Weller und Mechthild Rittmeier für die Unterstützung bei technischen Problemen. An dieser Stelle möchte ich mich auch bei Dr. Claus Döring bedanken, der mich schon früh in die Methodik der GI-Systeme eingearbeitet hat.

Bedanken möchte ich mich bei den Landwirten, die mir die Durchführung meiner Experimente auf ihren Ländereien stets gestatteten und sehr an den Belangen der Agrarökologie interessiert waren.

Schließlich möchte ich mich für die uneingeschränkte Unterstützung meiner ganzen Familie bedanken, meinen Eltern, die stets an mich glaubten, meinen Geschwistern, die immer an Neuigkeiten meiner Arbeit interessiert waren und meinen guten Freunden, die in dieser Zeit immer zu mir gestanden haben. Letztendlich bedanke ich mich bei allen Bekannten, die diese Arbeit mit großem Interesse verfolgten und so stets motivierend waren. 


\section{Publikationen}

Bürger, C., Steffan-Dewenter, I., Tscharntke, T. (2004): Species richness of trap-nesting bees and wasps on fallows and oilseed rape fields in a gradient of landscapes complexity (submitted)

Bürger, C., Steffan-Dewenter, I., Tscharntke, T. (2004): Wind and bee pollination of oilseed rape in simple and complex landscapes (submitted)

Bürger, C., Steffan-Dewenter, I., Tscharntke, T. (2004): Possible effects of pollinator densities and landscape context on yield of oilseed rape. (submitted)

Bürger, C. (2004): Ist die Bestäubung in Zukunft noch gesichert? Deutsches Bienen Journal (im Druck)

Steffan-Dewenter, I., Münzenberg, U., Bürger, C., Thies, C., Tscharntke, T. (2002): Scaledependent effects of landscape structure on three pollinator guilds. Ecology 83, 1421 1432

Tscharntke, T., Bürger, C., Eber, S., Gabriel, D., Grabe, H., Grönmeier, M., Holzschuh, A., Jahn,S., Klein, A.-M., Klipfel, S., Kluth, S., Krauss, J., Kruess A., Lehmann, K., Poveda, K.,Roschewitz, I., Schiele, S., Schmidt, M., Schulze, C., Steffan-Dewenter, I., Sundmacher, F., Thies, C., Veddeler, D., Westphal, C. (2002): Wenn der Räuber seinen Feind verliert. Wissenschaftsmagazin der Georg-August-Universität Göttingen 1, 40-46. 


\section{Lebenslauf}

Name: $\quad$ Christof Bürger (international: Buerger)

Geburtstag und Ort: $\quad 30.01 .1973$ in Hildesheim, Deutschland

$2000-2004$

Promotion im Fachgebiet Agrarökologie der Universität Göttingen bei Prof. Dr. Teja Tscharntke. Gefördert von der Deutschen Bundesstiftung Umwelt (DBU)

Mai 2000

Diplomarbeit an der Georg-August Universität Göttingen zum Thema "GIS-gestützte Landschaftsstrukturanalyse und die Verbreitungsmuster von Wildbienen-Lebensgemeinschaften“, angefertigt am Geographischen Institut der Universität Göttingen (unveröffentlicht) bei Prof. Dr. G. Gerold

$1993-2000$

Diplom-Studium Geographie, Nebenfächer Botanik, Geologie und Naturschutz an der Universität Göttingen

$1992-1993$

Zivildienst (18 Monate)

Mai 1992

Abschluss der Allgemeinen Hochschulreife am Bischöflichen Gymnasium Josephinum in Hildesheim 